\title{
Family Choice in Education: A Model State System For Vouchers ${ }^{\dagger}$
}

\author{
John E. Coons* \\ Stephen D. Sugarman**
}

\section{TABLE OF CONTENTS}

FOREWORD

I. A Prologue to the Statute

A. Development

B. Family Grant Systems Distinguished

C. Outline of the Model Mechanism

1. An Educational Market

2. The Statutory Ceiling

3. Classification, Administration and Funding of Schools

4. Mechanics of the Market Mechanism

D. Predicting the Consequences

1. Neutralization of the Effects of Varying Wealth

2. Vesting Decisional Power in the Family Unit

3. Efficiency

4. Accountability

$\dagger$ This Article will soon appear as a monograph published by the Institute for Governmental Studies, University of California, Berkeley.

The authors have had the assistance and encouragement of many persons. Charles S. Benson, William H. Clune III, James S. Coleman, Stephen Goldstein, Frank I. Goodman, James Guthrie, Henry M. Levin, Frank I. Michelman, Robert M. O'Neil and Joln Simon each played a different, but lielpful, part. Professor Benson's patient job of mine detcction with garbled manuscripts remains one of the true imtellectual works of mercy. The other is the constant input of our sometime collaborator, William H. Clune III, who may well have invented "family power cqualizing." None of us now recalls either the moment of conception nor the identity of the father. Critics may find the metaplior appropriate.

The heroic work of collecting, organizing, and calculating the economic data and then writing the several early drafts of part III fell mainly to Stanley Gibson of the San Francisco bar. Without lim, the effort to put the statute in a context of economic reality would have been impossible. Others who struggled nobly at lesser length with that intractable problen were Micliael Adams of the California and Alaska bars and Gordon Ohanesian of the second-year class at Boalt Hall. Professor Jack Osman of San Francisco State College lielped us over some of the more esoteric economic barriers. To all our thanks with the usual disclaimer of their responsibility for our blunders.

* Professor of Law, University of California, Berkeley. B.A. 1950, University of Minnesota, Duluth; J.D. 1953, Northwestern University.

* Member of the California Bar. B.A. 1964, J.D. 1967, Northwestern University. 
5. Independence of Spending from Local Tax Referenda ___ 338

6. Variety in Style and Content _.__ 338

7. Experimentation _... 338

8. Community Control _______________ 339

9. Racial Integration ___ 339

10. Compensatory Education ______________ 340

11. Political Feasibility _________ 340

E. A Contrasting Model _____________ 341

F. Pure and Mixed Power Equalizing Models ___ 344

G. Preliminary Comment to the FCEA _— 344

II. The FAMILY ChoIce IN EdUCATION ACT _- $\square 346$

Article 1. Definitions 346

Article 2. Repeal of Statutes ___ 346

Article 3. Application —_ 347

Article 4. Transinission of Authority From Districts

to Superintendent and Board _ـ 348

Article 5. Private Schools Not Affected

Article 6. Duty of Parents and Others Having

Care and Custody of a Child _ 352

Article 7. Responsibilities of the Superintendent with Respect to Schools in Categories

A through $\mathrm{H}$

Article 8. Powers and Responsibilities of the

Superintendent witlı Respect to Schools in

Article 9. Powers and Responsibilities of the

Superintendent with Respect to Schools in

Categories $\mathrm{E}$ through $\mathrm{H}$ (Private)

Article 10. Powers and Responsibilities of Schools

in Categories A through $\mathrm{H}$ Under this Act __ 372

Article 11. Powers and Responsiblities of Schools in Categories A through D (Public)

Article 12. Capital Improveinents and Borrowing by Schools in Categories A through D (Public) _ـ 382

Article 13. Certification, Authority, and Responsibilities of Scliools in Categories $\mathrm{E}$ through $\mathrm{H}$ (Private)

Article 14. Limitations Upon the Sources of Revenue for Schools Under this Act

Article 15. Insurance of Financial Institutions

Making Loans to Schools in Categories

$\mathrm{E}$ through $\mathrm{H}$ (Private)

Article 16. A Levy Upon the Income of Parents of

$\begin{array}{lll} & \text { Children Attending Schools Under this Act } & 396 \\ \text { Article 17. The Protection of Pupils' Privacy } & 400\end{array}$

Article 18. Notice, Hearing, and Review of 400

Administration Action

Article 19. Discipline of Students Misconduct

Article 20. Exclusion of Student for

Incapacity to Benefit

Article 21. Withholding Promotion for Failure to

Make Academic Progress ___ 403

III. ECONOMIC AND TAX ANALYSIS

A. Setting the Article 16 Tax Rates and the Article

11 and 13 Tuition Credit Levels

1. The Baselines: Setting the Amount of Tuition

Credit for $B$ and $F$ Schools

401 
2. The Baselines: Setting the Taxes for $B$ and $F$ Schools

3. Setting the Tuitions Credit Amounts for $A$ and $E, C$ and $G$ and

$D$ and $H$ Schools

4. Setting the Tax Rates for $A$ and $E$, $C$ and $G$ and $D$ and $H$ Schools

B. The Gross and Net Burden of the Property Tax

for Schools on California Families Projected to $1972-73$

1. Estimating the Average Percentage of Local Property Tax Used to Finance Elementary and Secondary Public Education

2. Estimating the Amount of School Taxes Paid Per Adjusted Gross Income Group

3. State and Federal Tax Offsets Considered

The Cost and Revenue Dimensions

429

1. Cost Evaluation 433

EPILOGUE

2. Revenue Evaluation

\section{FOREWORD}

$I^{\mathrm{B}}$

EDUCATIONAL SERVICES, like medical services, were provided mainly in the private sector, no one would be surprised to discover that poor people received a lower quality education than the rich. American schools, on the contrary, are largely to be found in the public sector, and ironically, the publicly financed and administered system of education deals shabbily with the poor. A guiding principle of public operation, however, is equal treatment of equals. If a set of families enters a state park to go hiking, that group would be shocked indeed to discover that the scenic trails were reserved for its richer members and that only barren and rocky paths were held open for the poor. Nevertheless, our public schools operate in such a discriminatory way. Those who doubt this assertion might advantageously walk through Benjamin Franklin High School in East Harlem and then through South Commack High School in Suffolk County, Long Island. If this is not convenient, any inner-city high school could be compared with any high school in a suburban community where average family income is above $\$ 14,000$.

It is not entirely clear, however, what equal treatment in education imples: not an equal number of dollars spent on each youth, surely, nor stark uniformity of program. In practical terms, equal treatment probably means that for any two young people of roughly similar aptitudes, interests, and abilities, there should be offered roughly similar opportunities in educational mstitutions. Thus, while it is not necessary to demand uniform treatment of every student, it is necessary to remove the influence of parental wealth on the quality of treatment received. This Article represents a long step forward in seeing precisely and in detail how to remove the deleterious influence of variations in household income on the quality of education received. 
The Article is about freedom of choice, too. It is absurd to say that people are uninterested im exercising choice in cducation. Note the care that rich families exert in selecting private schools and academies for their children. Moreover, the threat of losing choice to enroll children in racially segregated schools is tearing communities apart. But choice can strengthen educational experiences. Young people differ in their responses to the environment and atmosphere of a given school. What may stimulate one child to learn may absolutely deter another. While one of the functions of an educational system is to help people discover what their aptitudes, interests, and abihties really are, such discovery is aided by diversity of educational experience. There may be greater diversity of experience within a single school in a wellto-do suburban region than there is within a single ghetto school, but not much between schools in a given region. Suppose, for example, a lad of junior high school age says, "I think science may be what really interests me, so I would like to go to a school where the faculty and the students all sort of concentrate on science." $\mathrm{He}$ is asking not only for a focus in the curriculum but an atmosphere. He could not find such a school in the public system. Another student might be seriously interested in music or painting and might want a school which offered concentration of teacher talent in artistic fields. Another student might want a more varied curriculum and indeed might seek exactly the kind of school he is attending today. The point is that the existing educational system does not offer enough diversity anong schools either to help people discover what kinds of lives they want to live or to serve differences in the aptitudes and interests that are known to exist among all groups in our society.

What choices exist today? The rich can afford private education, and the private sector offers substantially greater diversity among institutions than does the public sector. Some of those who cannot afford private education can obtain access to a different school by moving their residence. This may be a high price, and in any event, there is not much diversity by type of institution within the public sector. The poor who cannot move have no choice. Some advocates of policy revision would concentrate on providing more clioice to the poor. Poor families would be offered voucliers entitling them to enroll their children in those particular scliools, private or public, that appealed to them. The authors of this Article are wise enough to see that substantially broadening the educational choices of the poor must be accompanied by increasing the options available to the middle class.

It is not immediately obvious that both the goals of removing the influence of household mcome on the quahity of educational opportunity and offering notably greater freedoin of choice in the selection of educational programs can be obtained. Tying these two objectives to- 
gether creates an incongruity-becoming more egalitarian and at the same time serving differences in consumer preferences more precisely. Traditionally, when a public program is attacked, as public education is now being attacked, on the grounds that it is distributing its services in a discriminatory manner, the response has been to make services more uniform-to reduce differences in what is offered to different groups of households.

The solution that is proposed in this Article is remarkably ingenious and deserves extremely careful study. Actually, the authors are treading a narrow path, and at the risk of being obvious it should be pointed out why the path is narrow. Until now it has been assumed that all choices im education that people want to make are good and socially helpful. Most might be, but perhaps some people would use their new options to undermine inajor national values. For example, soine might exercise the opportunity granted under the Family Choice in Education Act, (FCEA) to create a new type of elitist and white separatist institution. Much of the Act is concerned with this point. There are a number of provisions to forestall the possibility of this happening. Three of these are: the proscription of using income to build an endowment, the disallowance of parental supplements to stated tuition rates through extra fees paid directly from their household income, and random selection of students in cases where a given school is over-subscribed. The critics of the FCEA will undoubtedly contend that these controls are not sufficient. It may be pointed out for example that controls on teacher selection are modest and, therefore, a school could establish criteria which discouraged applications from the poor or the blacks. It might also be said that since the Act does not proscribe the coinpulsory wearing of uniforms by students, the poor could be discouraged by a school's estabhishing such a requirement.

Thus, the dilemma is presented: Controls are necessary, because otherwise too many people might make anti-social choices. On the other hand, the more comprehensive and detailed the controls becoine, the less chance there is of obtaming any real diversity in types of educational institutions. It is pointless to give people the right to choose unless diversity exists-stringent control of private schools, for example, with respect to the kinds of faculty they must hire would tend to negate alternatives which would otherwise be presented. The control problein is, then, the crux of the matter. We should be grateful to the authors for brimging us to the poimt where that issue can be seriously and meaningfully debated.

Charles S. Benson*

* Professor of Education, University of California, Berkeley. A.B. 1943, Princeton University; M.A. 1948, PhD. 1955, Columbia University. 
[I]ronically, the failure to construct a world-view commanding general assent was the great achievenient of the age. . . . The collision and interaction ... increased the variety, nuultiplied the potentialities, and raised the intellectual and moral energies of Europe to a new height.

W.H. McNeil $\dagger$

The clash of doctrines is not a disaster, it is an opportunity.

A.N. Whitehead:

\section{A Prologue to the Statute ${ }^{1}$}

The use of the family as a basic unit of decision making in publicly financed education has received sporadic consideration since Adam Smith. ${ }^{2}$ The popularity of the idea has waxed and waned in rhythm with the discontent over publicly administered systems offering limited options to parents and students. The concept has never been implemented in this country except for special purpose programs (such as those providing for the education of retarded children) in which public grants have permitted families to shop for schools.

Currently there is a rebirth of interest in family choice, and several systems for implementing it have been publicized in outline form. ${ }^{3}$ These modern systems all travel under the generic title "educational vouchers," but the differences among them are many and important. While some of these differences have been articulated, none of the proposals has yet been made sufficiently specific to permit thoroughly informed criticism. For this reason the level of the dialogue concerning vouchers has often been disappointing. The Family Choice in Education Act (FCEA) proposed in part II of this Article is intended to provide a basis for serious dialogue among policy makers and critics.

$\dagger$ THE RISE OF THE WeST 642 (1965).

$\neq$ SCIENCE AND THE MODERN WORLD.

1. Portions of part $I$ of the Article have been adapted from Coons, Recreating the Family's Role in Education, in 3 INEQUALITY IN EDUCATION 1 (Harvard Center for Law \& Educ. ed. 1970) and Coons, Clune \& Sugarman, Recreating the Family's Role in Education, in NEw MOdels For AMERICAN EduCATION 216 (J. Guthrie ed. 1970).

2. A. SMith, Wealth of Nations 342 (Great Books ed. 1952). The clearest early expression of the idea is J.S. MIIL, ON LIBERTY 156 (Regnery ed. 1955).

If the government would . . . require for every child a good education . . . [I]t unight leave to parents to obtain the education where and how they pleased, and content itself with helping to pay the school fees of the poorer classes of children, and defraying the entire school expenses of those who have no one else to pay for them.

3. Several of these suggestions are described in CENTER FOR THE STUDY of Public Policy, Educational Vouchers (1970) thereinafter cited as Educational VoUCHERS]. 
It embodies hundreds of highly specific answers to the relevant policy questions. Its provisions can serve as paradigms or punching bags according to the preferences of the particular critic. Of course, the objective here is more than heuristic; the act is a serious policy proposal for a substantial legislative experiment.

\section{A. Development}

It may be useful to outline some of the intellectual history of this model act which was first outlined in 1969.4 Its genesis is radically different from that of every other family choice scheme. The statute is an offspring of the lawyers' questing for a constitutional principle to purge public education of discrimination against poor districts and poor people. Historically the states' primary control over educational spending $\mathrm{m}$ public schools has been shared in a complex manner with local political units-typically school districts and counties. These units have been empowered to levy taxes upon local property and to spend locally whatever they raise. This balkanization of the states' tax resources produced the extreme variations in property taxes and in spending levels which recently have driven parents and taxpayers in poorer districts to the courts. ${ }^{5}$ Within the next year it is possible that the judiciary will have addressed itself to the basic constitutional questions which are involved-primarily, whether such systems satisfy the equal protection clause of the fourteenth amendment. The judicial outcoine is radically unpredictable. ${ }^{\circ}$

From the start the 1nost serious of many problems faced in the attempt to apply the fourteenth amendment to state systems of educational financing was the identification of a standard for judicial intervention that would leave intact the decentralized school apparatus which is so much a part of American tradition. Supporters of the status quo asserted that the case for equal education opportunity inevitably "demands the elimination of local governmental authority to choose the ways in which it will assess, collect, and expend its tax funds." In an effort to avoid any such threat to "subsidiarity" in education, a constitutional

4. Coons, Clune \& Sugarman, Educational Opportunity: A Workable Constitutional Test for State Financial Structures, 57 CAL.IF. L. REv. 305 (1969).

5. The state systems and the litigation are detailed in J. Coons, W. Clune \& S. Sugarman, Private Wealth and Public Education (1970) [hereinafter cited as Private Wealth and Public Education].

6. The issues are posed directly in Serrano v. Priest, 3 Cal. App. 3d 1110, 89 Cal. Rptr. 345 (2d Dist. 1970), now awaiting decision in the California supreme court, testing whether the state may relegate the financial support of public education to units (districts) of varying wealth. The case is likely to be appealed to the United States Supreme Court, whatever the outcome in California.

7. Kurland, Equal Educational Opportunity: The Limits of Constitutional Jurisprudence Undefined, 35 U. Cm. L. REv. 583, 589 (1968).

8. This is the principle that "government should ordinarily leave decision making 
formula was sought which would be effective in promoting equal opportunity but which would legitimate the continued use of small units to make basic decisions, mcluding decisions concerning the level of spending per pupil. The proposition ultimately adopted by the authors is very simple: the quality of public education may not be a function of wealth other than the wealth of the state as a whole. ${ }^{0}$ This principle would make equality of opportunity and decentralized school government compatible - at least in the sense that a decentralized system is valid if the school districts are substantially equal in their economic power. Districts might choose to exercise that power differently from one another, but this in itself seemed inoffensive. ${ }^{10}$ Indeed, there is something positive to be said for local differences in school spending, if those differences are not based on wealth. ${ }^{11}$

What was lacking at this point was an existing model which could achieve uniformity of district capacity to spend for education. Such a system was, therefore, designed and labeled "power equalizing."12 It depends upon familiar devices such as subsidies, redistribution, and redrawing of districts. Its effect would be to make spending depend solely upon the district tax rate and not upon district wealth. Specific programs of power equalizing could take innumerable forms, some complex, some relatively simple, so long as the decision making units were left with the same economic power.

If school districts could be given economic parity, so could any other kind of sub-unit with taxable wealth or income; the potential role of the family thus became obvious. If it were desirable to do so, local political units could be eliminated altogether from public education. In their place the family could, in effect, become the school district for two crucial purposes: it could assign pupils to particular schools, and it could fix the level of "local" taxation and spending through its choice of rate under a variable self-selected tax on the family's imcome. Each level of that tax would trigger a different level of state-guaranteed educational spending for the family's children. Educational decisions requiring political consensus could be rendered exclusively at the state level; but, within a range of per-pupil spending legislatively estabhshed,

and administration to the smallest unit of society competent to handle them." Private Wealth and Public Education 14. $285-462$.

9. The legal argument for this position is somewhat more complex. See id. at

10. But see A. WiSe, Rich Schools, POOR Schools: The Promise of Equal EduCATIONAL OPPORTUNITY 146 (1968); Michelman, Foreword: On Protecting the Poor Through The Fourteenth Amendment, 83 HARv. L. REv. 7, 56-57 (1969).

11. The policy advantages of such diversity are explored in PRIVATE WEALTH AND Public Education 14-19, 202-03, 270-83.

12. See id. at 199-242; cf. id. at 243-83. 
the decisions fixing the number of public dollars available to a particular child for education could be made exclusively by the child's family. In essence this is the model structure which is elaborated in this Article. It is the unlikely but legitimate offspring of outrage over maldistribution of public education and property tax burdens.

\section{B. Family Grant Systems Distinguished}

Apparent similarities of such a "family power equalizing" model to the rash of family grant systems recently proposed should be carefully scrutinized. These other models have generally taken one of two forms. The first is the uniform grant, a device which would grossly disadvantage the children of poor families by insuring their isolation in schools charging no more than the amount of the grant. ${ }^{13}$ To support such a program would be to embrace in its most extreme form the very discrimination against the poor which first motivated the search for alternatives. The second and more recent form of family grant scheme would avoid this injustice by providing grants for the disadvantaged pupil that vary inversely in amount according to his family's income. ${ }^{14}$ However, these grants would be in amounts set for the child at some level of government, and thus would give the family itself no opportunity to affect the size of the voucher, whatever its own wishes in this respect may be.

The FCEA accepts the desirability of variable grants but rejects two of the policy commitınents of even these recent and more "liberal" schemes. First, the FCEA would eliminate rather than emphasize family wealth as an influence upon the size of the voucher. Second, the FCEA, within limits, would make the size of the voucher vary according to the judgment of the family itself rather than that of government alone. It is the only model giving the poor family choice concerning the level of spending. Moreover, it is the only model which requires the family to make some contribution out of its own wealth toward the voucher. There are other important differences that will appear; at this point it may be seen that, while many value cloices inform the provisions of the statute, two are fundamental:

(1) The quality of publicly financed education should not be a function of wealth-other than the wealth of the state as a whole.

(2) Above an adequate minimum expenditure per pupil required by law, families might fairly be permitted to choose among dollar levels of educational offering.

13. See, e.g., Friedinan, The Role of Government in Education, in Economics AND THE PUBLIC INTEREST (R. Solo ed. 1955).

14. See, e.g., Sizer \& Whitten, A Proposal for a Poor Children's Bill of Rights, 5 Psychology Today (1968). A recent refinement of this proposal is considered in the text accompanying notes 71-76 infra. 
The model aims, therefore, to eliminate-insofar as possible-the influence of wealth variation upon publicly financed education, while, at the same time locating in the family the responsibility and the freedoln not only to clroose among schools but also to fix its own order of preference between education and all the other opportunities for consumption that compete with education for the family dollar.

However, in addition to these two basic aims, there are at least nine related inajor purposes which the model is designed to advance: Efficiency in educational spending; accountability to consumers; independence of spending froin local tax referenda; variety in style and content of education; increased experimentation; community control; racial integration; compensatory education for the disadvantaged; and political feasibility. ${ }^{15}$ Consideration of the extent to which these specific nine purposes might be served by the proposed scheme will be reserved until the outline of the inechanisin has been described.

\section{Outline of the Model Mechanism}

The inodel has been designed in the form of an amendment to the Cahfornia system of school finance and governance. However, it is adaptable to any state, with modifications of varying magnitude being required. It is not suggested that the model is complete in every detail; for example, certain constitutional changes might be required in Cahfornia $^{16}$ and perliaps elsewhere. Moreover, although it is basically a state system, certain adaptations of the current federal aid prograins would also be necessary. ${ }^{17}$

\section{An Educational Market}

Basically, the model would create an educational market offering products (schools) at several distinct levels of per pupil cost. At each of these levels, proprietors-public and private (the system could be inade exclusively public or private)—would compete for the custom of

15. Other purposes will also be identified in the comments to the various statutory sections set forth in part II infra.

16. California constitutional provisions plausibly relevant are article IX, sections $3,3.1,3.3,5,6,8$, and article XIII, sections $1 \mathrm{c}, 21,24,25$. Only the last section, article XIII, section 25 , forbidding the lending of the state's credit, is clearly in conflict with the Model Act which in article 15 provides for state-guaranteed loans to private schools. The aid to rehigion sections of the constitution (article IX, section 8, and article XIII, section 24) also pose difficult issues. These were considered in drafting FCEA article 10 , section 1 , dealing with regulation of rehious schools. However, argument of these thorny problems is not the authors' present purpose. For a view of the question compatible with that of the authors see Choper, The Establishment Clause and Aid to Parochial Schools, 56 CALIF. L. REv. 260 (1968).

17. The federal programs assume the existence of traditional state structures. See, e.g., 20 U.S.C. \$§ 241a, 241c (Supp. V, 1970). 
buyers (parents) all of whom have been made substantially equal in their power to purchase admission. To establish that equality the model would condition access to any school upon an equivalence of economic sacrifice for every family choosing that school, irrespective of family income. Accordingly, each family's selection of a school from among schools of varying per pupil cost would represent also a choice among varying rates of a special tax to be levied upon the family's income; but the tax burden on families of different incomes choosing schools of the same per pupil cost would, in economic terms, be rendered equivalent by means of a progressive rate structure. ${ }^{18}$

For example, upon enrolling its children in an elementary school which receives-and is effectively limited in spending to-the statutory minimum tuition credit of $\$ 600$, a family with an income of $\$ 4,000$ would become subject to a tax of $\$ 16.50 .^{19}$ Access to a $\$ 1,500$ school would cost that same family $\$ 54.50$. Enrollinent in these same two schools by children of richer families would create correspondingly greater tax liabilities. For example, a $\$ 20,000$ income family would pay $\$ 440$ and $\$ 1,218$ for the respective schools. Not ouly would the tax be proportionatcly larger for the wealthier family; the rate would also be adjusted to account for diminishing marginal utility. ${ }^{20}$

\section{The Statutory Ceiling}

In absolute terms the family's yearly educational tax hability could range from $\$ 5$ for a welfare family up to the statutory ceiling of one and one half times the total tuition of the family's children; ${ }^{21}$ this ceiling would provide a mild advantage to the very wealthy family. For example, the tax liability of a family with an income of $\$ 100,000$ and with two children attending elementary schools enjoying the highest elementary tuition credit $(\$ 1,500)$ would be limited to $\$ 4,500$ instead of the $\$ 9,898$ that would be required by the rate alone $(\$ 610+7.6 \%$ of income above $\$ 12,000$ ). Of course, the net cost would be even lower because of federal tax deductions. ${ }^{22}$ Except for the very rich the total tax would not vary by the size of the family.

The question of imposing such a ceiling on the wealthy family's tax burden raises a vexing issue of principle. Given the ceiling provision, when a particular level of wealth is attained, the absolute dollar contribution ceases to grow. In our example of the two child family

18. This tax and its rates are provided for in Family Choice in Education Act art. 16, §§ 1-2 [the Act is hereinafter cited as FCEA].

19. Id. art. $16, \S 2$, table II; see id. art. 11 for an explanation of school spending categorizations.

20. See text accoinpanying note 135 infrá.

21. FCEA art. $16, \S 2$.

22. INT. REV. CODE of 1954, § 164(a)(3). 
using the $\$ 1,500$ school, a family incone of a million dollars would be taxed at the rate of $.375 \%$ while one of $\$ 12,000$ would pay $5.08 \%$. Obviously this violates the principle of equality of economic sacrifice. The justification for the departure is purely pragmatic; it is a concession designed to assure that the richest families would not automatically desert the systein for purely independent private schools. No one is likely to voluntarily pay $\$ 75,698$ for a $\$ 1,500$ education for two children. ${ }^{23}$ Although the number of fainilies wealthy enough to be above the breakeven line is very small, they should not be driven from the system for the sake of consistency.

A slightly different form of the system could be imagined which would permit somewhat higher exactions from the rich. This is the "preemptive" model in which all schools would be required to operate within the publicly financed structure. Althougli sucli a scheme might be constitutional if it were sufficiently tolerant of ideological differences, ${ }^{24}$ it would be likely to prove too confining for certain forms of experimentation and, in any event, for political reasons would be unlikely to include a fully progressive tax rate operating without a ceiling at all levels of wealtl.

\section{Classification, Administration, and Funding of Schools}

Schools within the system established by the FCEA are classified in two ways: A division is made between schools which are public (Categories " $A$ " through " $D$ ") and those which are private (Categories " $E$ " through " $\mathrm{H}$ "); and all scliools, public and private, are divided into eight per-pupil cost levels ${ }^{25}$ (four each for two levels of schooling which are roughly equivalent-tliough not identical-to kindergarten through grade eight and the ligh school grades respectively). As currently envisioned for California (nuch would depend upon the wealth of the particular state), the schools would be pernitted to spend the following amounts per pupil: ${ }^{26}$

23. The rate is $\$ 610$ plus $7.6 \%$ of income above $\$ 12,000$, or $\$ 610$ plus $\$ 75,088$. FCEA art. 16, § 2 .

24. Pierce v. Society of Sisters, 268 U.S. 510 (1925), can easily be limited to the holding that the state inay not forbid the parents' choice of a private school that complies with reasonable state regulation. Indeed, insofar as the case represents an application of substantive due process, it is probably no barrier at all. If the provisions of a preemptive FCEA were sufficiently flexible and generous to avoid any burden on first amendment rights, there would be little to fear from the Constitution. See Sherbert v. Verner, 374 U.S. 398 (1963). However, it is not at all clear that the legislature would be willing to give to fringe religious and political groups the freedom necessary to their sclools. This is another reason why systems such as that enbodied in the FCEA, if adopted, are unlikely to be preemptive.

25. FCEA art. $11, \S 1$, art. $13, \S 1$.

26. The basis for the particular spending figures is detailed in part III infra. 


$\begin{array}{lcccc} & \begin{array}{c}\text { A and E } \\ \text { Schools }\end{array} & \begin{array}{c}\text { B and F } \\ \text { Schools }\end{array} & \begin{array}{c}\text { C and G } \\ \text { Schools }\end{array} & \begin{array}{c}\mathrm{D} \text { and H } \\ \text { Schools }\end{array} \\ \begin{array}{l}\$ 1,200 \\ \text { K-8 (equivalent) }\end{array} & \$ 600 & \$ 900 & \$ 1,500 \\ \begin{array}{c}\$ \text { High School } \\ \text { (equivalent) }\end{array} & \$ 900 & \$ 1,200 & \$ 1,500 & \$ 1,800\end{array}$

Administrative authority over the public schools in the area affected by the system would be shared among a "chief administrator" of each school, the state superintendent who would appoint him, and the state board. ${ }^{27}$ County and district educational authorities in these areas would cease, ${ }^{28}$ but the job riglits of present employees of abolislied districts would be given substantial protection. ${ }^{29}$ The state superintendent and board would have authority through regulation to unify or decentralize administration of the public schools for some purposes, ${ }^{30}$ but the financial operation and support of these schools would be radically decentralized. ${ }^{31}$ The FCEA gives the public scliool authorities considerable flexibility in determining style and content of education, ${ }^{32}$ and private schools would qualify to enter the system by meeting roughly the mimimum statutory standards imposed upon public scliools. ${ }^{33}$ Each private scliool would decide for itself at which one of the four proposed levels of cost it would operate ${ }^{34}$ and this decision would also fix the rate of the family tax imposed on parents for attendance of their children at that school. ${ }^{35}$ For each public school that choice would be made by the state superintendent based largely upon demand in a particular area for each level of per pupil cost with its accompanying tax..$^{36}$ For every school-public and private-the superintendent would maintain a drawing account containing, for each student enrolled, the number of dollars appropriate to schools of that class. ${ }^{37}$ The dollars would be earmarked by student, and a pro-rated share would move with the student from scliool to school if he transferred during the year. ${ }^{38}$ The system thus skirts the church-state problems in private schools by treating the child as the recipient. ${ }^{39}$

27. FECA art. $8, \S \S 2,4$.

28. Id. art. $4, \S 1$.

29. Id. $\S \S 4 \& 5$.

30. Id. art. 8 .

31. Id. art. $12, \S 1$, art. $13, \S 4$, art. $14, \S \S 2-5$. This feature is explained in the text accompanying notes $46-49$ infra.

32. FCEA art. $8, \S 5$, art. $10, \S \S 11,12$; see id. art. $10, \S 2$.

33. Id. art. 10, §§ 11,12 , art. $13, \S 5$.

34. Id. art. 13, \& 2(2).

35. Id. art. $16, \S 2$, art. 17 .

36. Id. art. $8, \S \S 1,2$.

37. Id. art. 7, \& 2 .

38. Id. The same section provides for the necessary adjustment if the new school is in a different spending category.

39. Id. art. 10, \& 1 represents a further effort to diminish both the establishment and free exercise problems. 
The local property tax for education would cease..$^{40}$ The funding of the total system would no doubt would be based primarily on statewide sources, although the FCEA does not speak specifically to that question. ${ }^{41}$ The special family tax described above is designed principally as a vehicle for measuring and distinguishing family interest in education. Clearly it would not fund the bulk of the total cost of the system. This means that the cost of education would be broadly distributed but also that the primary beneficiaries would pay an additional cost representing in the aggregate a very rough estimate of the value of the purely private benefits.

\title{
4. Mechanics of the Market Mechanism
}

At a point in time well before the opening of sclool-January 15 is proposed-each fainily would select a particular school and alternates by weighing such factors as a school's cost category and other information concerning each school-for example, curriculum, test scores, religious affiliation-that the state superintendent would be required to supply each parent. ${ }^{42}$ All schools-public and private-within the limit of their preannounced capacity would be open to all children of appropriate age and grade ${ }^{43}$ (thus plausibily requiring certain protections against religious indoctrination for non-believers attending private rehigious schools). ${ }^{44}$ Transportation would be essential to such a systein, and would be supported by the state up to a reasonable distance to be fixed by regulation. ${ }^{45}$

Because of its commitment to the market mechanism, the model would financially isolate each school-public as well as private-limiting its income, with certain exceptions, to the amount fixed per pupil by statute for its spending category, ${ }^{46}$ and treat each public school as a private debtor in case of insolvency. ${ }^{47}$ A lighly specific himitation upon net assets is also imposed. ${ }^{48}$ These provisions are a guarantee, to the scliools, of a rough equality in competitive position and, to the students, of a fair use of public resources. If the state were permitted to pour additional money into a public school that was failing to attract students, the market stimulus to excellence would be diluted, and cliildren in the non-favored schools would be unfairly treated. The same

\author{
40. Id. art. 4, $\$ 3$. \\ 41. See part III infra. \\ 42. FCEA art. $7, \S 1$. \\ 43. Id. art. $7, \S 1$, art. $13, \S 9$. \\ 44. Id. art. $10, \S 1$. \\ 45. Id. art. $7,89$. \\ 46. Id. art. 14. \\ 47. Id. art. $12, \S 3$. \\ 48. Id. art. $12, \S 1$, art. $13, \S 4$.
}


would be true if private charitable sources sought to shore up a failing private school. Moreover, such a limitation is important to prevent affluent religious and ideological interests from using public funds as a base upon which to build the most prestigious schools. A refinement of this principle incorporated in the model would require an accounting for the fair market value of goods and services that are effectively donated, as in the case of teaching nuns. ${ }^{49}$ Together, these devices amount to a special Sherman Act for the education industry.

On the other hand, certain kinds of necessary or desirable school activities-pre-school programs for example-are not provided for within the model (though they could be if desired). Therefore, the cost of these activities could properly be borne by other sources, public or private. Provision is made in the statute for distinguishing and encouraging such special services, with cost reimbursement from state or private sources. ${ }^{50}$

Entry to the market for new private entrepreneurs is encouraged by a guaranteed loan program similar to the FHA structure. ${ }^{51}$ Again, however, access to credit is to be substantially equalized for all schools within the system-public and private-and detailed provisions are included to insure this result. ${ }^{52}$

The model is intended to apply initially only to urban areas selected for experimentation. ${ }^{53}$ This reflects both an estimate of the difficulties in supplying adequate transportation and a conviction that such a radical program must be tried first on a limited basis. However, where applicable it would be the exclusive public system except for specific provisions for handicapped and other special students and such experimental or compensatory programs as the legislature would permit or prefer to be operated separately. ${ }^{54}$

\section{Predicting the Consequences}

This sketch of the structure invites inquiry into the complex question of whether the model will accomplish the eleven objectives previously identified. ${ }^{55}$ Obviously a fair answer requires at least that serious reflection be devoted to the specific provisions and the explanatory comments of the FCEA. As to soine of the inore difficult questions, perhaps only a substantial legislative experiment with the entire model will
49. Id. art. $14, \S 3$.
50. Id. art. $7, \S 13$, art. $14, \S 2(1)$.
51. See generally id. art. 15 .
52. Id. arts. $12,15$.
53. Id. art. $3, \S \S 1,2$.
54. Id. art. $7, \S \S 10,13$.
55. See text accompanying notes $12-15$ supra. 
provide a valid answer. Nevertheless, it might be helpful to outline broadly and briefly the relation between means and ends that is expected.

\section{Neutralization of the Effects of Varying Wealth}

For constitutional, political, and practical purposes the rates of the family tax can be adjusted so as to balance reasonably the burden upon fainilies at all levels of incoine. Of course, any particular formula for creating equivalence of sacrifice can be challenged. Setting a proper relation among family imcome, tax rates, and levels of spending for education involves more judgment than mathematics. Errors in judgment are likely but not irreparable. If it appears that a given set of rates and spending levels tends in practice to separate children by income classes, adjustments can be made.

\section{Vesting Decisional Power in the Family Unit}

By definition the mechanism achieves its purpose of placing power and responsibility for clioice in the fanily. The issue here is the wisdom rather than the success of the policy. Depending upon his value preferences regarding human freedoin, parental rights, and sound educational policy, the critic may question how well parental choice would be exercised. In part, the answer depends upon the effectiveness of elaborate information requirements in the model ${ }^{56}$ and upon one's estimate of the judgment of parents compared to the judgment of educational administrators.

Of course, the question itself is unclear. If the issue is defined to be whether the "right" children will be sent to the "right" schools, the equally anibiguous response is that a fanily's choices for its children on the whole should be no less appropriate than those presently dictated by a statutory or administrative formula. What this statement of the question often implies is the criticism that the poor will "undervalue" education in the sense of choosing the cheaper schools more frequently than the rich. ${ }^{57}$ Obviously this is possible. The opposite is also possible. There is simply no experience upon which to draw, since the poor have never before been in a position of parity with the non-poor in manifesting their interest in education. About the only evidence we have is that poor districts today frequently tax themselves more heavily than rich districts. ${ }^{58}$ To the extent that personal poverty and district

56. FCEA art. $7, \S 1$.

57. See, e.g., EDUCATIONal Vouchers, supra note 3, at 38-40; see text accompanying notes 71-75 infra.

58. See Private Wealth and Public Education, supra note 5, at 75-197. There is also interesting data that suggests that blacks tend at least to verbalize a higher as- 
poverty coincide-a difficult correspondence to demonstrate on the basis of available statistics ${ }^{59}$ - one might conclude that the poor value education more than the rich and would thus tend to choose the most expensive categories. This, however, is as much a non-sequitur as the conventional wisdom that high spending districts value education more. In any view of the matter, the adoption of a family power equalizing model would represent a challenge to the leaders of the poor to assure that their clientele understood both the opportunity and the responsibility at stake. The options that the family would have to exercise do not seem so esoteric as to elude the understanding of ordinary men who are informed.

Of course a fundamental feature of the FCEA is that it permits families to place a value upon education which differs from the value that would be chosen for them by the bureaucracy. Unquestionably under the model some families would decide that their personal objectives are satisfied by spending less for education and, therefore, more for television sets, travel, or even (other?) vicious pursuits. Allowing this freedom is objectionable to some critics, a point of basic principle to which the authors will return.

\section{Efficiency}

It is easy to make too much of this point. For present purposes it is enough to say that the purchasing of educational goods and services plausibly could be accomplished with greater efficiency within a coinpetitive system than under current imstitutional arrangements. Beyond agreement on this fairly objective standard, there is little consensus over the basic goals of education. Hence, the question of efficiency is scarcely answerable.

\section{Accountability}

By permitting transfer froin school to school at any time, and providing the economic resources including transportation to support transfers, the model would allow all parents to exercise the fate control now reserved to those who can afford to use private schools. This power would be supported by a system of state regulation and of disclosure

piration for education than do whites of the same economic level. U.S. OFFICE of Education, Equality of Educational Opportunity 302 (1966); Sewell \& Shah, Parents' Education and Children's Educational Aspiration, 33 AM. Soc. REv. 191 (1968); Wilson, Educational Consequences of Segregation in a California Community, in 2 U.S. Commission on Civil Rights, Racial Isolation in the Public Schools 165 (1967).

59. Relevant statistics are ordinarily reported on the basis of governmental units such as counties which rarely coincide with the boundaries of school districts. 
and dissemination of information sufficient, it is hoped, to expose educational swindlers.

\section{Independence of Spending from Local Tax Referenda}

Here, again, the inodel is successful by definition. The cost of the systein would be borne in largest part by general taxes at the state level. The relative invisibility of sucl levies renders thein a vastly more dependable source than the higlly erratic local property tax from which the schools would be liberated. Statewide support also guarantees a ineasure of "equality" of education for the children of the state that may put at rest the objections of critics to a "district power equalizing" system with its geographical disparities in spending. ${ }^{.0}$ As previously observed, however, family choice invites the cognate objection that the child is unprotected froin his parents.

\section{Variety in Style and Content}

The stimulus to private action justifies a prediction of significant diversification. Unless the non-rich prove surprisingly homogeneous, schools out of self-interest will strive to accommodate the entire spectrum of their needs and interests. This would be true in both the public and private sectors. A inuch wider range of ideological and curricular responses seems likely among private groups. In particular, the now relatively uniform Catholic scloools would experience new pressures to satisfy the tastes of particular consumers. Since the economic control of formerly parisli schools would now pass to the parents, it is probable that a broad spectrum of choices would become available even within nominally "Catholic" education. It is not insignificant that most Catholic bisliops who thus far have engaged in the debate have favored purchase of services directly from private schools by the state-a distinctly "Establishment" approach giving state support to the proprietor rather than the parent and thus diminishing the probability of variety.

\section{Experimentation}

The threat to survival from coinpetitive pressures ought to stimulate increased experimentation even within the limits of the resources available to each school for its regular program. Provisions encouraging cooperative programs among the schools on a contract basis ${ }^{01}$ and the reimburseinent of the costs of special programs by the state would be strong additional incentives to experiment. ${ }^{\circ 2}$

60. See, e.g., Michelman, supra note 10 , at 53-59.

61. FCEA art. 10, 55 .

62. Id. art. $10, \S 4$ contains an exception to the egalitarian spending rcquire- 


\section{8. "Community Control"}

The current decentralization proposals appear to be hypocritical for at least two reasons: First, authentic community self-determination can only be a function of financial autonomy, and none of the proposals so far seriously advanced would yield power over the total budget to the local board. ${ }^{63}$ Secondly, any proposal based upon a geographically defined unit must tolerate frustration of minority viewpoints within the unit-the "community" is that group of residents which successfully imposes its programs on all the children of the district. ${ }^{64}$ Shifting to a family base would permit organization of non-geographical communities of interest which can be freely chosen and freely abandoned. Family power equalizing would permit such communities to operate with financial independence.

\section{Racial Integration}

The systen 1 proposed in the FCEA would probably increase racial integration in metropolitan areas in the medium and long run. Some differential burden would, however, be imposed upon minority group children im terms of travel time. In the initial operation of the system, the opportunity to attend any system school within a large area should cause at least some middle-class minority students to attend putatively superior schools in white areas. Thereafter, as performance scores on standard tests and other indices of success became better known through the mandatory publicity provisions, ${ }^{65}$ a larger emigration of students could be expected from schools with lower performance to those with better. Ultimately, the shifts and counter-shifts of this moveinent should manifest three effects: First, they would tend to depopulate schools in the ghettoes; second, they would tend to diversify social classes and races within the formerly white schools; and, third, such diversification would tend to lower and to level out the overall test performances of the niost elite of the formerly all-white schools. The nlagnitude of these moveinents would be modest, but eventually the result would probably be more stably integrative for densely populated areas than would be the results of any of the administrative proposals with which the authors have been associated or are familiar. ${ }^{86}$

ments; it permits each school to use $10 \%$ of its current income from the state for experimental purposes.

63. See generally CommuntTy CONTROL of Schools (H. Levin ed. 1969).

64. See Coons, Book Review, 23 Stan. L. Rev. 846 (1971).

65. FCEA art. $7, \S 1$.

66. Sample efforts are described in AffiRmative Integration (R. Hill \& M. Feeley eds. 1967). In general, involuntary inixing by administrative gerrymandering and busing has been effective primarily in accelerating white emigration from the central cities of the North. 
The effects of the FCEA in southern cities are more problematic. Much depends upon the realities of "freedoin of choice" in the southern context. At one extreine, it is possible that the model would be unconstitutional under Brown v. Board of Education ${ }^{67}$ in the formerly de jure segregated inilieu. ${ }^{68}$ At the other extreme it may be seen as a hope for integrating even the private sclool. There seems little doubt that private institutions subsisting on state funds will be required to ineet fourteenth amendment adinission standards. All this may render the model pohtically uncongenial to many southern states. If that is so, however, the model cannot be faulted as a threat to integration.

\section{Compensatory Education}

Whether the effect of the statute could fairly be called "compensatory" is largely a problein of definition. ${ }^{69}$ Providing access to excellent schools on the basis of equal family sacrifice seems a plausible approach to ameliorating the special burdens of the disadvantaged. It would be surprising if certain high spending schools did not specialize in a curriculum designed for disadvantaged children. Of course, such schools would have to be chosen by the parents, and some whose children need special attention would not choose these schools. It is impossible to determine whether such "bad" choices would nnake the entire system less coinpensatory than other inodels without accurately predicting both the numbers of such choices and the alternative systems of compensation foreclosed by the adoption of the FCEA. Moreover, there is nothing in the model which would foreclose other coinpensatory efforts outside the regular school programs and a provision could easily be included which would permit the infusion of limited compensatory resources within the model structure. ${ }^{70}$

\section{Political Feasibility}

Properly lobbied, the FCEA could produce nice combinations of bedfellows. It should be attractive to Black Panthers, John Birchers, Muslims, Cathohics (laymen, not the heirarchy), classical liberals, educational experimenters, property owners, residents of poor districts, and other disparate and overlapping cadres. It will threaten traditionalist school administrators, residents of socially tight and very rich suburban districts, philosophical centralizers, those who for various reasons would discourage social diversity, and the multitude who fear all change. It

67. 347 U.S. 483 (1954).

68. See Monroe v. Board of Comm'rs, 391 U.S. 450 (1968); Green v. County School Bd., 391 U.S. 430 (1968).

69. See Private Wealth and Public Education, supra note 5, at 245-54.

70. See FCEA art. 51, § 4, comment. 
would probably be opposed at first by conservative teachers' unions, although the opportunities for industry-wide bargaining and potential increase in the total pie might ultimately be persuasive. The total prospect seems problematic, but in an era of extreme frustration over educational failures and property tax absurdities, it would be a hardy prophet who would dismiss it as political nonsense.

\section{E. A Contrasting Model}

The Center for the Study of Public Policy (CSPP), in Cambridge, Massachusetts, working under a grant from the Office of Economic Opportunity (OEO), has proposed the rougl outlines of an experimental voucher system which provides a useful contrast to the family choice model..$^{71}$ The CSPP proposal is a modification of Dean Sizer's scheine for offering vouchers only to the poor. ${ }^{72}$ In geographical areas selected for experimentation, all children would receive a basic voucher worth a minimum of, say, $\$ 750$. Vouchers for the poor would be augmented in value in inverse proportion to the family wealth, up to a maximum voucher of perhaps $\$ 1,500$. Admissions to each school would be in part by lottery among apphicants with the balance of admissions (onehalf is suggested as a inaximum) to be picked by the scliool-at least in the case of private scliools.

The current form of the CSPP model would produce certain undesirable effects. The non-random admission program is the least of a nest of problems. The proposal would also permit private groups such as religious bodies to suppleinent the income that their schools receive froin vouchers, thereby bestowing an advantage upon wealthy sponsors over poor sponsors and of private scliools over public schools. This and many similar lacunae render the model unattractive in its present form, though it appears that the OEO intends to experiment with it. ${ }^{73}$ The proposal seems to be far froun its final form and will only be fully and fairly judged when viewed as a whole after the difficult work of drafting specific provisions is completed by the OEO or the CSPP. What can be said at this point in time is that, if properly articulated, the CSPP model would appear plausible and attractive to many critics of the existing system. It also poses a nice contrast in its fundamental philosophy to the family choice model.

A basic goal of the CSPP nodel seems to be to provide the variety and freedoin associated with voucher schemes while simultaneously equalizing the quality of schools within the system. This equality would be achieved by a trade-off of two basic inputs-money and good

71. Educational Vouchers, supra note 3.

72. See Sizer \& Whitten, supra note 14 .

73. Janssen, Education Vouchers, 6 AM. Educ., Dec. 1970, at 9, 11. 
students. The greater the number of low-achieving children in the school, the more dollars; the greater the number of high-achieving children, the fewer the dollars. "The price of choosing more advantaged classmates would be that the school had less adequate economic resources." While children would be free to shop around for differences in style, curriculum, or social mix, all would receive an education theoretically equal in quality. At least this would be so if we are willing to assume that the specific relations fixed between the ability of the students and the value of their vouchers are the right ones. Ironically, the CSPP calls its proposal the "Regulated Compensatory Model," an obvious misnomer. A more appropriate title would be the Uniform Quality Model.

The basic conflict between the two models is apparent. Above an adequate minimum spending level for education, the FCEA would permit families to implement their private judgments about the value of education compared to other purchasable goods and services. The CSPP model on the other hand would constrain poor families to accept a uniform political decision on that question. It would permit a wide choice of educational styles; the family could clioose between a public and a private school, a progressive or a traditional school, a Catholic school or a Lutheran school, a red school or a blue school. However, it could not choose between better schooling and better housing. The CSPP model would set an absolute value on education-or, more accurately, it would permit experts and legislators to set an absolute value on education. Their decision would fix the level of educational quality for all children whose parents could not afford private schools outside the system.

There are, of course, desirable aspects of the CSPP system. It has many of the virtues of equality while eluding many of the vices of uniformity. Children could have a kind of equality of opportunity while remaining free to be different. This seems unexceptionable and wortlyy of support as an experiment, or even more. Nonetheless, some caveats are in order. First, if equality is to be a decisive or at least significant value here, it is not clear that either the CSPP or the FCEA model is on this ground preferable to the other. Each model can claim its own kind of equality - the one an equality of input; the other an equality of power to control that input. It would be difficult to say which is the more "democratic." Yet thete is a significant difference, though not a simple one to describe. At first what seems to be at stake in the distinction between these two forms of equality is the radically different impact upon freedom of choice-the other value beside equal-

74. Educational Vouchers 55. 
ity which has tended to dominate voucher rhetoric. ${ }^{75}$ Clearly the CSPP model is much more restrictive in this regard. But this conclusion does not end the debate, for the freedom that is at stake here is primarily that of the parents; any freedom of the child is, at best, derivative. Indeed, if the child and the parent could be viewed analytically as independent of one another, the question might be posed pejoratively: Should we permit the FCEA to trade off the child's equality for the parents' freedoin?

Of course the inatter is not as simple as this, and few would suggest such a polarity in the child-parent relationship. However, the point is that there is a fair question concerning the degree to which it is appropriate to invoke the increase of parental freedom as a basis for preferring the FCEA model. In the end one's judgment on this issue will depend largely upon his view of the reasons for permitting families to have any choice in the first place. Is the preference of family over bureaucrat merely instrumental-- does the family simply make better choices? Or, does that preference spring from some deeper perception of the nature and proper prerogatives of the fundamental social unit? Or both? Or neither? More reflection will be necessary before the authors are prepared to make a coinmitment on what is a major philosophical issue.

However, it is fair to make one final observation of a more terres: trial order about the role of the family within the CSPP model. That system would tolerate-indeed encourage-the family to make decisions of the most sophisticated character. Parents could choose between and among a variety of curricular and pedagogical approaches. The authors concede to the CSPP proponents the capacity of parents to make judgments on these matters-judgments which on the whole would be as reasonable as those of the experts. But, if so, it is not clear why parents are unqualified to inake what are the much less sophisticated choices between and among spending levels. If parents can evaluate the nuances among academic programs, why would they be insensitive to the value of an extra $\$ 300$ in spending? Apparently the CSPP inodel assumes that the parent is competent to determine the kind of education but needs the help of the state to determine how much education.

Presumably, this anomaly in attitude is not explained by any concern that each child receive an adequate minimun education. If the minimum in the FCEA model were insufficient for that purpose, obviously it could be raised. Rather, there seems to be an unexplained disrelish for implementing the educational aspirations of poor parents wlo are willing to make an extra effort. The most one can conclude is

75. See, e.g., M. FRIEDMAN, CAPITALISM ANd FreEdóm. (1962). 
that the CSPP advocates do not wish to see children grouped according to parental attitudes toward education. Their report to the OEO describes such separation in the FCEA system as "cultural,"76 and, though the intendment is ambiguous, perhaps it is a reasonable description of the probable empirical result. Persons who, after any given level of educational quality is reached, prefer to consume other goods can fairly be said to share a "culture." What is not plain is the ground of objection to such parental choice. Morcover, it is not clear why a system which permits and encourages families to separate for education on the basis of religion and ideology balks at separation on the basis of culture. In the hight of the professed market orientation of the authors of the CSPP model, the enforced homogenization of quahty for the poor stands in need of a rationale.

\section{F. Pure and Mixed Power Equalizing Models}

The FCEA is a "pure" power equalizing model. All parts of the system to which the act applies are power equalized, and the system, with minor exceptions, preempts the field of publicly financed elementary and secondary education. For heuristic purposes, it was important to keep the model relatively pure. However, it is very important to see that a family power equalizing model could operate in endlessly different combinations with other voucher (or, for that matter, traditional) models.

For example, suppose that the CSPP model were adopted for the funding of schools, but that families were, in addition, permitted to purchase "school stamps" at prices which were progressively subsidized for the poor. If the school stamps were made redeemable for additional educational goods and services outside of school, a way would have been provided to assist the educational aspirations of those poor who are willing to make extra effort. Actually such a school stamp program could be superimposed on the FCEA model permitting the power equalized purchase by the poor of both schooling and outside educational services.

Obviously, all such combination schemes would need at least the same attention to statutory detail that has been given to the FCEA. The point is that a varied and flexible package of preschool, day care, schooling, and educational eontracting can be easily imagined, with all, or any part of it, power equalized.

\section{G. Preliminary Comment on the FCEA}

The provisions of the model statute have been drafted on two assumptions regarding the yearly school cycle. One is that the traditional

76. EdUCATION VOUCHERS 38. 
September to June school cycle will be maintained and the other is that the state would not wish to apply the system to accelerated education: Neither assumption is important to the operation of the system. Schools could be permitted to operate on any cycle they chose, and schools and their students could receive the benefits of the act for year round attendance. The latter would probably be more efficient and cost the state less in the long run. There do not appear to be any special difficulties in drafting such a flexible system; indeed, the result might be accomplished by a general directive to the Board of Education to adopt regulations adapting the provisions of the statute to a flexible and/or accelerated cycle.

Parts of the statute may require amendments to provisions of the California Constitution relating respectively to aid to sectarian and other nonpublic imstitutions, ${ }^{77}$ guaranteemg the obligations of non-public institutions, ${ }^{78}$ and the distribution of the School Fund. ${ }^{79}$ Those changes thought to be necessary would be incorporated in separate legislative proposals triggering the amendment process.

The model act is too complex and varied to sum up adequately in a brief and unified introduction. It has, therefore, been interspersed witl a multitude of comments, some more lengthy than the provisions explamed. The impact of the model upon the tax structure and the problems of the appropriate tax and spending rates for the model are explored in detail im part III.

77. CAL. Const. art. IX, $\S 8$, art. XIII, $\S \S 21,24$.

78. Id. art. XIII, § 25.

79. Id. art. IX, \& 6 . Other sections would become functionless and should be properly amended. For example, those sections relating to election of County Superintendents for each county [id. art. IX, § 3 ] should be altered to apply only to counties which include school districts. 
II

The Famiry Choice in Education Act

AN ACT to ADD Chapter ( ) RELATING to THE FINANCING AND ADMINISTRATION OF ELEMENTARY AND SECONDARY EDUCATION IN COUNTIES OVER 200,000 IN POPULATION TO Division ( ) of the Education CODE.

\section{Article 1 \\ DEFINTTIONS}

For purposes of this Act, the following definitions, unless context otherwise requires, shall be controlling:

(a) Superintendent shall mean the Superintendent of Public Instruction.

(b) Board shall mean the State Board of Education.

(c) Department shall mean the California State Department of Education.

(d) Chief administrator shall mean that employee of an individual public school who is principally responsible for the conduct of the affairs of such school.

(e) School age shall mean the age of compulsory attendance as defined in Division 9, Chapter 6, of the Education Code. ${ }^{80}$

(f) Custody shall mean the status of legal responsibility for and authority over a minor by an adult who may be a parent or either an adult or institution in loco parentis.

\section{ARticle 2 \\ REPEAL OF STATUTES}

All statutes, regulations and ordinances in conflict with this Act are hereby repealed or modified to conform to its provisions.

\section{Comment}

To supplement this boilerplate, the inany provisions in the California Education Code should be scanned for unintended conflicts and ambiguities.

80. Present compulsory school age in California is between 6 and 16 years. CAI. EDuc. CODE \$ 12154 (West 1969). 


\section{ARTICLE 3 \\ APPLICATION}

Section 1. This Act shall apply only within counties exceeding 200,000 in population, unless by referendum in individual counties a majority of those voting on the issue shall approve its application.

\section{Comment}

This general provision is drafted in what might be its ultimate legislative form. However, it is plainly necessary and desirable to commence on an experimental basis. This would mclude five to ten-year pilot programs in several urban areas large enough in population but sufficiently compact in size to constitute an efficient market. In addition, controls would be required to assure that the experiment yield intelligible data.

The basic structure generates soine problems of fairness between affected and nonaffected areas. We have taken as fundamental the proposition that variations in wealth should not affect the quality of publicly financed education. A family choice system for urban areas therefore should be accompanied by cognate reforms statewide to bring to an end California's historic discrimination among school districts. But if the proposed structure permitting four taxing and spending levels were adopted in urban areas, the problem of what would be the fair level of taxing and spending in the non-affected areas remains. Should all such areas be centrally funded at the statewide average expenditure? If so, how is the extra self-tax burden of article 16 of this Act on parents in the affected urban areas to be offset? One approach might be to eliminate all local taxes around the state but charge rural parents a tuition according to their incoine at rates parallel to those imposed through self-tax on those urban parents choosing the average spending level under the model statute.

Section 2. In cases where the area of any school district overlaps the boundary between a county subject to this Act and a contiguous county not affected by this Act, no part of the area of such district shall be subject to this Act unless by referendun as provided in section 1 of this article.

\section{Comment}

Alternatively, the system could be made optional for all counties. It should not be mandated for areas with low popula- 
tion density, at least until the efficiency of transportation in such areas can be assessed.

Section 3. The effective date of this act shall be January 15, 1972.

\section{Comment}

Dates have been specified throughout with no regard for political reality, but simply to make the relation of the dated provisions more concrete, hence more easily understood.

\section{ARTICle 4 \\ TRANSMISSION OF AUTHORITY FROM DISTRICTS \\ TO SUPERINTENDENT AND BOARD}

Section 1 . The authority over elementary and secondary education of elementary, high school, and unified school districts, the geographic areas of which are subject to this act, and the similar authority of counties shall cease as of 12:00 noon, July 1, 1973. Prior to that time the district board and county board and district and county officers having authority in such districts shall transfer the administration of the area to the Superintendent. As of the time specified, school districts affected by this act shall cease to exist and their property shall by virtue of this Act become that of the state in accord with article 8, section 2 of this Act.

\section{Comment}

The Superintendent's admimistrative apparatus need not correspond to previously existing districts. It seems likely, however, that the Superintendent would delegate some administrative authority to deputies with special responsibility for certain geographical areas whether former districts or otherwise.

Section 2. The State shall be responsible for the fiscal obligations of all school districts dissolved under this Act. Where such obligations include employee rights established under district programs providing retirement, disability, insurance, or similar benefits, the State shall assume responsibility for both the funding and administration of such programs. Existing programs estabhished by the State shall not be affected. Schools subject to this Act shall be empowered to contract with their employees for additional benefits which shall not be the obligation of the State but of the school only.

\section{Comment}

This would be a relative windfall to taxpayers in districts 
which have made heavy capital and other commitments. By and large these would be hard pressed districts of low wealth who have been the historic victims of the system. The cost of liquidating these old obligations would now be shared broadly through state taxes. New obligations (incurred now by schools, not districts) would also be supported indirectly by state taxes paid to schools in the form of tuition. However, school parents would pay an extra portion through the special income tax in article 16 . None of the support would coine from local residential property taxes.

Until July 1, 1973, the districts to be eliminated would still exist, and the provisions of this section could encourage reckless debt formation. Article 12, section 1, contains provisions to control this threat.

District-based benefits for employees would become state obligations only to the extent that they are "established rights." Such rights are relatively small in dollar amount and practically all retirement rights are presently a state responsibility except in a few districts among which, however, are some of the largest. ${ }^{81}$ It is important, however, that these rights be preserved against an entity of guaranteed solvency-not individual schools. Hence the state would adopt them, adding them to its existing retirement programs. It is worth noting that only a small part of these programs are currently funded.

Public schools which wished to supplement the state benefit responsibilities could do so. This would be a natter of negotiation with their einployees and the state would not be responsible.

Section 3. For the years 1972 and 1973 property taxes levied by school districts dissolved by this Act shall become due and payable as if this Act had not been passed. Thereafter, they shall cease. All collections for the year 1973 shall become available to the Superintendent for discharge of his responsibihities under this act. Collecting agencies shall transfer such funds to an account to be created by the Superintendent for that purpose.

Section 4. Until September 1, 1975, persons who are principals or assistant principals of public schools during the school year 1972-73 in areas subject to this act shall be preferred by the Superintendent in the selection and appointment of chief administrators for schools in categories $\mathrm{A}$ through $\mathrm{D}$ under this Act.

81. For example, San Francisco and Los Angeles. 


\section{Comment}

This section limits for several years the Superintendent's personnel preferences. The justifications for this are the humane and political ones supporting all job security systems that tolerate inefficiency. The protection for the principal is limited by the Superintendent's right to fire chief administrators under article 8 , section 2 , but is reinforced by the three-year salary protection of the same section. Further, as an ex-principal, a chief administrator who has been fired from one school presulnably retaims his right to preference in the selection of chief administrators for other schools. The firing itself would not be evidence sufficient to permit the Superintendent to permanently shelve him. Of course, the preference would yield where there was adequate evidence of the individual's lack of capacity.

Section 5. Except as altered by subsequent contract, the tenure and seniority rights of persons other than principals employed by school districts dissolved under this Act shall be recognized as follows:

(1) Prior to September 1, 1973, in hiring fulltime employees for schools in categories A through D under this act for service in school years coinmencing on or after that date, assignment preferences recognized under the previously existing district system shall be honored. After that date in hiring new personnel no preference need be given on the basis of an applicant's employment by any district dissolved under this Act. Any person not a chief administrator who is a full-time employee of any school in categories A through D under this Act on the first day of school in September, 1973, shall enjoy such rights of salary, tenure, and seniority agamst such school and within the staff or faculty thereof as he or she would have enjoyed had this act not been adopted.

(2) Any person who on July 1, 1973, enjoys within any school district tenure or other rights within a class of enployees by virtue of his qualification for or assignment to duties performed at two or more schools of such district shall be entitled to and contimued in employment of the same character by and for the Department for no less than the two school years following the effective date of this Act. So long as the Department recognizes a class of einployees substantially equivalent to the class of employees to which any such person belongs, except to the extent that persons of similar qualifications from other 
districts dissolved under this Act have greater seniority, he or she shall retain the rights within such class enjoyed at the effective date of this Act. If such person enjoyed salary. guarantees against a district they shall continue against the state so long as the right to employment endures. The services of such persons shall be offered by the Superintendent for purchase at cost by schools under this Act.

(3) All persons, other than those described in section 4 and in subsections (1) and (2) of this section, who are employed full-time by a school district on July 1, 1973, shall be given preference according to seniority in the selection of employees for such similar positions as are created by the Superintendent for the implementation of this statute. Wherever the nature of the employment by the Superintendent permits, rights similar to those held against a dissolved district shall be recognized.

(4) Wherever rights under this section were created under a collective bargaining agreement, that agreement shall bind the employer, whether a school or the Superintendent, insofar as the rights of an individual employee are concerned, and the contracting union shall retain the right to represent the employee for the period of the agreement.

\section{Comment}

Public school employees henceforward would be hired by individual schools, not by districts. Hence the need to provide for transition from the employment characteristics of present district systems. Some protection of pre-existing teachers' and other employees' rights is provided by transmuting them into rights against the school in a inanner and degree which vary with respect to the type of personnel.

Subsection 1 assures full-time district employees one last chance to exercise whatever assignment rights they would have had. Part-time employees would have no assignment rights. Once the new system is in operation, all employees would have whatever tenure, salary, and other rights they could negotiate against their school except that former full-time employees of the district enjoy precedence and protection within the school parallel to their rights against the dissolved district. Note that these rights are limited to salary, tenure, and seniority and do not include retirement, which is covered by section 2 .

Subsection 2 attenipts to provide reasonable protection for the more complicated needs and rights of such peripatetic em- 
ployees as nurses, psychologists, and similar specialists. This includes an absolute employment guarantee of two years plus longer range opportunities that, practically speaking, would seem relatively secure.

Subsection 3 is intended to cover employees of the district administration-the remaining general category of full-time employees to be protected. Part-time employees receive no special protection.

The rights of particular employees which rest upon union contracts would continue to be based upon those contracts during their duration but would now run against the school or Superintendent, whichever is the employer. This would be relevant, for example, in the processing of grievances against a school. It would be of strategic importance to unions in maintaining their hold on members and in gaining entry to schools and to the various segments of the Superintendent's now substantial body of personnel. Requirements that the statute imposes on applicants for teaching positions in public and private schools are dealt with in article 10.

\section{ARTICLE 5 \\ PRIVATE SCHOOLS NOT AFFECTED UNLESS BY CHOICE}

No private elementary or secondary school shall be affected by the provisions of this act unless it is certified or currently seeking certification as a school within categories $\mathrm{E}$ through $\mathrm{H}$ under article 13 of this Act.

\section{Comment}

The question would arise whether schools not in the system slould receive any aid in any form. The authors would prefer an explicit statutory prohibition. Such aid would generally be inconsistent with the purposes of this Act. Perhaps an exception should allow for the purchase of specialized services not elsewhere available.

\section{Article 6 \\ DUTY OF PARENTS AND OTHERS HAVING CARE AND CUSTODY OF A CHILD}

Any person, persons, or institution having custody of a child of school age shall enroll such child in a school to be selected by such person or institution, which school shall either be certified under this act or be a school otherwise satisfying the ininimum standards fixed by law. Where the custody of such a child is in other than a natural or adoptive parent, the person or institution having such responsibility shall enroll 
the child in a school appropriate for the child giving consideration to his natural abilities, development, interests, and personal choice. Persons or institutions with custody of a child below school age but eligible for kindergarten may in their discretion enroll him or her in kindergarten.

\section{Comment}

Each child will have someone responsible for choosing his school. In most instances this will be the parents. However, if the parent gives up or is legally deprived of custody, it would be preferable for the institution or person given custody to choose the school. In such cases, the parent will rarely be both coinpetent and concerned for the child's welfare. To the extent that the child is competent and mature, the guardian can give weight to his opinion. In cases where the parent's objective is merely to limit his tax hability under article 16 , the guardian may protect the child's welfare by a disinterested choice. It should be understood that the parent pays the tax, not the guardian. ${ }^{82}$ No doubt this would tend to put such children in the more expensive schools. This indirect preference does not seem invidious in the light of the disadvantages that generally burden the lives of these children. Moreover, their numbers are relatively few.

Note that children for whose education no person is responsible as taxpayer under article 16 inay enroll "free" in any school under this Act chosen for him by the person or institution having custody. The school of course would be credited with an additional student.

The probable social effects of the parental duty to choose are complex and not altogether predictable. One interesting question concerns the psychological effects of the power to choose. Would this important, shared responsibility work to cement and mature marriage and familial bonds or undermine thein? Would ghetto family life benefit from a new sense of power and responsibility? Will too many parents feel driven by pride to choose the most expensive school? Will others choosing less expensive schools fear later reproof and reprisal by their children? Would such fear be realistic? If parents will be driven by such considerations to choose better education, is such a result to be deplored? Will it produce statewide overinvestment in education? Can this be controlled properly by increasing the parents' share of the cost (by adjusting the tax rates in article 16)? Should the statute provide a mechanism for selection where two parents reach irreconcilable disagreement on schools?

82. FCEA art. 16, $\S 2$ provides for limited liability of the parents in such cases. 
Should the child himself be given some choice? For example, should high school students be empowered to choose their own schools? This important issue is made more difficult under a power equalizing system than other more constricted models because under the FCEA the parents pay the tax. Is it fair or wise to saddle them with the liability for an expensive school chosen by the child against their wishes? Isn't it enough that the child enjoys the opportunity to influence that choice at close range every day? There may be a middle ground on this question which consists of giving the child power to veto a limited number of parental choices without giving him the right of specific selection. A state that felt more daring might give the child the option to select a school and to pay the tax himself through hypothecation of future earnings. Milton Friedman has outlined the characteristics of such a system for financing vocational education. ${ }^{83}$ It could be adapted to a general system of the kind proposed. Needless to say, there are significant legal and practical problems that would have to be faced. ${ }^{84}$

Note, finally, that the duty to enroll children "of school age" does not forbid the enrolling of children above school age. In fact, most high school juniors and seniors are today above the compulsory age. Of course the tax for their attendance would be payable irrespective of their age (until the age of emancipation). Under the FCEA the parent thus would have some incentive to withdraw his children from school after age 16 . If this were thought to be bad policy, either the age of compulsory schooling could be raised, the child himself could be given the choice to continue, or other accommodation could be made.

\section{Article 7 \\ RESPONSIBILITIES OF THE SUPERINTENDENT WITH RESPECT TO SCHOOLS IN CATEGORIES A THROUGH H}

Section 1. The Superintendent shall establish procedures under which those responsible for selecting schools under article 6 shall by a specific date no later than January 15 indicate their first and at least two alternative choices of specific schools for each child for the next school year. On that same date, taxpayers, if any, responsible for each such child under article 16 shall, under procedures to be prescribed by the Superintendent, estimate their anticipated adjusted gross income for the

83. M. FriedMan, supra note 75 , at $100-07$.

84. Among them are the possible institutional difficulties (including the thirteenth amendment) of binding mmors to long term obligations and the practical problems of tracing debtors and enforcmg their liability.: 
applicable year. At least 60 days in advance of that date those responsible for selecting schools under article 6 shall be supplied a coinplete list of names and addresses of schools in categories A through $\mathrm{H}$ located within an area at least as large as that for which transportation is to be available to the particular child under section 9 of this article. The list shall plainly note at least such special characteristics of each school as may be reduced to a convenient code. At the minimum these shall include: (1) per pupil cost category (A through $\mathrm{H}$ ); (2) the tax consequences of choosing each school for each income group under article 16; (3) religious affiliation, if any; (4) curriculum specialties, if any; (5) maximum enrollment fixed by the school under article 10 , section $2 ;(6)$ average score on the tests required under section 12 of this article; (7) faculty-pupil ratio; (8) actual current expenditure per pupil during the previous year; (9) number of applications the previous year; (10) whether the school's curriculum is fixed by the Superintendent or faculty under article 8, section 5 .

With the exception of children determined under section 10 of this article to be incapable of benefitting from education in schools under this Act all children shall be eligible for enrollment in any scliool under this Act. Where individual selections of a particular school exceed the inaximum enrollment fixed by that school, admission to that school shall be determined by lot except that students in attendance at such school the previous year (but only after September 1973), their siblings, and the children of the founders of such school where such school is in categories $\mathrm{E}$ through $\mathrm{H}$ shall have preference.

The selection of schools and assignments thereto in accord with article 10, section 3 , shall be completed no later than the February 15th preceding any school year. Prior to April 1st, the Superimtendent shall report to the Legislature the expected enrollment in various classes of schools in the coming school year and the anticipated total subvention necessary under this Act.

Choice of a school inay be altered (or, in the case of new residents, inay be first made) after the original assignment process is completed, provided that the new scliool chosen has space under the standards set by article 10, sections 2 and 3. During the school year a child may transfer from one school to another including schools in different categories, subject to the alteration of tax liability arising from certain transfers as provided in article 16 , section 2 . However, no school is required or permitted to accept a transfer or late registration which causes its enrollment to exceed $105 \%$ of its estimate. The Superintendent may make exceptions to such enrollment limitation in case of objective personal hardship, but in such event shall take steps to assure. that adequate space will be available the succeeding school year. 


\section{Comment}

This section is intended to serve several ends. First, it optimizes the possibility of an intelligent selection by the parent and permits responsive planning by the state to meet the cost of the parents' selections. The state's total cost cannot be finally estimated until the choices of specific parents are known.

The information provisions of the first paragraph probably can be implemented in such a way that parents can make the intelligent choices on which the entire system depends. In the Superintendent's booklet mailed to all parents, the schools first could be divided into the four spending and related tax groups, for the primary question most often will be how much the family wants to spend. Having made that choice, the family's evaluation of the subtler information in the package should be manageable. One might predict that, even in the densely populated areas, no more than 250 schools would be likely to operate in any one spending category within the range of the transportation provided under section 9 of this article. Careful consideration of alternatives would be necessary, but such an autonomous exercise of judgment could be a healthy experience, especially for families inured to dependency.

Inclusion of the prior year's racial data for each school was considered and rejected because of its ambiguous intendment. It could be taken as an invitation to indulge racist preferences. Its absence seems unlikely to make the Act less effective in desegregating schools.

The provision assuring every child equal access to every school is not entirely consistent with the market concept of education underlying the system. The school is treated to this extent as a public utility available to all. In practice, however, the characteristics of the school's program probably would have a tendency to attract in larger proportion those children the school would have admitted had it been allowed to choose among applicants. Indeed, there is nothing to prevent the school's counseling against a student's choice or advertising that the school is designed to serve best a student having certain characteristics. What is gamed by the guarantee is, first, the freedom of the student to reach higher than the predictions of experts based upon standard criteria, and, second, a defense agamst some of the subtler forms of racial, economic, religious, and social segregation. To the extent that such segregation remained, it would, at least, bear some relation to personal aspirations and interests freely exprcssed and implemented. 
It is inevitable that some parental choices would be frustrated by oversubscription of particular schools and consequent relegation of children to schools considered an inferior bargain. It is difficult to predict the significance of this "disappointment" factor. The creation of new expectations can, of course, be risky, but the degree of resentment at their frustration should be tempered by an apprehension of the fairness of the system. Today even the constant and demeaning diversion of specific applicants from the more prestigious campuses of the University of California creates only the mildest reaction. Under the statute such rejections would be random and thus, there would clearly be no rational basis for serious resentment. In reality, however, parental attitudes would depend upon the success achieved in creating understanding of the system. Of course, the assumption throughout is that adequate space would be available. In some areas, this could depend upon the rapid growth of new public and private schools. Only an experiment could test the interest of private suppliers. Article 10, section 2 is designed to insure sufficient overall space.

A separate section would be needed for the transitional year. Parents, schools, and the state should be given sufficient lead time before the switchover to cover the full cycle of preparatory decisions. These include the selection of spending categories for both public and private schools followed, first, by the preparation and distribution of information to parents and, second, by their selection of schools by January 15 th and their assignment by the Superintendent by February 15th, 1973. If the statute were passed on the date this Article was published the dates used would be realistic. That is, roughly a two year lead time should be anticipated. The transition section has been eliminated in the model for the sake of brevity.

Section 2. Upon notification to the Superintendent by a school under this Act of the enrollment in that school of any child on the second Monday of any school year, such child shall qualify for a tuition credit in the amount of the tuition (plus cost adjustment, if any, under section 4 of this article) fixed for such a child by article 11, section 1 or article 13, section 1 of this Act. Such amount shall be credited on behalf of the child to a tuition account to be maintained for the children of each school by the Superintendent. Children who enroll in a school under this act after the second Monday of any school year shall be entitled to that pro-rated share of the tuition fixed by this Act for attendance at such school which is allocable to the remaining portion 
of the school year; that amount shall be credited to the tuition account for the children of such school. Before the tuition account of any school can be credited with the amount allocable to any child, the person or institution responsible for such child under article 6 shall attest in writing to the bona fide enrollment and attendance of the child in such school. When a child withdraws from a school under this Act after the second Monday of any school year, the pro-rated share of the tuition credit allocable to the remaining balance of the school year shall be debited to the account for the children of that school to which it had previously been credited. Schools shall promptly notify the Superintendent of every withdrawal, formal or de facto, and the date thereof which shall be the last date of actual attendance.

\section{Comment}

The awkwardness of describing the tuition account in terms of the children rather than simply the school is perhaps obvious. Its function is to divert the constitutional objections that arise when the private religious school rather than the child himself is viewed as the primary object of the state's benefice. The device is, however, a perfectly honest one, since the object of this structure is im fact to benefit the child, not the school. The administration of withdrawals by the schools from their tuition accounts is governed by articles 11,13 , and 14 .

Inefficiencies are caused by transfers during the year, especially for the sending school. These might be compensated for in extra allowable costs, perhaps under the broad language of section 4 as now drafted. Schools that today charge tuition-both public and private-enforce forfeiture of that tuition after specific deadlines. This is intended, in part, to offset losses caused by transfers. Soine of these losses are "deserved" in the sense of being the effect of the school's own failure to satisfy its customers. Some of the losses are the result of factors not the "fault" of the school. Detailed statutory resolution of the problem seemed too cumbersome to be justified by its relatively modest significance.

Section 3. In order to assure that the purposes of this Act are achieved, the Superintendent shall recommend to each session of the Legislature appropriate changes in the levels of tax rates under this Act and their relation to income and to the amount of credit to be allowed the tuition account of the children attending each category of school. Such recommendation shall be accompanied by a prediction of the effect of such changes upon the cost of the program to various classes of taxpayers under this Act and to the citizens of California in general. 
Section 4. In determining the credit to be entered in the tuition account for the children in any school under this Act the Superintendent may add to the amount fixed by article 11 , section 1 or article 13 , section 1 , an amount not to exceed ten percent reflecting differences, if any, in the cost of purchasing educational goods and services within and among the areas affected by this Act.

\section{Comment}

The concept "cost of purchasing educational goods and services" is sufficiently broad to permit the adjustment of two kinds of differences in cost. The first is the general difference in cost of living from one area to another; so long as the statute applies only to urban areas such differences within most states are not likely to be dramatic. The second kind of difference is that in the cost of attracting qualified personnel to various parts of any inetropolitan area. The section represents an attempt to provide economic equalizers for scliools in nnattractive areas. Under the $10 \%$ margin, the total increase in cost to the state probably would not exceed 3 to $4 \% .^{85}$ This specific margin is, of course, quite arbitrary both as to its magnitude and its uses. Some might prefer an elaborate set of preferences for disadvantaged children, vocational education, and other particular programs. Such preferences could be as tightly defined or as discretionary with the Superintendent as the legislature wished. The point is that there is flexibility to promote whatever policies the state desires, so long as it does not thereby frustrate the general purposes of using the family as the basic unit of decision.

Section 5. The Superintendent shall establish uniform systems of accounting to be employed by all schools under this Act. Accounts shall disclose the sources and ainounts of all income whether in money, personal or real property, or donated services, and such records shall be public. Capital and current expenditures shall be clearly distinguishable.

\section{Comment}

The income disclosure provision is one part of the subsystem for insuring that schools must subsist essentially on their ability to attract students with a program costing no more than the statutory amount for schools of their class. The reasons for this are two-fold: First, it is a stimulus to efficiency; second, it is a guarantee that state funds will not indirectly be turned into

85. It could only approach $10 \%$ if one area were at least $10 \%$ below the cost levels of all the others. This risk would be eliminated by using the average cost as the base. 
a foundation upon which, through "voluntary" contributions, wealthy families or institutions may sustain the privileged position now enjoyed by wealthy school districts. This system of checks is developed in article 14 .

Section 6. Out of general revenue, the Superintendent shall provide for sucli common facilities for the use of students enrolled in scliools under this Act as lie deems necessary and proper. He shall extend the use of such facihties to the students of all schools under this Act in a fair and equal inanner. Each user school shall pay a fee based upon that portion of the annual current cost of each facility allocable to the use inade of that facility by sucli school.

\section{Comment}

This device (and the cognate section 7) for realizing econonries of scale through government is possibly unnecessary in view of the cooperative ventures permitted under article 10 , section 5.

Section 7. The Superintendent shall maintain a system of central purchasing designed to inaximize the advantages of large scale buying for the schools under this Act, all of which may employ its services in exchange for a share of the total cost of the system calculated according to the school's pro-rated share of the dollar value of all purchases made through the systein.

Section 8. The Superintendent shall establish and administer a fund for insurance of any schools under this act against damage from vandalism. Terins and rates for such insurance shall equal the current commercial terms and rates $\mathrm{m}$ areas of average incidence of vandahism.

Section 9. From general revenues and sucli other sources as the Legislature may direct, the Superintendent shall assure the availability of transportation, guaranteeing efficient and convenient aceess to a variety of schools under this Act for every child residing in areas affected by this Act. The support of transportation shall be confined to distances which are reasonable giving consideration to density, variety, demand, and to common practice im areas not subject to this Act, but in no case shall the allowable distance be fixed at less than four miles for any child. Support may take the form of reimbursement of costs to individual schools or families for that portion of transportation falling within permitted distances. 


\section{Comment}

The four-mile provision represents a judgment of the minimum distance necessary to ensure that urban black children will have access to the same variety of schools available to children in white residential areas.

The section would permit the organization of an integrated and comprehensive public system of transport. More sensibly it would permit individual schools and groups of schools to arrange for transportation of their own students.

Section 10. The Superintendent shall maintain from general revenues and such other sources as the Legislature may direct a system of free education for every child of school age who (after opportunity for hearing and review as provided in article 19 and article 20, section 2) is found to be physically, inentally, or emotionally incapable of benefitting from education except in a special school for children with similar difficulties. For the services necessary to such a system the Superintendent may: (1) establish separate institutions; (2) contract with schools in categories $\mathrm{E}$ through $\mathrm{H}$; (3) direct their performance by schools in categories $A$ through $\mathrm{D}$, in which latter case the full cost of such services shall be borne by state sources other than the tuition account of the children attending the regular program of the school affected.

\section{Comment}

It would be possible to treat institutions for children with special learning probleins as any other schools under the Act. There is no reason to suppose that no schools specializing in liandling blind or emotionally disturbed children would arise within the A through $\mathrm{H}$ categories. However, schools for such children would tend to require greater economic support, and, at the very least, a separate spending schedule for thein should be considered. ${ }^{86}$ There is also, however, a political difficulty in applying the statute without alteration to such unfortunate students. Individualistic values which would permit and approve differing family choices in the case of normal children tend to be replaced by an egalitarian paternalism when the child is defective. Indeed, opponents of the overall proposal no doubt would capitalize on this sentiment by likening the culturally disadvantaged child to the defective child. The objection, lowever, is misplaced. So long as the disadvantaged child has the

86. The authors have not provided a separate spending schedule. 
capacity to function in a curriculum designed for normal children, it is plausible that the compensatory education he needs will be provided best by a family choice system.

Section 11. The Superintendent shall report to the Franchise Tax Board the class of school attended by each child of each person responsible for the tax on income levied under article 16 herein.

Section 12. Each school year the Superintendent shall conduct a testing program for all children in schools under this Act. Testing shall be independent of any participation or administration by the personnel of the schools. The content of the tests to be admimistered shall be kept confidential so as to imsure that no school may prepare its students specifically for such tests. Such tests shall be conducted in October and May. Thereafter, the character of such tests and the results by grade and/or by age group within each school under this act shall be public record.

Section 13. Where the Legislature has specifically authorized the obligation of funds for such purposes the Superintendent may contract for the performance by schools under this Act of experimental or compensatory programs. Such contracts shall be performed by the school at cost and sliall be awarded without preference for any particular classification of school under this Act.

\section{Comment}

There is a risk that particular programs for which the legislature provides special funds outside and beyond the tuition account might upset the equality of opportunity for all schools at which the statute aims. Uneven dispensation of state funds for special programs might occur in a number of different ways, not excluding the design of a Superintendent to prefer particular schools. The protections in this section against such a result are relatively weak. However, the quantum of appropriated funds devoted to such special programs when compared to the total budget for the system would be too small to justify elaborate and cumbersome statutory controls of administrative behavior beyond the protections of the California Administrative Code. Moreover, any substantial departure from neutrality by the Superintendent would be a highly visible invitation to political retribution, 
Section 14. The Superintendent shall administer whatever federal funds are made available to his office. However, where funds are earmarked by a federal authority for a particular school or schools under this Act, the Superintendent shall not be empowered to direct the exercise of the discretion allowed that school or those schools under the federal grant.

\section{Comment}

The insouciance and success with which federal objectives have been disregarded in the past indicate the need for their special protection through this and perhaps other mechanisms.

Section 15. The Superintendent shall have the authority to select a number of promising children not to exceed 6000 from schools in categories $A$ and $E$ and 4000 froin schools in categories $B$ and $F$ who shall then be entitled to attend a school of their choice without additional tax cost to their parents.

\section{Comment}

This section derives froin a suggestion by Charles Benson that there be some chance for rewarding and fostering good performance in the less expensive schools. The advantages are obvious. It has the defect, however, of diluting the excellence of the sending school. It also might be difficult to administer, since the sending school would tend to camouflage their "promising" students for fear of losing them. Perhaps those schools could be compensated by continuing the transfering child's tuition there as well as in the receiving school. In any event the numbers involved would be likely to be relatively sinall both for any one school and in total.

\section{ARTICLE 8 \\ POWERS AND RESPONSIBILITIES OF THE SUPERINTENDENT WITH RESPECT TO SCHOOLS IN CATEGORIES A THROUGH D.}

Section 1. Insofar as resources are available and it is economically and educationally sound, the Superintendent shall establish schools sufficient to meet all deinand for schools in categories A through D.

\section{Comment}

A prior draft of this section contained a provision guaranteeing that an adequate publicly owned and operated school should be available to every child. This is probably a sound principle, but, on balance, it is a provision that the authors would add when and if the need arises. Public schools would not be ex- 
pected to fail in large numbers, leaving potential customers with only private schools available in their area.

A guarantee that an adequate public school will be available is conceptually inconsistent with the market principle. It would require a readiness to subsidize an unpopular public school beyond the amount in the tuition account, thus violating the equality of status among the schools. Nevertheless the authors would approve it.

Section 2. On or before noon on July 1, 1973, the Superintendent shall accept from former district and county authorities in areas subject to this Act the administration of the public schools below the junior college level and shall thereafter conduct their affairs in accordance with the provisions of this Act. All real and personal property owned by such districts shall thereupon become vested in the State and shall be subject to the authority of the Superintendent, under regulations adopted by the Board, to maintaim, control, and convey until and unless such property is allocated and conveyed to a school within categories A through $D$ under this Act. The proceeds of any sales of such property shall be available for the purposes of this Act. The Superintendent shall promptly identify and classify all public schools according to the categories $A, B, C$ or D under article 11, section 1 . He shall assign to each school real and personal assets, including those formerly owned by districts, which are adequate to its proposed curriculum and its estimated student population, and such assets shall thereupon become the separate property of such school and be subject only to the debts of such school in accord with article 12, section 3, of this act and shall not be subject to recall by the Superintendent unless the school is abolished as a school under this Act under section 3 of this article. For each school le shall appoint a chief administrator who shall be a full-time employee of that school and shall be compensated entirely from its separate resources. The chief administrator shall be subject to removal at all times by the Superintendent. In the event of such removal he shall continue to receive his salary undiminished until two years from the beginning of the next school year. The Superintendent shall establish a system for separate accounting by each school and, by regulations of general effect adopted by the Board, may affect the exercise of the authority of the chief administrators in a manner not inconsistent with the provisions or purposes of this Act.

\section{Comment}

The object of the first two sentences of this provision is to place the state authority in full ownership and control of the 
facilities previously administered by districts. It is not unlikely that much of the administrative machinery of the larger districts would remain functional and that many personnel would continue in positions similar to those held under the district administration. The succeeding sentences give the Superintendent the responsibility of designating the entities which shall be the public schools under the new system and of deciding, within limits, what assets each school shall have. Once this is done and the assets assigned, the scliool becomes a semi-independent creature, in many respects reseinbling a non-profit corporation whose capital has come from the state. The school owns whatever assets are originally assigned to it or are thereafter purcliased by it. These assets are subject to the rights of creditors, and can return to the state only upon dissolution of the school leaving a net balance of assets over obligations. ${ }^{87}$ They cannot be transferred from school to school without adequate consideration.

Note that the Superintendent need not assign all present school facilities to the $A$ through $D$ schools but may consign thein to other educational uses or sell them, if the cash proceeds would be more useful than the facilities for purposes of this Act. He may decide, for example, to build from the proceeds new facilities for A through D scliools which he will thereafter designate. $\mathrm{He}$ has a continuing duty and authority within available resources to plan and build new schools which anticipate or respond to parental demand.

The Superintendent also is to fix originally the per-pupil spending category of each school. Thereafter the power to alter categories would be divided. The chief administrator could do so under section 4, but only with the approval of the Superintendent. The Superintendent could do so but only by regulation of general effect. This power would be important in responding to shifting demand patterns. It also raises problems. Parents who have chosen a school would liave justified expectations about spending. At a minimum these interests should be given consideration, perhaps by phasing the new level in grade-by-grade. A statutory standard is possible, but too narrow a restriction should be avoided.

Under section 5 of this article, the Superintendent also has certain power to establish schools with curriculum specializations such as art, music, science, or vocational training. He could also create clusters of schools or.educational parks.

87. See FCEA art. 12, § 3. 
There is a potential departure from consistency in the outright transfer of ownership from the district to the state and, thence, to the school. Unless the Superintendent assured otherwise, it could produce mutually competing public units which would vary widely in the excellence of their plant. This possible inequity among public schools is moderated by the provisions of article 12, section 1, giving the Superintendent an extended period during which to modernize the worst public plants out of general state funds. Of course, this provision only increases the competitive advantage held by the public schools as a class over most existing and all new private schools. This advantage could be eliminated if public schools were required to "buy" their own plant out of tuition incoine over a period of years. The advantage, of course, would then shift to existing private schools thereby requiring further balancing devices to achieve true economic equality of opportunity. The authors do not oppose such a "perfect" system and consider it plausible. However, the advantage to public schools is tolerated for two reasons. First, this is a simpler solution and, second, it may be wise to give the bureaucracy this relatively short-lived period of advantage in which to develop the competitive muscle needed to survive.

Section 3. The Superintendent through regulation shall assure that schools in categories A through D under this act are operated with efficiency within the limits of the credit in the tuition account for the children of each school plus such additional income and credit as are permitted specifically by this Act. The Superintendent shall have authority to dissolve any such school which is:

(1) unable to meet current obligations or in immediate danger of becoming unable to do so; and

(2) ineligible for credit under article 12 and unable to obtain credit in the market on ordinary terms; and

(3) unable to obtain an agreement with creditors sufficient to guarantee its continuation as an adequate and independent school.

In no other case shall the Superintendent have authority to dissolve a school unless his decision to do so is confirmed by a majority of those full-time faculty of such school voting by secret ballot after ten days written notice of the referendum to each such faculty member.

\section{Comment}

If the Superintendent had unencumbered authority to dissolve schools, he could employ it to police faculty attitudes and 
performance in an inappropriate manner. Schools which offended his personal taste or judgment could be dissolved and promptly reformed in accord with his image (at least if the net assets of the school were adequate to start another). However, some mechanism is needed to permit termination of schools unable to avoid the insolvency provisions of article 12 , section 3 , or to make a satisfactory arrangement with creditors.

Section 4. The chief admimistrator of each school in categories A through $\mathrm{D}$ shall be primarily responsible for planning and conducting the affairs of the school. He shall have authority to hire and discharge personnel and to negotiate wages and other benefits and conditions of employment for his school's employees, unless the Superintendent, with approval of the Board, shall establish for such schools, either unilaterally or through collective bargaining, standards for wages, benefits, and conditions of employment of more general application. The chief administrator shall have authority to purchase equipment and supplies, to make capital additions and improvements, to pledge the credit of the school, and to alter the maximum enrollment, except to the extent that the Superintendent, with approval of the Board shall establish rules of general effect regulating the exercise of each of these powers. The chief administrator, with the consent of the Superintendent, may alter the perstudent spending category (A through $\mathrm{D}$ ) of his school. Except for the preferences accorded former primcipals under article 4, section 4, the Superintendent shall have the power to choose chief administrators solely upon the basis of personal qualification to carry out the purposes of this Act.

\section{Comment}

The role of the chief administrator is obviously as new as the rest of the statute. He is principal but, in a limited sense, is also entrepreneur on behalf of his school. He is given power to adjust the character of his school to the customers' wants, yet is constrained in many ways in the interest of stability and pohtical acceptance. The Superimtendent, for example, may fire him (under section 2), and may mdirectly reduce his discretion by regulation.

However, even with a pliant Board, the regulatory power of the Superintendent could prove to be more apparent than real. Such control would have to be exerted generally over a class of schools and could not be the basis of a detailed control of a particular school. To the extent that regulations constricted the options of all chief administrators the Superimtendent would risk giving advantages to his private competition. 
The power to remove the chief administrator is itself subject to severe practical limits not the least of which is the continumg cost of his salary under section 2 . In addition, if the administrator is popular, his removal would threaten the viability of the school. The overall effect is intended to be a reasonable balance in which incompetents can gradually be replaced, men of ordinary abilities can expect fair treatment, and parents can protect good administrators from arbitrary action of the Superintendent.

Section 5. At the same time the Superintendent classifies a school's spending level under section 2 he shall classify the school as to the manner in which its curriculum shall be determimed. Each school shall be designated either a "Superintendent School" or a "Faculty School." As to the former the Superintendent may, with the approval of the Board, issue regulations fixing the subject matter to be covered in such detail as he deems necessary, desirable, and rcsponsive to parental demand. So long as the minimum requirements of article 10 , section 12 , are met he may designate among such Superintendent Schools such specialized schools as he deeins necessary, proper, and responsive to parental deinand. Such speciahties may include art, music, science, business, secretarial skills, and the trades and vocations. Superintendent Schools may be created to serve no inore than three-quarters of those pupils expected to attend schools in categories $A$ through $\mathrm{D}$ within any area. Schools in categories A through D not designated Superintendent Schools shall be designated Faculty Schools. In such schools the full-time teaching faculty and the chief administrator, within the requirements of article 10 , section 12 , shall fix the curriculuin and emphasize such studies as they deein necessary, proper, and responsive to parental demand.

\section{Comment}

Large scale curriculum decisions could be handled in ways that differ greatly from this section. These provisions were drawn to give the Superintendent the option to centralize or decentralize curriculum choices for three-fourths of the public school population. He may hoinogenize these schools (with the Board's approval) but he thereby runs the risk of losing pupils to more flexible and varied schools. Among these would be not only private but also those puplic schools whose curriculum is fixed by the faculty. Thus, the existence of Faculty Schools would provide for another plane of competition among the public schools. 
Article 9

POWERS AND RESPONSIBILITIES OF THE SUPERINTENDENT WITH RESPECT TO SCHOOLS IN CATEGORIES E THROUGH H

Section 1. Upon the filing of an application with the Superintendent by an individual, corporation, or association of any kind for certification of a school within categories $\mathrm{E}$ through $\mathrm{H}$ under this act accompanied by the declarations and information affidavits required by article 13 , section 2, the Superintendent promptly shall make whatever additional inquiry and investigation he deems appropriate to determine: (1) whether the applicant will satisfy the minimum health and safety standards fixed under section 8 of this article; (2) whether the proposed curriculum will meet the minimum standard fixed by article 10 , section 12; (3) whether the faculty of the sclool will meet the minimum standard fixed by article 10 , section 11 ; (4) whether the information supplied under article 13, section 2, is accurate. Unless the Superintendent determines within four nonths after receipt of an application that the operation of the proposed school would be in violation of the above standards or that false information has been supplied, the certificate shall be granted. The Superintendent may inake such certification provisional in accord with the provisions of article 13, section 2.

\section{Comment}

In the transition period it may be desirable to extend the four months permitted the Superintendent to handle applications.

The Act permits literally anyone to own and operate a private school under the Act. Curiously, as Professor Michelman has poimted out privately, this could include governmental entities such as municipalities which could found schools in categories $\mathrm{E}$ through $\mathrm{H}$ if this were not ultra vires under their enabling statutes. In soine respects such schools may be desirable. They would permit a form of local political action, preserving much of what is good in school district politics. They would assure a "public" option in addition to the schools set up by the state. Perhaps this would produce schools with a different style, adding to the general variety. Since these schools would be subject to the general limitations upon income and net assets, the varying wealth of the cities would have little pernicious effect.

Section 2. Substantial violation of this Act or any other valid law or regulation in the formation or operation of any school shall be ground for decertification. However, non-continuing acts of an individual em- 
ployee which the school has neither licensed nor condoned explicitly or by implication, are excluded from this section.

\section{Comment}

The concept "substantial violation of law" is not free from ambiguity nor sliould it be. The system can tolerate, and even needs, play in the joints, so long as there is adequate procedural protection and judicial review.

The section is a plausible check on political abuses by extremist groups. ${ }^{88}$ Its main functions, however, are the policing of fraud on the state or consumer, enforcement of the various specific requirements of this Act, and the maintenance of safety standards. Of course, the penalty of decertification is supplementary to all other civil and criminal sanctions, in this Act and otherwise, which might affect the school and its personnel..$^{80}$

Section 3. The Supermtendent sliall have the authority and responsibility to decertify schools in accord with the standards of section 2 subject to the requirements of notice, hearing, and judicial review in the Administrative Code.

Section 4. After an order of decertification by the Superintendent ceases to be reviewable as of right by a court, the tuition account shall cease to be subject to withdrawal by such school pending a final accountmg. While the order remains reviewable, the right to withdraw funds from the tuition account shall continue in accord with article 14, section 1 , unless, upon apphication by the Superintendent to a court of general jurisdiction, an adversary hearing is held and a finding of fact entered that:

(a) There exists a probability that student withdrawals from the school will so diminish the account as to create a net obligation of the school to the state the payment of which obligation is not otherwise guaranteed, or

(b) The basis for the decertification is fraudulent conduct of which there is substantial unrebutted evidence.

\section{Comment}

In fairness to the school and in the interest of its students, the procedure would permit the school to qualify for the full amount in the tuition account until it has had a full measure of due process. However, subsection (a) would be necessary for

88. See also id. art. $10, \S 12$.

89. See, e.g., id. art. $13, \& 3$. 
those cases in which it appears clear that student defections by the year's end will have reduced the school's entitlement under article 13 below the level of its expenditure, and the school will be unable to cover its obligation to the state. Subsection (b) provides a similar protection to the state where the risk arises from the character of the school's management.

Section 5. The Superintendent shall have authority to stay temporarily a final order of decertification if necessary to prevent substantial hardship to pupils and innocent employees of a school.

\section{Comment}

It would be preferable in many cases to permit the school to wind up its affairs at the end of a school year rather than to cast the students and faculty adrift during the year.

Section 6. Before commencing the decertification process the Superintendent may informally determine whether the violation is admitted by the school. In such cases, where correction is possible and future comphance reasonably assured, the Superintendent shall permit the school promptly to correct the violation.

\section{Comment}

There is some risk of imposition by the Superimtendent but this seems preferable to making the process excessively formal and inflexible.

Section 7. The Superintendent shall administer the program established under article 15 of this Act providing guarantees to lending institutions of loans to schools in categories $\mathrm{E}$ through $\mathrm{H}$.

Section 8. The Superintendent is empowered in the areas subject to this Act to fix health and safety standards for schools in categories $\mathrm{E}$ through $\mathrm{H}$. This power shall be exclusive of all other authorities state or local. It shall be exercised through regulations of general effect which shall be subject to the approval of the Board. Such regulations shall permit the schools maximum flexibility consistent with safety and shall not generally forbid the operation of schools using multiple or varying locations or schools located in part or whole in private homes or any other class of building which can satisfy minimum safety requirements. 


\section{Comment}

Here is one resolution of a crucial issue that the legislature must face. The question is the rigidity of the safety standards for small private schools. One of the most interesting possible effects of the Act is the stimulation of mimi-private schools operated in homes or other small buildings, or which are peripatetic. The authors see this as a fruitful area for experimentation. This will require liberation of the schools from the cumulative, overlapping, and conflicting standards of the many local governments now empowered to regulate building design and use.

\section{Article 10 \\ POWERS AND RESPONSIBILITIES OF SCHOOLS IN CATEGORIES \\ A THROUGH H UNDER THIS ACT}

Section 1. No child in any school under this Act shall be required to engage in any act or ceremony with religious significance or to attend any class or course of instruction devoted primarily to the teaching of religion. The teaching of religion and all acts or ceremonies with religious significance are forbidden in all schools in categories $\mathrm{A}$ through $\mathrm{D}$; however, im sucli schools instruction concerning the social, historical, and cultural significance of religion may be presented in a fair and nonpartisan manner.

The amount to be entered for each child in the tuition account of a school offering religious imstruction shall be the estimated per pupil cost of secular education in such school, but in no case shall the amount credited exceed ninety percent of the tuition fixed by article 13 for that class of school. No school under this Act may allocate less than threequarters of its total cost to secular imstruction and the cost of all rehigious instruction shall be borne by the school. The Superintendent shall require such accounting from the schools as shall facilitate the enforcement of these limitations.

\section{Comment}

Three objectives require a delicate balance: The widest opportunity for parents to choose a sectarian or other ideological emphasis; protection for the religious and ideological liberty of all; conformity with the Federal and State Constitutions.

Simplistically, there are two forms of religious instruction: isolation and permeation-religion may be separated from other studies or diffused through all. Permeation makes better sense educationally, but isolation is easier to justify constitutionally (at least where the school excuses dissenters). However, neither is clearly valid even under the relatively tolerant views that seem to 
be ascendant today. ${ }^{90}$ Some discounting of the voucher and a mandatory dollar input by the school equal to the full cost of religious training seem minimum precautions. Under a permeation systein the accounting for such cost is a matter of additional difficulty. Nevertheless, we have decided to permit permeation in the interest of broadening the available options for schools and parents.

The provisions of this section and of article 14, section 2(7), should be read together. The latter article in theory permits unlimited amounts to be donated to schools for religious purposes, requiring only that such funds be the sole source of religious expenditure and that all religious expenditures be separately accounted for. However, article 10, section 1, puts severe practical limits upon this. First, the religious school can receive only $90 \%$ of the public dollars available to secular private scliools. Second, all state spending is conditioned upon the school's devoting at least three-quarters of its expenditure to secular instruction. This latter provision puts a practical maximum upon rehigious spending by forcing the school to operate at a loss-threatening its ultimate extinction-if it expends on religious instruction more than one-third the largest amount that may be credited for a religious school in its class ( $E$ through $H$ ).

An example may help to explain this. A class F elementary school ( $\$ 900)$, could receive at most $\$ 810$ in public funds for secular instruction if it also teaclies religion. Suppose that school then spends $\$ 270$ on religion. At that point, only three-quarters of its total cost $(\$ 1,080)$ would be secular. Thereafter, every additional dollar spent for religion would cost $\$ 3$ in additional secular services, and these secular dollars must come out of those general assets of the school which cannot be replenished except out of profits earned on tuition imcome. Thus, in order to teach more than $\$ 270$ worth of religion, the scliool must consune its own non-replemishable corpus.

There is an additional practical limitation upon the proportion of religious instruction. Article 10, section 12, requires at least four hours of secular instruction daily.

These structures are not all required by constitutional theory, but they help to promote a reasonable balance in curriculum and to diminish sonrewhat the serious problems of accounting inherent in the funding of institutions with mixed secular-rehigious purposes.

90. See, e.g., Walz v. Tax Comm'n, 397 U.S. 664 (1970); Board of Ëduc. v. Allen, 392 U.S. 236 (1968). 
There is a possible objection, on a free exercise basis, from the parent (and child) who, for reasons of his own, uses a religious school of a faith other than his own. However, assuming that admission is random and that a variety of schools is available, the dissenter in choosing such a school probably waives objection to a permeated curriculum. He may even waive objection to compulsory isolated instruction, though this seems unlikely. The dissenter surely does not waive his freedom to dissent, however, and the section protects him from compulsory acts or ceremonies contrary to his conscience.

Section 2. Schools in categories $\mathrm{E}$ through $\mathrm{H}$ shall notify the Superintendent at least 14 months prior to the opening of each school year of the maximum number of students the school will register and the estimated number of these that will represent students not previously enrolled in that school. Such information and similar information regarding schools classified $A$ through $D$ shall be contained in the information provided under article 7 , section 1 , by the office of the Superintendent to parents concerning schools accessible from their place of residence.

Schools in categories $\mathrm{E}$ through $\mathrm{H}$ may not enroll more than $105 \%$ of either such maximum enrollment or such estimated number of new students without permission of the Superintendent. Such permission shall be given only in the event that: (1) the school enlarges its staff and facilities $\mathrm{m}$ proportion to the additional number of students it wishes to enroll; or (2) the additional use of the facilities is temporarily necessary in order to provide places for all children in the area. In such latter event, the Superintendent shall immediately take steps to assure that enough additional staff and facilities will be available the succeeding year to eliminate the necessity for exceeding the announced maximum enrollments.

Schools in categories $\mathrm{A}$ through $\mathrm{D}$ shall admit students in numbers not to exceed $105 \%$ of the maximum number for each school announced by the Superintendent prior to the selection of schools by parents, except that the Superintendent may permit or direct such a school to admit additional students under the same standards applicable under this section to schools im categories $\mathrm{E}$ through $\mathrm{H}$.

\section{Comment}

The estimation, notification, and enrollment process for the transition period"should probably be spelled out in a separate 
section. ${ }^{91}$ The restraints upon enrollment are simply an effort to discourage consumer fraud. Parents should be able to depend upon the maximum enrollment announced by the school prior to the beginning of the selection process. The process for deciding whether an A through D school would admit an extra 5\% after its estimate had been reached would depend upon the scope and character of the limitations imposed upon the chief administrator's discretion through regulation. Absent regulation by the Superintendent, the chief administrator would make the decision whether to admit the extra $5 \%$.

Section 3. In the original selection process, the Superintendent shall assign to each school those applicants selecting such school as first choice. However, if the number of sucli choices exceeds a school's maximum enrollment under section 2, selection among these applicants shall be made by the Superintendent on a random basis. Each child not receiving his parents' first clioice shall be assigned by the Superintendent to one of the alternative choices in a manner respecting insofar as possible the parents' order of preference. Children not assigned to their chosen school in the original drawing shall be preferred for transfer if places become available in such school. A transferring student shall be entitled to placennent within the receiving school in the grade or, if either or both schools are ungraded, in the group most nearly comparable to that in which he had been placed in the school from which he transferred.

\section{Comment}

Much of the coinplex question of assignment to second and third choices would necessarily be handled by regulation. Various schemes are available to insure efficiency and fairness in an assignment process that is all the nore delicate for being an unwanted appendage to a free choice system in which first choice is missing.

The transferee's right to comparable placement is a protection against his de facto exclusion by the receiving school's threatening to set him back in grade or group level. The school, however, can withhold further promotion based upon his work after transfer in accord with article 21 . In an ungraded school the administration would have considerable flexibility both in the original assignment to a "comparable" group and in advancement thereafter.

Section 4. Schools under this Act shall have the authority to group students according to reasonable criteria for purposes of instruction.

91. See FCEA art. 7, § 1, comment. 
This may include non-graded groups. However, average spending per student between and among groups shall be substantially equal, and in no case shall the difference exceed fifteen percent of the lower figure except for differences arising from variation in salary of teachers due to semority and from the different expenditure schedules for children with varying lengths of attendance im articles 11 and 13. Where students with fewer and those with more than eight year's attendance since kindergarten are intermixed in one group, the permissible expenditure on such group shall be determined by the proportion of students in the group who fall in each expenditure category.

The provisions of this section notwithstanding, schools may set aside and einploy up to ten percent of the credit account in any year for experimental purposes. Such amount may not be used to supplement the support for programs already in the curriculum in a manner which would offend the provisions of the first paragraph of this section.

\section{Comment}

Traditionally the concern for equality of expenditure has proceeded no further than the school level. This section carries it to the class level, but not to the final level of the child-a step that seems impractical in the present state of the art. The equality motif here has a consumer orientation. Having chosen a particular spending level and shouldered the required tax burden, the family should be able to depend upon a substantial equality of treatment within the school. Note, however, that this Act does not guarantee even a minimum absolute spending level since there is no statutory restraint upon the margin of profit a school may take. The actual spending level would also be affected by the school's debt structure and other considerations. Obviously, limitations on profit and other similar restraimts could be legislated if desired.

Since no distinction is made in this section between kindergarten and other primary students, the section operates as a strong economic encouragement to improve kindergartens which usually run only half a day. Of course, kindergartens could still be run only half a day with the new dollars concentrated in whatever manner might be considered productive by the school.

The final sentence may be superfluous. It is intended to protect the equality objective of the first paragraph by frustrating any effort to use "experimental" funds merely to beef up the spending in a particular area of the regular program to the relative injury of the rest of the program. 
Section 5. Schools in categories A through $\mathrm{H}$ may contract with each other to plan and create facilities to be available to their students. The form and share of ownership and the right to use the facitity shall be fixed by contract. Rights of any school in such a facility may be assigned only to another school established under this Act.

\section{Comment}

This is an important section encouraging activities that no school could afford by itself, such as large gymnasia or the expensive common facilities of an educational park. The one complexity is the handling of schools of different spending classes in the same consortium. Should children whose parents make a lesser sacrifice have an equality of entitlement when it comes to use? Presumably this also would be handled by contract.

Section 6. The cost of all books, supplies, materials, transportation (other than to and from school under article 7, section 9), and all instruction, recreation, and related activities of schools under this Act shall be borne by such schools.

\section{Comment}

This is merely another protection against distortion of the system by differential cost impositions upon parents by the schools.

Section 7. Schools under this Act may by contract purchase educational services from other suppliers of educational services, public and private, except schools under this Act.

\section{Comment}

Permission for performance contracting in the schools anticipates a development that seems inevitable as well as desirable. It is not likely to become a large industry, however, unless poor parents are subsidized and permitted to purchase such special services directly, because the contractor's investment must remain very limited so long as there is a risk that a successful prograin will simply be taken over by the schools (customers) themselves. If the parent purchased the special service directly as a supplement to the basic schooling, the industry could afford to spend a good deal more in experimentation. A combination of family power equalizing for basic schooling plus a power equalized opportunity for the poor to contract with outside suppliers for special supplementary services-through the use of school stamps for example-deserves serious consideration. 
Schools formed under this Act would not be permitted to get into the educational contracting business as a sideline-or, a fortiori, as a primary activity. Such undertakings would at best risk the diversion of resources from the schools' own pupils. Of course, there is no barrier to the management and personnel of a school engaging in such enterprises where the funding is clearly separated from the school funds.

Section 8. Schools under this Act may extend the use of educational facilities in their ownership or control with or without compensation and in whole or in part to other schools under this Act or to any other entity for any use which does not interfere with the education of children enrolled in the school controlling or owning the facility. The incoine froin the leasing of such facilities may be retained by the school for such educational purposes of its students as it sees fit. However, where the lessee would be forbidden under article 14, section 2, paragraph (6) to make a grant to the school, the school may receive from such lessee no more than the cost of the use of the facilities.

\section{Comment}

This is an assurance that facilities will not be idle merely because of doubt concerning the power to license their use. Nor may they be leased at greater than arms length prices to friendly lessees.

Section 9. Schools may first qualify for a credit account for their students under articles 11 or 13 at the start of some school year after July 1, 1973. However, at any time schools in categories $\mathrm{E}$ through $\mathrm{H}$ may be certified and schools in categories $A$ through $\mathrm{D}$ may be designated so as to be included in the system of information under section 1 of article 7 and become eligible for selection by parents for future attendance.

\section{Comment}

The purpose here is to make entry to the system convenient to the schools without complicating inatters by allowing entry im the middle of a year.

Section 10. No action shall be taken or withheld by schools under this Act nor the rights or interests of any person affected by such schools based upon the race, color, nationality, or place of origin of any person or class of persons. No school shall deny any person any right, 
position, or opportunity, or cause him any disadvantage by reason of his or her sex.

\section{Comment}

Just how racial neutrality would work in the case of, for example, a Black Panther school is not certain, but the most important issues seem clear. Such a school could not exclude white students; nor could it exclude or discriminate against white faculty based upon their race, but it could screen any faculty applicant for his qualification as a teacher based upon his ability to contribute within the curriculum. Such distinctions are familiar if not always congenial to courts.

Note that, while sex discrimination is forbidden, not all distinctions based upon sex are invalid. There may yet be a role in our schools for separate facilities. Even separate but equal education for boys and girls within a school could be imagined, but the random admission requirement of this article, article 7 , section 1 , and article 13, section 9 would eliminate exclusively boys or girls schools. One may wonder whether this is an option that should not be retained.

Section 11. Schools in categories A through $\mathrm{H}$ shall be staffed by persons possessing the skills necessary to perform the educational and other tasks for which they are employed. For schools in categories A through D the Superimtendent with the approval of the Board may establish such miminum standards of skill for various tasks as he determines to be necessary and proper.

\section{Comment}

The teacher certification issue is here reduced to simple form reflecting the aims of the statute and, perhaps, the politics of education. The current California code requires private schools to be staffed by persons "capable of teaching." Attorney General has interpreted this to require ability comparable to that required for public schools but not to require the same credentials. ${ }^{23}$ In fact, there has been no real poticing of the quality of private school faculties by the state. Public schools teachers, of course, must meet rather elaborate credentials criteria. ${ }^{94}$

92. Cal. Educ. Code $\& 12154$ (West Supp. 1971).

93. [1941-1942] Op. CaL. ATT'Y GeN. NS 3965.

94. See, e.g., CAL. Educ. CODE $§ \S 13101-219$ (West 1969), as amended, (West Supp. 1971). 
The section would permit several outcomes. If collective bargaining were not a factor, schools, private and public, would hire the best persons they could attract, except to the extent the Superimtendent regulated the public schools. The section gives him the choice of leaving the A through D schools free to compete or of recreating the existing or even stricter credential requirements if he and the Board choose to do so. He might be impelled toward this by the pressure of organized labor for whom the centralizing of this power might prove an unexpected opportunity. There is even a possibility (risk?) that labor through collective bargaining might succeed in fastening credential requirements upon public and private schools on an industry- wide basis. For those inclined to be strict on credentials, hope under any funding system lies as much in the Luddite perspectives of labor as in the concern of the legislature. The outcome is quite unpredictable.

Section 12. Schools in categories $\mathrm{A}$ through $\mathrm{H}$ shall require each student for a substantial portion of his school loours in each year, from and imcluding the first grade through grade nine or its ungraded equivalent, to receive instruction in English, reading, and matheinatics. Instruction shall also be given regularly in health and physical education. The school day for each student above kindergarten shall include at least four hours of secular instruction. The Superintendent with the approval of the Board, may require sucli additional subject matter and such additional hours for schools in categories A through D as he shall determine to be necessary and proper.

No school under this Act shall encourage children to coinmit any criminal act or give instruction in the preparation for or performance of such act.

\section{Comment}

The specific requirements of this section were chosen rather arbitrarily. The general purpose is to open up options while retaining the "basics." However, it would be surprising if the Superintendent and Board did not require a good deal more than the statutory minimum in public schools. The private schools are less predictable. The existing private schools seem unlikely to change quickly froin the pattern established by the present more detailed statutory requirements. ${ }^{95}$ New schools, however,

95. CAL. Educ. Code $\$ \$ 8501-07,12154$ (West 1969), as amended, (West Supp. 1971). 
may take greater advantage of whatever curricular freedom is permitted.

The last paragraph is probably a political necessity. It may, however, be an unconstitutional limitation on expression and is probably undesirable as a matter of policy.

\section{ARTICLE 11 \\ POWERS AND RESPONSIBIIITIES OF SCHOOLS \\ IN CATEGORIES A THROUGH D}

Section 1. Schools owned and operated by the State under this Act (excluding the special schools described in article 7, section 10) shall be divided into four categories denominated A, B, C and D. Each category shall be defined by the number of dollars per pupil credited to the tuition account of the schools in such category. The Superintendent shall maintain such an account separately for each school on behalf of the students enrolled therein. For the school year 1973-1974, the ainounts to be credited to the tuition account for schools im each category per enrolled kindergarten student and/or other student who has attended school above the level of kindergarten for fewer than eight school years shall be as follows:

$$
\begin{aligned}
& \text { Category A- } \$ 600 \\
& \text { Category B- } \$ 900 \\
& \text { Category C- } \$ 1,200 \\
& \text { Category D- } \$ 1,500
\end{aligned}
$$

For the school year 1973-1974 the amounts to be credited to the tuition account for schools in each category per enrolled student who has attended school above the level of kindergarten for eight years or more shall be as follows:

$$
\begin{aligned}
& \text { Category A- } \$ 900 \\
& \text { Category B- } \$ 1,200 \\
& \text { Category C- } \$ 1,500 \\
& \text { Category D- } \$ 1,800
\end{aligned}
$$

The dollar amounts in these tables shall be diminished or increased each year thereafter by a percentage consistent with the standard overall price indices issued by the United States Department of Labor for the State of California as a whole.

\section{Comment}

Most of these basic provisions were explained in part I. The dollar anounts at the B level-and also at the $\mathrm{F}$ level ${ }^{96}$ are roughly equivalent to the magnitude of California expendi-

96. FCEA art. 11, § 1, art. 13, § 1 . 
tures under the present system, projected to 1972 (including capital costs). This allows for considerable inflation. Recall that the state under article 4 assumes the existing debts of school districts, in effect reducing the average cost to schools A through $D$ very substantially for several years to come.

It is questionable whether the spending distinction between elementary and high school pupils is sound. Indeed, the spending levels might well be made identical or even reversed to favor the younger children. The difference now appearing in the Act was included principally to express the traditional augmentation of spending in high schools and to demonstrate (in article 10, section 4) that the complexities caused by such a distinction in spending can be handled adequately.

Note that schools are free to organize at any level. For example, a grades 4-10 school could be fitted into the system. Nor is the scheme upset if the children are not assigned grades by the school since the section determines the "tuition" for each child according to the time he has spent in school.

Section 2. Each school in categories A through D may draw upon and obligate its tuition account subject to the limitations of article 14 and regulations of the Board. Each school shall account separately to the Superintendent for all receipts, expenses, and obligations, and such accounts shall be inade readily accessible to the public. All tuition accounts shall be closed out annually on June 30 and the balance therein, if any, remitted to each school.

Section 3. With the exceptions stated in this article, article 10 , section 8 , article 12 , section 2 , and article 14 , section 2 , all operations of each school shall be conducted by the chief admmistrator within the limits of the credit established in the tuition account, but where necessary and appropriate the credits in such accounts may be hypothecated in accord with the provisions of article 12 and regulations of the Board. ${ }^{97}$

ARTICLE 12

CAPITAL IMPROVEMENTS AND BORROWING BY SCHOOLS IN CATEGORIES A THROUGH D

Section 1. All new obligations of districts subject to this Act which by their terms are to be payable in whole or in part after July 1 ,

97. See id. art. $7, \S 5$, comment, art. $8, \S 4$, comment. See generally id. art. 14; see part I supra. 
1973, and the portion of those obligations whicl, if payable before that date, will not be exceeded by otherwise unencumbered funds of the obligor district, shall be subject to prior approval of the Superintendent. Such approval sliall be given or withheld in accord with regulations to be prepared by the Superintendent and adopted by the Board in accord with the general purposes of this Act.

The Superintendent may obligate appropriated funds for the maintenance, repair, and expansion of the physical plant of existing public scloools in areas affected by this Act until September 1, 1974. In each county affected by this Act he may select existing schools serving up to ten percent of the average daily attendance in the county for the year 1974-1975 and continue to provide in the same manner for their maintenance, repair, and expansion for one additional year. With that exception any school which by September 1, 1974, has been assigned to categories $\mathrm{A}$ through $\mathrm{D}$ shall after that date provide for such maintenance, repair, and expansion only out of its tuition account except to the extent specifically permitted under other sections of this Act relating to borrowing and additional income. However, in the formation of new schools A through D under this Act after September 1, 1974, the Superintendent may provide out of general funds for land and for mitial capital improvements and facilities to be conveyed to and owned separately and unencumbered by each sucli school prior to its commencing classes. The net value of land, improvements, and facilities, plus the net value of any other assets, real or personal, of schools in categories $A$ through $D$ shall not at any time exceed the maximum value per student fixed for sclools in categories $\mathrm{E}$ through $\mathrm{H}$ by article 13 , section 4 . Any such excess shall be eliminated by increase in permitted enrollment or by transfer of assets to the Superintendent or both.

\section{Comment}

These provisions are designed to limit both the power of districts to engage in a final spurt of improvenents for which the state will pay and also the Superintendent's opportunity to upset the relative power of the public and private schools. The state schools will have a substantial advantage to begin with in terms of existing plant. The section allows the Superimtendent some leeway to add to this advantage out of general funds for the most necessitous of the public schools. However, within 14 months after the system is in operation about $90 \%$ of the individual public schools will be dependent on their own tuition account for purposes of capital improvement; the remaining $10 \%$ will receive support for one additional year. The private schools will, of course, be on their own from the beginning, altliough, even there, certain additional limitations on capital are sug- 
gested. ${ }^{98}$ These same limitations on net assets are placed on public schools; their purpose and effect is discussed in the comment to the section cited.

Section 2. The chief administrator of any school in categories A through D may apply to the Superintendent for aid in the form of loan from such appropriations as shall be made available for that purpose, the proceeds of such loan to be used for purposes specified in the application. Such purposes may include any current or capital expenses arising from the continuation, expansion or alteration of the program of the school. The Superintendent shall approve such application if the loan requested would be commercially sound in the then current private market. Such loan if made sliall be repaid and secured upon the best terms available at the time of the obligation to borrowers in the then current private market for loans to scliools in categories $\mathrm{E}$ through $\mathrm{H}$. The Superintendent shall have no power to forgive any loan under this section and shall grant extensions only upon terms which would be commercially sound.

\section{Comment}

This is another device to keep the Superintendent from saving inefficient schools, but at the time to assure the availability of capital. The standard of commercial soundness should gain intelligibility as the system of capital formation for private schools begins to be utilized. The principal question left open is the standing of competing public or private schools to test the propriety of a loan made under this section.

There is at least some question about the equity of using the proceeds of loans to benefit one generation of students and requiring another in effect to repay them. The problem is endemic to existing systems and would require for its amelioration a clearer theoretical grasp and practical solution than the authors presently can muster.

Section 3. Schools in categories A through D under this Act shall be subject to the laws relating to insolvency and bankruptcy in the same manner as a private corporation for profit. The state shall not be responsible to any person for injury from any deficiency in the assets of such a school. To the extent that the school has become indebted to the State through loans or otherwise, the State shall be treated as a private creditor. Id.

98. See FCEA art. $13, \S 4$. These same limitations are placed on public schools. 


\section{Comment}

The statutory scheme depends upon the responsibility of the individual unit. The administration and faculty thus are insulated from economic and professional rescue by the state.

ARTICLE 13

THE CERTIFICATION, AUTHORITY AND RESPONSIBILITIES OF SCHOOLS IN CATEGORIES E THROUGH H

Section 1. Schools under this act owned and operated by private persons or organizations shall be divided into four categories denominated E, F, G, and H. Each category shall be defined by the number of dollars per pupil credited to the tuition account to be maintained by the Superintendent for the children enrolled in each school within the category. For the school year 1973-1974 and subject to the limitations of article 10 , section 1 , the amounts to be credited to tuition accounts for schools in each category per enrolled kindergarten student and/or other student who has attended school above the level of kindergarten for fewer than eight school years shall be as follows:

$$
\begin{aligned}
& \text { Category E- } \$ 600 \\
& \text { Category } \mathrm{F}-\$ 900 \\
& \text { Category } \mathrm{G}-\$ 1,200 \\
& \text { Category } \mathrm{H}-\$ 1,500
\end{aligned}
$$

For the school year 1973-1974 and subject to the limitations of article 10 , section 1, the amounts to be credited to the tuition account for schools in each category per enrolled student who has attended school above the level of kindergarten for eight years or more shall be as a follows:

$$
\begin{aligned}
& \text { Category } \mathrm{E}-\$ 900 \\
& \text { Category } \mathrm{F}-\$ 1,200 \\
& \text { Category } \mathrm{G}-\$ 1,500 \\
& \text { Category } \mathrm{H}-\$ 1,800
\end{aligned}
$$

The dollar amounts in these tables shall be diminished or increased each year by a percentage consistent with the standard overall price indices issued by the United States Department of Labor for the State of California as a whole. ${ }^{99}$

Section 2. Any person or persons or any organization in corporate form or otherwise which person or organization intends to operate a school in categories $\mathrm{E}$ through $\mathrm{H}$ under this Act, whether or not for profit, may make application to the Superintendent for certification and

99. These basic provisions are discussed in part I supra. 
designation for that purpose. Such application shall include a sworn stateinent containing all information required by existing statutes of private schools not subject to this Act plus the following:

(1) A description in detail of plans for meeting the requirements of this statute applicable to schools in categories $\mathrm{E}$ through $\mathrm{H}$.

(2) Indication of the specific category ( $\mathrm{E}$ through $\mathrm{H}$ ) in which the school will operate.

(3) The maximuin number of students to be admitted to the school in primary and in secondary grades or their equivalent.

(4) A detailed account of all existing and projected assets and liabilities of the school indicating that the net value of all assets of the school at the time of certification under this Act will not exceed the maximum value per pupil as established by section 4 of this article multiplied by the number of students specified in subsection (3) immediately preceding this subsection.

(5) A coinplete description of existing and projected plant and facilities of the school, which manifest compliance with applicable safety requirements.

(6) A description in detail of the qualifications of faculty hired or expected to be hired.

(7) A description of library facilities and collection.

(8) Dates and hours of attendance and holidays.

(9) Names of persons authorized to draw upon the tuition account.

(10) A statement of purposes, including religious, political, economic, or other emphases in instruction.

(11) Such additional information relating to the conduct of instruction as shall be reasonably required by the Superintendent.

Upon the completion of the application in proper form, certification shall issue froin the Superintendent unless, within four months of the date of application, the Superintendent shall properly reject the application in accordance with the standards set forth in article 9, section 1.

Where an application is based in whole or part upon action not yet completed, the Superintendent may issue a provisional certification which shall clearly state the conditions of final certification. Upon performance of such conditions final certification shall issue forthwith. Provisional certification sliall entitle a school to be treated as a certified school except that no credit may be entered in its tuition account, no 
parent of an attending child may be taxed for his attendance, and all publications and communications respecting the school must plainly state the provisional character of its certification. If the school fails to meet any condition of its certification, its provisional certification sluall cease. No liability of the state shall ensue for damages arising as a consequence of the failure of a school provisionally certified to receive final certification.

\section{Comment}

The substantive importance of the matters on which information would be required is dealt with in another section and the comments thereto. ${ }^{100}$ Note that the standards in article 9, section 1 for rejecting the application required in this section are very limited.

Section 3. Any person wlio intentionally makes a false statement of material fact in connection with an application for certification slall be punishable by confinement in a penal institution for not more than one year and a fine not to exceed $\$ 10,000$.

Section 4. No school sliall be eligible for certification if its net assets including the tuition account are in excess of the maximum value per pupil permitted under this section multiplied by the school's current maximum enrollable number of pupils. Such maximum value per pupil shall be $\$ 10,000$ modified in accord with the standards set fortl in article 11, section 1 and article 13, section 1 for the modification of the amounts to be credited to tuition accounts. Any certified school whose assets at any time exceed the aforesaid ratio shall either increase its permitted enrollment sufficiently to reduce the ratio to the level specified or shall divest itself of sufficient assets to achieve that effect. The Superintendent shall be authorized and required to withhold certification where necessary to achieve the objectives of this section and those of article 14. Such objectives include fair competition among all schools, neutrality in the assistance of private activity, and the reduction or elimination of the influence of wealth differences upon the spending of the schools under this Act.

\section{Comment}

The sections limiting the ratio of assets to maximum enrollment represent an uneasy resolution of a difficult issue. The need for soine sucli provision requires a clioice between what are

100. FCEA art. $7, \S 1$. See also the limited additional power under this article in section 4. 
probably adequate but extremely complex structures and structures which are less reliable but relatively simple. The latter were chosen, but enough may be said here to suggest how a thoroughgoing regulation of the problem might be attempted.

The problem basically is that, even with the income limitations of article 14, schools could achieve or have bestowed upon them advantages which would offend basic objectives of the system. Generally speaking this could happen in three ways:

(1) A school might be so successful as to accumulate earnings sufficient to assure survival irrespective of quality.

(2) The magnitude of original capitalization or subsequent endowments may assure survival irrespective of quality.

(3) A combination of No. 1 and No. 2 .

Such accumulations of capital, whether by public or private schools, would upset the competitive neutrality intended by the statute. In the case of private schools this evokes an additional objection; ideological interests which happen to be affluent could gain and/or sustain an advantage over neutral state schools and over other, poorer, private schools. The advantage would have been achieved by building upon a foundation of tuition income provided by the state itself, thus offending the basic proposition that wealth should not affect quality. The statute, in short, is designed to promote the competition of all ideas on terms as nearly equal as can be, not to provide a special public springboard for those ideas held by wealthy individuals.

Moreover, the state is not interested in helping to provide super-education for a very few students, especially if this is accomplished without regard to the tax sacrifice their parents are willing to undergo and irrespective of their scholastic promise. Schools that enter the system should be willing to make their facilities and assets work for a reasonably large number of children. A fair limit upon the pupil/asset ratio should not be harmful to education.

There are, of course, substantial balancing considerations that must also be given weight in drafting a statute. For example, there is a certain irony in limiting the right of a school to operate at a loss (one possible interpretation of section 4). Additionally, disinterested contributions to education ought generally to be encouraged. The authors have concluded, however, that the $\$ 10,000$ per pupil ratio will not inhibit contributions to schools that need them. If the share of such income for these 
poorer schools is increased by the use of this figure, there is on balance a probable gain. Moreover, the wealthier schools still can accept such assistance if they are merely willing to expand enrollment. There should be few cases of hardship caused by the limitation and few existing schools would be deterred from participation. However, only experience can give complete confidence that the proper figure is $\$ 10,000$ and a case could be made for fixing the ratio by regulation.

There may be an additional objection to the limitation because of its seeming punislıment of schools whose increase in assets is attributable to efficiency. There are several answers deserving elaboration, but they can merely be stated here. First, the evolution of economic giants would adversely affect competition in the inarket each serves and would ultimately injure the system as a whole. Second, such gigantism would rarely be the consequence of efficiency alone but would result more often from high capitalization plus some measure of efficiency. Third, the limitation suggested will at worst be harmless to the quality of education. Fourth, where the school is induced to increase enrollment, the effect is to make a successful model available to more children. Finally, where the school chooses divestiture there are several options available none of which is objectionable from a policy point of view. These include profit taking and the accunrulation of such spillovers for the eventual funding of another scliool.

Obviously cases can be imagined in the gray areas which would be troublesome if they were typical. For example, a 100 pupil school with $\$ 800,000$ in cash and $\$ 200,000$ in plant and equipment would have a distinct advantage over a thinly capitalized storefront school with 100 students. On the other hand, it will often be only because of the FCEA that operation of the storefront school will be possible. Indeed such operations are a primary beneficiary of any limit on the value of assets per pupil and their only objection is that the benefit is not greater.

If a private school prefers divestiture over expansion it may dispose of its excess in several ways through transfers without consideration. While other schools in the system associated with the school in any way could not qualitfy as a transferee because of article 14, the excessively wealthy school could pour the extra assets into a trust committed to the eventual establislıment of a new and separate school of the same general type. Of course, it could also pay the excess as a profit to the owners, im the case of a profit making school, or use it in any other lawful manner. 
Because of article 12, section 1, a public school which did not expand could only pay the excess to the state for further educational uses.

The specific power given to the Superintendent in section 4 is designed to combat evasions of the purposes of both this section and article 14. For example, a scliool could not simply liquidate and then reincorporate as two schools after receiving an endowment which would have exceeded the limitations for the single school. Likewise a school could not dissolve, receive additional assets from a source forbidden under article 15 and seek recertification as a new school. The Superintendent, treating each of these devices as a violation of the purpose of the statute would refuse certification.

Section 5. Schools certified by the Superintendent for operation in categories $\mathrm{E}$ through $\mathrm{H}$ shall comply with minimun standards of safety fixed by law and regnlation for sclools in categories A through D un. der this Act.

Section 6. Schools in categories $\mathrm{E}$ through $\mathrm{H}$ shall maintain such school records as shall be required by the Superintendent and shall make their students available for testing in accord with the requirements of article 7, section 12 .

Section 7. Schools in categories $\mathrm{E}$ through $\mathrm{H}$ shall mamtain such accounts as the Superintendent shall require and shall cooperate in the auditing of such accounts by the Superintendent.

Section 8. Schools in categories $\mathrm{E}$ through $\mathrm{H}$ shall maimtain an accurate record of enrollment and attendance and of excused and unexcused absences of all students and shall cooperate in the enforcement of this act and the truancy laws.

Section 9. Schools in categories $\mathrm{E}$ through $\mathrm{H}$ shall admit all apphcants subject to the provisions of article $10 .^{101}$

Article 14

LIMITATIONS UPON THE SOURCES OF REVENUE FOR SCHOOLS UNDER THIS ACT

Section 1. Every school under this Act may draw upon the tuition

101. See id. art. 7 , § 1, comment. 
account for such school under an efficient system to be established for that purpose by the Superintendent. However, from the date at which the account is credited with the tuition attributable to the fall enrollment until June 1 of the succeeding calendar year, a balance must be maintained in such account amounting to ten percent of the amount credited to the school on the basis of the enrollment on September 20. All tuition accounts shall be closed out annually on June 30 and the balance therein, if any, remitted to each school.

\section{Comment}

This mechanism is discussed above $\mathrm{e}^{102}$ and in part $\mathrm{I}^{103}$ The $10 \%$ balance is a protection of the state against diminution of the tuition account by withdrawals of large numbers of students during the year. As with other provisions, this section would need to be more flexible if the inodel is to encourage experimentation with unusual school calendars.

Section 2. Each school under this Act shall maintain records of all items of imcome or expense separate and distinct from those of any mdividual or organization whether corporate or otherwise. No school shall mix its funds with those of any other organization or those of any individual. No school under this Act may receive incoine other than credits from the tuition account except as follows:

(1) Costs reimbursed under contracts with the state under article 7, section 13.

(2) Adjustments in credit for geographical or other differences in costs of services as provided in article 7, section 4 .

(3) Income from leasing of facilities.

(4) Loans and loan guarantees under article 12, sections 1 and 2 and article 15.

(5) Grants or other payments from the federal government made directly to a particular school or through the Superintendent or other state officer.

(6) Grants from private sources having no connection either familial, financial, corporate, religious, political, or otherwise with the school, its management, or its pupils. This exception does not permit grants which directly or indirectly either would reward the school for the character of its social, economic, political, or religious training of students or would be used to promote indoctrination of students in particular social, economic, political, or re-

102. Id. art. $7, \S 2$, comment.

103. See text accompanying notes $37-50$ supra. 
ligious ideologies except as permitted in subsection (7) of this section.

(7) Support from any private source for current expense allocable to all forms of religious instruction and other religious activity in schools in categories $\mathrm{E}$ through $\mathrm{H}$, but such support must be earmarked for that sole purpose and segregated in a fund for religious expenditures separate from all other funds. Expenditures for religious purposes may be made only froin such fund. Each such expenditure shall be accounted for separately and specifically in a manner to be prescribed by the Superintendent. The school may not itself directly or indirectly make contributions to its religious purposes fund.

\section{Comment}

The general purpose is that explained in part $\mathrm{I}^{104}$ and in the comment to article 13 , section 4 . Both state and private sources are to be barred generally froin unfairly promoting their ideologies and from upsetting the equality of position established by the system by putting in extra money. However, an exception is necessary for religious schools. Since their state tuition accounts are reduced to make way for religious spending, they would be at a competitive disadvantage if they could not pay for the religious portion of their costs out of separate sources. The other exceptions are either concessions to economic reality (subsections 5 and 6); assurances that special compensatory and experimental needs can be met (subsection 1); devices to promote competitive equality (subsections 2 and 4 ); or of no consequence either way to competitive equality but intended to permit efficient use of resources (subsection 3 ). There is an unresolved question in subsection 6 whether prior family connections such as those of alumni should fall under the ban.

The potential role of the federal input is, of course, enormous. A great deal depends upon the form taken by that aid and the regulation which accompanies that aid. The statutory model here presented would require adaptation of the current federal programs which are keyed to school districts. Thus the California program would only proceed with a concomitant and responsible federal prograin that did not operate at cross purposes.

Section 3. Services perforned on a regular basis for schools under this Act at less than fair market value shall be reported to the Super-

104. See text accompanying notes $46-49$ supra. 
intendent in such form as he shall direct. The amount by which the market value of such services exceeds payment therefor by the school shall be deducted from the tuition account maintained for the children of such school. No person holding authority of whatever sort over an employee of a school under this Act shall in any manner, by threats, persuasion, or otherwise, attempt to induce such employee to dispose of any portion of the consideration paid for the services of such employee in any particular manner. Payments to any school for goods, services, rent, or other exchange shall be deducted from the tuition account to the extent that such payments exceed fair market value. Sales of goods to a school at less than fair market value shall be similarly treated.

\section{Comment}

The first paragraph would have its most obvious application in the case of a school staffed by teachers subject to vows of poverty and of obedience to authority. Similarly, the second paragraph is designed to prevent unauthorized gifts to the school, in this case in the form of excessive payments for goods or services. The last sentence of the first paragraph is a protection of those under vows of obedience or subject to similar constramts agaimst efforts of their superiors imdirectly to receive the benefit of free services.

The services of volunteer parents probably should not be counted against the tuition account. If the term "regular" appears to permit the opposite result, it should be made more specific. A similar problem is raised by the use of older students to teach younger; these too should be exempted. Otherwise, some ambiguity in the coverage seems desirable.

Section 4. Where any obligation of a school in categories $E$ through $\mathrm{H}$ is released without adequate consideration by a creditor whose relation with the school is in any degree noncommercial, the amount by which the obligation exceeds the value of the consideration given or promised for the release shall be debited to the tuition account. Repeated extension of an obligation without commercial justification shall be deemed a release.

\section{Comment}

This is merely an extension of the policy represented in the previous sections of article 14. Hopefully, it plugs another obvious loophole.

Section 5. The cost of professional services provided to any school 
under this Act by employees of any agency of state or local government, including the Department of Education, shall be reimbursed to the employing agency by the school. Such services shall include assistance in educational planning, technical assistance, legal counselling, architectural services and the like.

\section{Comment}

Although this section applies to all schools, its primary purpose is to keep distinct the line between the Department and the public schools-categories $A$ through $\mathrm{D}$-in the interest of equality of competitive position for all schools. The Superintendent is disabled from "lending" his staff to prop up a failing school.

\section{ARTICle 15 \\ INSURANCE OF FINANCIAL INSTITUTIONS MAKING LOANS TO SCHOOLS IN CATEGORIES E THROUGH $\mathrm{H}$}

Section 1. The Superintendent is authorized and empowered upon such terms and conditions as he may prescribe, to insure financial institutions which the Superintendent finds to be qualified by experience or facilities and approves as eligible for credit insurance, to the total face amount of $\$ 100$ million against losses which they may sustam as a result of loans and advances of credit, and purchases of obligations representing loans and advances of credit, made by them to schools in categories $\mathrm{E}$ through $\mathrm{H}$ of this Act for the purpose of financing alterations, repairs and improvements upon or in connection with existing structures, the purchase of existing structures, or the construction of new structures owned, leased, or to be owned or leased by such schools and used by them for educational purposes. Where the borrowing school is operated for profit, such insurance shall be limited to loans by the insured of not more than ninety percent of the cost of the repair or improvement.

Section 2. Any obligation with respect to which insurance is granted under this section may be refinanced and extended in accordance with such terms and conditions as the Superintendent may prescribe.

Section 3. Notwithstanding any other provision of law, the Superintendent shall have the power, under regulations to be adopted by the Board, to assign or sell at public or private sale, or otherwise dispose of, any evidence of debt, contract, claim, personal property, or security as- 
signed to or held by him in connection with the payment of insurance heretofore or hereafter granted under this article, and to collect or compromise all obligations assigned to or held by him and all legal or equitable rights accrumg to him in connection with the payment of such insurance until sucl time as such obligations may be referred to the appropriate State's attorney for suit or collection.

Section 4. The Superintendent is authorized and empowered to deal with, complete, rent, renovate, modernize, insure, or sell for cash or credit, in his discretion, and upon such terms and conditions and for such consideration as the Superintendent shall determine to be reasonable, any real property conveyed to or otherwise acquired by him in connection with the payment of insurance heretofore or hereafter granted under this article and to pursue to final collection, by way of compromise or otherwise, all claims against borrowing schools assigned by lenders to the Superintendent in connection with such real property by way of deficiency or otherwise.

Section 5. The Superintendent is authorized and empowered, under such regulations as the Board may prescribe, to transfer to any such approved financial institution any insurance in connection witl any loans whicl may be sold to it by another approved financial institution.

Section 6. The Superintendent shall fix a premium charge for the insurance granted under this article but such premium charge shall not exceed an amount equivalent to 1 per centum per annum of the net proceeds of the loan, and sucl premium charge sliall be payable in advance by the financial institution and shall be paid at such time and in such manner as may be prescribed by the Superintendent.

Section 7. The Board shall make such rules and regulations as may be necessary to carry out the provisions of this article.

\section{Comment}

This article is adapted from provisions of the United States Code establishing the power of the Federal Housing Administra. tion to insure financial institutions making certam loans for repairs and improvements. ${ }^{105}$ The permitted ratio of loan to value is increased here because of a presumed decrease in risk and the

105. 12 U.S.C. $\$ 1703$ (Supp. V, 1970). 
desire to encourage entrepreneurship; obviously, this is a question of judgment.

It is possible that these provisions should be extended to cover public schools under the Act. There may be instances in which it would be desirable for the state to guarantee the paper of its schools instead of making the loan itself. If an amendment so providing were adopted, it would be well to adopt the standard of commercial soundness of article 12 , section 2 , as a check upon the discretion of the Superintendent. The guaranteed loan could otherwise become a device for preference of the public school.

\section{ARTICLE 16 \\ A LEVY UPON THE INCOME OF PARENTS OF CHILDREN ATTENDING SCHOOLS UNDER THIS ACT ${ }^{106}$}

Section 1. In circumstances specified herein a tax shall be levied upon the income of those natural or adoptive parents of a child attending a school under this Act who are responsible for the support of such child. The parents subject to the tax shall be jointly and severally liable. However, any person who inarries a parent who is responsible for the support of such a child becomes responsible under this statute in the same manner as a natural or adoptive parent for the tax for such child's education jointly and severally with his or her spouse, to the exclusion of any other person, so long as the marriage endures and the child is in the custody of his or her spouse. Such tax shall be levied in all instances where in any calendar year a child enrolls in and attends a school organized under this Act and where there is as to such child a person responsible for the tax.

\section{Comment}

No more than two persons can be responsible for the tax at the same time but it is possible for one person or no one to be responsible. The latter condition obtains when no person is legally responsible for the child's support. In that event, under article 6 , the person or institution having custody chooses a school for the child.

It is arguable that the tax responsibility peculiar to parents would tend to chill enthusiasm for the adoption of children. This could easily be averted by taxing only natural parents. This alteration would presumably stimulate adoptions by persons who are not already parents of school-age children. For those who

- 106. The general objectives of this special educational tax are explained in part I. See text accompanying notes supra. Its probable effects are explored in part III infra. 
are (with a minor exception affecting wealthy families under section 2) the tax liability as the provision now reads would not be altered in yearly amount by an adoption, but, depending on the respectives ages of the natural and adopted children (for example, if the adopted child were youngest), it could be prolonged. For those with no children school-age or younger, the prospect of tax-free parentage througli adoption might prove a mild stimulus to population control.

Section 2. The tax levied under this article shall be some portion of the taxpayer's adjusted gross income as that income is calculated under the provisions of the Internal Revenue Code. The tax shall vary according to both adjusted gross income and the category of school (A though $\mathrm{H}$ ) attended by each child. The relation between income of the taxpayers, the category or categories of school attended by their child or children, and the tax shall be that set forth in Tables I-III below, except that in no event shall the amount of the tax exceed one and one-half times the sum of all the amounts credited to tuition accounts by reason of school attendance by all the children for whom a taxpayer is responsible. Where a parent is responsible for the tax due for a child's attendance, but where the power to choose the school to be attended by such child is held by an institution or person not subject to the tax, sucli parent shall not be responsible for a tax greater than that fixed for schools in categories $\mathrm{B}$ and $\mathrm{F}$.

Table I

Adjusted Gross Income of Parents Under $\$ 3,500$

Category of School Attended

$A$ or $E$
$B$ or $E$
$C$ or $G$
$D$ or $H$
Amount of $\operatorname{Tax}$

$\$ 5$

$\$ 10$

$\$ 15$

$\$ 20$

Table II

Adjusted Gross Income of Parents $\$ 3,500$ or More, but Less Than $\$ 12,000$

Category of School Attended
$A$ or $\mathrm{E}$
$B$ or $\mathrm{F}$
C or $\mathrm{G}$
$\mathrm{D}$ or $\mathrm{H}$ :

Amount of Tax

$\$ 5+2.3 \%$ of incoine above $\$ 3,500$

$\$ 10+3.5 \%$ of income above $\$ 3,500$

$\$ 15+5.1 \%$ of mcome above $\$ 3,500$

$\$ 20+6.9 \%$ of income above $\$ 3,500$ 
Table III

Adjusted Gross Income of Parents $\$ 12,000$ and Above

Category of School Attended
$\mathrm{A}$ or $\mathrm{E}$
$B$ or $F$
C or $\mathrm{G}$
$\mathrm{D}$ or $\mathrm{H}$

Amount of $\operatorname{Tax}$

$$
\begin{aligned}
& \$ 200+3.0 \% \text { of mcome above } \$ 12,000 \\
& \$ 310+4.2 \% \text { of income above } \$ 12,000 \\
& \$ 450+5.8 \% \text { of income above } \$ 12,000 \\
& \$ 610+7.6 \% \text { of income above } \$ 12,000
\end{aligned}
$$

Where a taxpayer is responsible under this Act for the tax due for the education of more than one child, the amount of such tax shall be the average of those amounts that would be due for each child if he were the only child whose attendance in school were the basis for such taxpayer's liability. When a child enrolls in and attends schools in different tax categories in the same calendar year, the amount of the tax attributable to that child shall be pro-rated according to the nunber of days he is enrolled in schools of each tax category under this statute. The tax rate for this purpose shall be counted as zero for those school days for which the child was not enrolled in any school under this Act.

Where no school of the category chosen by the person or institution having responsibility for such choice under article 6 is available, the tax rate shall be that fixed for the school actually attended by the child in cases where the amount to be credited the tuition account for that school under this Act is less than that for the school selected; but in no case shall the tax rate exceed that applicable to the most expensive category of school represented among the three alternative schools chosen for the child under article 6 , section 1 , and article 7 , section 1 by the person or institution responsible for that choice.

The tax shall become due and payable in the same manner and at the same time as the general tax upon income earned during the calendar year in which the child or children were enrolled in and attended a school or schools under this Act.

\section{Comment}

The federal income tax is employed as the standard for adjusted gross incoine in order to simplify the case of the new California resident. The educational tax should be based upon his total income for the year, a result which would require additional language if the California income tax provisions were the standard. Note that in April the taxpayer pays the tax for the attendance by the child during the prior calendar year. There is a question as to whether this is the optimal tax year. Among other things the delay in payment until the following April may raise revenue problems in the transitional year. However, these 
are likely to be offset by the final collection of local educational property taxes. ${ }^{107}$

A discussion of the economic impact of the tax as structured here compared with the burden of the present system appears in part III. There are, of course, numerous imponderables concerning the total cost of the system to families and to the state. For example, the net contribution of taxpayers will be affected by the continued deductibility or non-deductibility of state taxes (including the self-tax) on federal returns. However, by making certam assumptions, a fair idea of its effects upon specific classes of persons can be described with some confidence. With regard to the net contribution of families a note of caution is in order. Although the rates in this section may appear steep in some instances, they cannot be judged by standards appropriate to taxes designed to raise revenue. Like every other part of the system they should be evaluated only in terms of their contribution to its complex purposes. Insofar as the system is a method for selling educational services, it may be judged as a market. So viewed, it is necessary to probe not merely the tax cost to a family, but also the benefits which that cost purchases. Even if the Act does not improve the relative lot of rich parents in either respect, it clearly is an enormous bargain for the consumer of education who is poor; and the extent of the bargam is multiplied by the number of children. If this suggests a Malthusian monster, there are numerous protections available, but that is not our present concern.

Finally, note that the decision to impose the tax even upon families using the cheapest schools is not required in principle. Attendance could be free at the minimum spending $\mathrm{A}$ and $\mathrm{E}$ levels. Nevertheless, there may be an important psychological advantage in charging. Poor parents who are unused to exercising choice thus can be brought to focus upon the fact that they hold a living and valuable option and must exercise it. If the $A$ and $E$ schools were free, there might be a tendency to choose them without serious reflection upon alternatives. As a secondary rationale, it could also be said that -in a very rough waythe consumer is asked to help pay for the purely private benefits he receives from education.

Nevertheless we have developed an alternative set of rates which has as its base a free school at the $A$ and $E$ levels. These rates are as follows:

107. See FCEA art. 4, § 3 . 
Income level: A. $\$ 0-\$ 3,500$
$\mathrm{A} / \mathrm{E}-\quad 0$
$\mathrm{B} / \mathrm{F}-\$ 6$
$\mathrm{C} / \mathrm{G}-\$ 13$
$\mathrm{D} / \mathrm{F}-\$ 20$

B. $\$ 3,500-\$ 12,000$
$\mathrm{A} / \mathrm{E}-\quad 0$
$\mathrm{B} / \mathrm{F}-\$ 6+1.4 \%$ above $\$ 3,500$
$\mathrm{C} / \mathrm{G}-\$ 13+3.7 \%$ above $\$ 3,500$
$\mathrm{D} / \mathrm{H}-\$ 20+6.9 \%$ above $\$ 3,500$

C. $\$ 12,000$ and up
$\mathrm{A} / \mathrm{E}-\quad 0$
$\mathrm{B} / \mathrm{F}-\$ 125+2.1 \%$ above $\$ 12,000$
$\mathrm{C} / \mathrm{G}-\$ 330+4.4 \%$ above $\$ 12,000$
$\mathrm{D} / \mathrm{H}-\$ 610+7.6 \%$ above $\$ 12,000$

Section 3. Any person who pays or offers to pay to another in exchange for the enrolling of a child in a particular school any part of a tax paid under this article or any part of a tuition credit received by a school under article 13 of this Act shall be punishable by confineinent in a penal institution for a period not to exceed three years.

\section{Comment}

This is merely an anti-kickback section. Presumably schools will be tempted to buy (and parents to sell) pupils for a portion of the tuition credit. No doubt there are schools and parents who would succumb.

\section{ARTICLE 17 \\ THE PROTECTION OF PUPILS' PRIVACY}

No school under this act shall inquire concerning the economic circumstances of the parents of any child except insofar as necessary in the course of providing counseling or special treatment to such child as a consequence of plainly manifested educational need.

ARTICLE 18

NOTICE, HEARING, AND REVIEW OF ADMINISTRATIVE ACTION

All action of the Superintendent, the Department of Education, and the Board of Education under this Act shall be subject to the provisions for notice, hearing, and review of the Government Code.

\section{Comment}

Specific protections against administrative caprice are sprinkled throughout the Act. The additional protections of the 
current $\mathrm{Code}^{108}$ may be adequate, but the authors do not represent that they have foreseen and provided against every hiatus. Perhaps, for exainple, the standing of parents to challenge administration action should be specifically tailored rather than left ambiguous.

\section{ARTICLE 19}

DISCIPLINE OF STUDENT MISCONDUCT

Section 1. A student may be suspended from attendance at or instruction in any school or any class within any school under this Act for conduct during school hours which is either unlawful, dangerous to that student or to others, or which deliberately interferes with the learning process. A student may also be suspended for a temporary physical infirmity or disease which makes him a substantial physical danger to others. Suspension shall be imposed only by the pupil's teacher or by an administrator or body charged specially with such responsibility by the school. Suspension by a teacher shall not exceed two days for any act, course of conduct, physical infirmity, or disease. The period of suspension by an administrator or body charged with such responsibility shall not, for any act or course of conduct, exceed five school days in addition to the period imposed by a teacher, unless, within the fiveday period, notice of expulsion proceedings is given. In the latter case suspension may continue for ten days after the expiration of the five days or until decision is rendered in suclı proceedings, whiclever period is shorter. If suspension is based upon infirmity or disease, it shall not exceed the period during which an infirmity or disease causes the student to be a substantial physical danger to others. Suspension in excess of two days shall not be imposed without 24 lours notice to the pupil and his parent or guardian and an opportunity for the pupil to appear with or without parent or guardian before the administrator or body charged with such responsibility and to offer reasons suspension should not be imposed. No judicial review of the decision of such person or body may be had in suspension cases unless, $m$ the case of repeated or prolonged suspensions, evidence is offered tending to prove an intention of the school to force the pupil to transfer. ${ }^{109}$

Section 2. A student may be expelled from any school under this Act if he has engaged in conduct directly related to the school which is seriously unlawful, creates a substantial risk of serious imjury to other persons in the school which risk was known to sucl pupil, or materially

108. See generally CAI. Gov't CODE $\S \S 11500-29$ (West 1966).

109. See FCEA art. 19, § 2, comment. 
impairs the education of other pupils in the school. However, in no case shall a pupil be expelled unless there is evidence that such or similar misconduct is likely to be repeated. No pupil shall be expelled without ten days written notice of the conduct charged, the persons bringing the charge, and the evidence against him. He shall be afforded a hearing before an arbitrator to be agreed to by the school and the parents. If the parties fail to agree on an arbitrator, the school shall forwith make application to the American Arbitration Association for the appointment of an arbitrator. The parties may be represented by counsel before the arbitrator, and a verbatim transcription of the record shall be taken and preserved. The costs of the arbitration and the transcript shall be borne by the school.

A student who is expelled shall not be entitled as of right to enroll in a school under this Act for a period of one year. If during that period no school under the Act will accept such pupil, the Superintendent shall provide for his education in a school for this purpose to be maintained separately from the schools under this Act. At the end of such period the pupil sliall be eligible in the same manner as any other pupil to enroll in any school under this Act unless, upon written notice by the Superintendent to the pupil and his parents and after opportunity for hearing before an arbitrator chosen by the parents and Superintendent in the inanner previously provided in this section, it is determined that the pupil is not rehabilitated. Thereafter, upon petition of the student or his parents, such pupil shall be eligible for yearly review by the Superintendent of his exclusion from schools under this Act.

\section{Comment}

Aside from the fairly demanding criteria for a valid expulsion there will be an additional disincentive for many schools to abuse the power of expulsion: Under article 7, section 2, departure of a student represents a loss of revenue. Schools with waiting lists for transfer are obviously the primary targets of the provisions of this article. Such schools have an incentive to prune from their student body those consumers who tend to impair the quality of the product. This tendency is accentuated in a market setting. In fairness to the pupil and to other schools the power of a school to force its customers to move should be limited. The provisions relating to suspension and expulsion attempt, therefore, to limit arbitrary discipline while assuring administrative flexibility. The lines drawn here for all schools are much as we would expect them eventually to be drawn for public schools throughout the United States by the courts and legislatures. Of course, special provisions are required to govern reinstating the eligibility of an expelled student to enroll in A through 
$\mathrm{H}$ schools. It would be undesirable to permit a student expelled one day to enroll as of right the next day in any A through $\mathrm{H}$ school with an opening.

ARTICLE 20

EXCLUSION OF STUDENTS FOR INCAPACITY TO BENEFIT

A school may terminate the enrollment of any student whose physical, mental, or emotional condition requires his enrollment in a special school in order for him to benefit from education. Any such termination shall be subject to the notice and arbitration provisions of article 19 , section $2 . .^{110}$

\section{ARTICLE 21}

WITHHOLDING PROMOTION FOR FAILURE

TO MAKE ACADEMIC PROGRESS

Schools under this Act may withhold promotion from any student, and/or require the repetition of work by any student, who has failed during any year to make sufficient academic progress. Such student shall be entitled to a review of his record by a committee of three faculty meinbers to consist of one member selected by the parents of such child, one member selected by the school, and the third selected by the other two. The student and his parents shall be notified in writing of the right to a review of the student's record by such a committee. The student and his parents shall have the opportunity to be heard informally by the committee and to submit such evidence as they wish in his behalf. The committee may alter the previous decision of the school in favor of the student in whatever manner it deems to be in the best interest of the pupil.

\section{Comment}

This is simple but significant. Schools inay not "flunk out" students simply because they do inadequate work. There would, of course, be a strong tendency for popular schools to do so; the result, if unprevented, would be either a game of musical chairs (if flunkees were privileged to enroll wherever else there was rooin) or else the creation of schools specializing in flunkees. This latter result would not be obviously undesirable if these students were reasonably uniform in their level of capacity or their indolence. That is, special schools for low performers are a common phenoinenon and are defended by some on pedagogical grounds. The more substantial objection is that each school would apply a standard of minimum acceptable work which

110. See id. art. $7, \S 10$. 
would become higher as the length of its transfer waiting list increased. The problem of stigma is also very serious, and, on the whole, it would be preferable to eliminate the opportunity to flunk students from school.

On the other hand, the course chosen in the statute would lead inevitably to tracking within the school. The dilenma posed is endemic to voucher systems, but the result is no worse than the current system in which extreinely low performers are purged from the private schools. At least under the approach taken here the private institutions will share the burden of educating such students. No doubt there would be efforts by such schools, as there are by public schools today, to oust students through the mechanism of article 20 . If the procedural protections are adequate, the danger is controllable.

Note that this section would have no practical effect upon nongraded schools except for purposes of graduation. 


\section{III}

\section{ECONOMIC AND TAX ANALYSIS}

The three sections in this final part are devoted respectively to setting the article 16 tax rates and the articles 11 and 13 tuition credit levels under the FCEA; estimating the gross and net burden on California families of the current system of property taxation for schools projected to 1972-73; and speculation concerning the potential cost and revenue dimensions of the FCEA. These sections illustrate the kinds of analysis that are a precondition of serious political attention to the FCEA or, for that inatter, to any basic reform in the system.

\section{A. Setting the Article 16 Tax Rates and the Articles 11 and 13 Tuition Credit Levels}

The Family Choice in Education Act is designed simultaneously to shift society's delegation of decisionmaking about education finance from the local school district to the family and to make the financial burden of education imposed on a family reasonably related to a combination of each family's ability to pay and the category of school expenditure it chooses for its children. These twin objectives of fiscal decentralization and fiscal reform require appropriate tax rates for article 16 and specific dollar levels of tuition credit for articles 11 and 13 of the Act. Setting rates and spending in turn requires an inquiry into existing fimancial patterns and estimates of future behavior. The purposes of this section are to report the approach taken by the authors in selecting specific numbers for the Model Act and to suggest questions to which the legislature must be sensitive in considering its adoption. Of course, the tuition credit amounts and tax rates employed in the Model Act should be treated only as illustrative. Taking into account the factors discussed below (and perhaps others) and equipped with better data, the legislature might select a rather different looking set of tax and spending tables.

\section{The Baselines: Setting the Amount of Tuition Credit for $B$ and F Schools}

As a starting point, in their first year of operation, the $B$ and $F$ category of schools should enjoy a tuition credit ${ }^{111}$ —or cost to the state-approximately equal to the predicted statewide average spending per pupil for all school costs for that initial year assuming the present system and present trends. The Model Act is designed to become operative in a specific year-the 1972-73 school year-which will thus be

111. FCEA art. 11, $\S 1$, art. $13, \S 1$. 
the focus in illustrating the kinds of forecasts which the legislature will have to make. In 1968-69 the average total spending per pupil in California was $\$ 640$ in elementary school districts and $\$ 880$ in high school districts. ${ }^{112}$ The average per-year dollar increase during the five years ending in 1968-69 was $\$ 45$ in elementary districts and $\$ 52$ in high school districts. If the five-year trend is projected, average perpupil spending levels of $\$ 820$ in elementary districts and $\$ 1,088$ in high school districts can be expected in the year 1972-73.

An alternative basis of prediction is the five-year average-for the five years ending in 1968-69-percentage increase in spending experienced by elementary districts $(9.65 \%)$ and by high school districts $(6.65 \%)$. If this method is used spending levels of $\$ 925$ and $\$ 1139$, respectively, are predicted in 1972-73.

Using these two slightly varying sets of predictions and taking into account the fact that perhaps unified school districts are spending somewhat more ${ }^{113}$ the authors have settled on $\$ 900$ for elementary schools and $\$ 1200$ for high schools as the tuition credit amounts for B through $F$ schools under the Model Act. These amounts respectively represent increases of $41 \%$ over the $1968-69$ elementary district average spending per pupil and $36 \%$ over the 1968-69 high school district spending per pupil. The tuition credit level amounts chosen should not be taken as a commitment to the propriety of spending more on the higher grades; rather, the continuation of present patterns of difference has merely been assumed for purposes of illustration.

Note that pegging B and F schools to the predicted 1972-73 average means that families will be able to choose to send their children

112. Division of School Admin. and Fin., Cal. Dep't of Educ., California Public Schools, Selected Statistics, 1968-69, at 73 (1970) [hereinafter cited as SELECTEd Statistics]. The school data for the year 1968-69, set in the text and footnotes in part III, are from or based on Tables IV-1 to IV-4, id. at 73-114.

113. Unified districts spent $\$ 738$ per pupil in $1968-69$ on all their pupils-as compared with $\$ 640$ per pupil in elementary districts and $\$ 880$ in high school districts. Assuming that unified districts spend $37.5 \%$ more on high school pupils than elementary pupils-this is based on spending $\$ 800$ in elementary districts and $\$ 640$ in high school districts-and assuming that unified districts have 2.19 times as many elennentary school pupils as high school pupils-this figure is based upon 1968-69 statewide elementary district total average daily attendance (ADA) of 1,132,993 and high school district total $\mathrm{ADA}$ of 518,317-an estinate of kindergarten through 8th grade and 9th through 12th grade spending in unified districts can be made. The authors' calculations yielded estimated spending in unified districts of $\$ 660$ per eleinentary pupil and $\$ 908$ per high school pupil, or slightly above the separate district amounts (although there is a problem regarding junior college pupils lurking in the data that may be making the estimates for unified districts too high, but which is not worth going into here). Note that unified districts account for more than $60 \%$ of California pupils in public schools grades kindergarten through twelve. A desirable refinement of this analysis would discriminate between the statewide average and the average for urban areas of the sort likely to be selected for experiment. 
to schools obtaining tuition credit in an amount that approximates that average, an amount below that average (the tuition credit for $\mathrm{A}$ and $\mathrm{E}$ schools) or two amounts above (the tuition credits respectively for schools $\mathrm{C}$ and $\mathrm{G}$ and $\mathrm{D}$ and $\mathrm{H}$ ). This approach combines the realities as to likely spending levels under the Act with a personal preference for the possibility of a greater commitment of funds for education.

\section{The Baselines: Setting the Taxes for $B$ through $F$ Schools}

Having established the B and F schools' tuition credit amounts, the appropriate self-tax rates for those schools to be used in article 16 must be considered. There are a number of criteria. First, poorer families should not make a contribution through the article 16 tax rate which is, in proportion to their income, more than that made by richer families choosing the same category of school. That is, there is to be sharp contrast to the present pattern in which the poor pay proportionately more. ${ }^{114}$ The tax structure chosen for $\mathrm{B}$ and $\mathrm{F}$ schools should reasonably approximate this objective. Second, and more difficult to quantify, the rates should require the user family to pay through the article 16 tax its "fair" share of the cost to society of the category of schools it selects. Note that the concept of fairness employed includes an assumption that, as a general rule, all user families of the same income class are to be treated similarly regardless of the number of children they enroll. In all candor, it is difficult to decide abstractly what is a "fair" amount for the article 16 tax for B and F schools for a family with, for example, $\$ 12,000$ of adjusted gross income (AGI). It is relevant-but how relevant?- that the family will also be paying toward schools through state taxes which support elementary and secondary education. It is relevant-but how relevant? - that society as a whole benefits from educating its members and should pay for part of the cost.

In view of these criteria, the $B$ and $F$ rates have been arranged in three steps. First, the rate structure was based upon the current norm-the typical family, which in 1972-73 is predicted to have a $\$ 12,000$ AGI. Second, since the article 16 tax would replace local school property taxes on residential property, the new burden for $B$ and $F$ schools was made to approximate the "old" burden-the average 1972-73 burden upon the typical family through local school property taxes under the present financing system. Third, using the $\$ 12,000$ AGI family tax rates as starting points, we have calculated article $16 \mathrm{~B}$ and $\mathrm{F}$ taxes for other income levels. Each step of this process is set out in the following subsections.

114. See text accompanying notes 151-52 infra. 


\section{a. Predicted 1972-73 income of a typical user family}

In predicting the income of the typical user family the most difficult problem is determining the appropriate measure of income. A number of choices are possible, imcluding adjusted gross income, taxable income, and family personal income both before and after federal taxes. The reason for selecting adjusted gross income deserves some comment. On equity considerations alone, some notion of family personal income might be preferable, particularly since it includes some factors which mcrease econornic well-being but are not included in AGI. However, to make the Act adininistratively feasible, it was necessary to use some familiar income concept. This narrows the clioice to AGI and taxable income, since these are the only two necessarily calculated for federal and state tax returns.

Arguably, taxable mcome is a better measure of economic wellbeing than is AGI, since the latter leaves out of account certain personal and tax deductible expenditures such as medical costs, ${ }^{115}$ and exemption amounts for taxpayers and dependents-at least in the case of the federal concept. ${ }^{116}$ However, this argument fails for a number of reasons. In order to determine taxable income, AGI is in effect reduced by certain voluntary contributions-sucl as charitable contributions ${ }^{117}$ — which should not diminish the article 16 tax. Similarly, it is as undesirable to reduce the article 16 tax if a family has more than one child-because of exemptions it claims-as it would be to increase it. ${ }^{118}$ Moreover, while the state and federal AGI concepts are adequately consistent with one another, the taxable income concepts are not. This would make using taxable incone far more cumbersome in setting the rates. Finally, in general, there is better data available based on AGI. Note that having settled on AGI, it is used both in the rate tables for article 16 and as the basis for the analysis in getting to those tables. This was practically but not theoretically required.

Having selected the measure of income, the prediction itself involves little complication. Based on adequate information supplied by the Franchise Tax Board, the median California family AGI in 1972-73 should approximate $\$ 12,000{ }^{119}$ This figure has been taken as the projected incoine level of the "typical family." Median family AGI will

115. Cf. INT. Rev. CoDE of 1954, $\$ \$ 62$ (defining AGI), 63 (defining taxable income). Regarding treatment of medical costs, see id. $\S 213$.

116. Id. $\$ \$ 63,151$.

117. Id. \$\$ 63,170 .

118. It should be emphasized that the tax is a family tax: the rate does not change regardless of the number of children enrolled. FCEA art. 16, $\$ 1$.

119. The median AGI for all state tax returns in 1968 was $\$ 8,865$; the mean was $\$ 10,676$. CAL. Franchise TAX BD., ANN. REP. $7-8$ (1969) (dealing with the 1968 income year). While the inedian for joint returns was not calculated by the Franchise Tax Board, information contained in the Report allowed the authors to coin- 
be used rather than the mean-arithmetic average-since the mean overstates the income of a typical family by giving undue weight to the few very high income families. A difficulty still presents itself. The typical family for purposes of calculation is one with children of school age. Available data, however, does not separate such families from all families. Thus it is necessary to assume that the income of such famihes will be about that of all families.

\section{b. Setting article 16 tax rates for $B$ and $F$ schools for the typical family}

(i) Projection of the 1972-73 average burden of the present local school property tax on $\$ 12,000$ AGI families. The major objective here is to predict the 1972-73 local school property tax burden on the $\$ 12,000$ AGI family; such burden will then be used as the basis for the article 16 tax to be imposed on the families choosing either B or F schools. Determining how much families of various income classes pay in property taxes for elementary and secondary education is not a simple task. It requires a progression of steps and assumptions that make our final figures ball park estimates. Moreover, it must be kept constantly in mind that, depending on its place of residence, a family with AGI of $\$ 12,000$ a year today may pay for example, $\$ 100$ in school property taxes and have its children attend schools that spend $\$ 900$ a year per pupil; or it may pay $\$ 400$ in school property taxes and have its children attend schools that spend $\$ 700$. The Model Act is designed to eliminate the influence of variations in school district wealth; hence, the impact of the present systein is not pursued on a district-by-district basis, nor are local taxes paid compared with spending. Rather, the average impact of the school portion of property taxes was sought on a statewide basis.

The procedure was as follows: Since only a portion of property taxes goes to education, the average portion of each dollar raised on a statewide basis that was apphied to elementary and secondary schools was determined. Then, the burden of the school property tax on the family was calculated with a necessary distinction being made between homeowners and renters. ${ }^{120}$ Looking at the property tax in this way gave the average gross dollar contribution to education of homeowner families and all renters by income class. Next, the effect of state and

pute the mean for joint returns for 1968. This was $\$ 12,460$. See id. at 51 . If the same dollar difference exists between the respective medians-all returns as opposed to joint returns-as it does between means, the median AGI for all joint returns in 1968 conld be estimated at $\$ 10,649$. In light of past increases and continued inflation, a prediction of a median family AGI of $\$ 12,000$ for 1972-73 does not appear to be unreasonable. Indeed, in discussions of this prediction with personnel at the Franchise Tax Board, it was pointed out that $\$ 12,000$ might be somewhat low.

120. The indirect nature of the renter's property tax payments-they are the result 
federal policies allowing tax deductions for specific taxes was examined. As a result, the gross contribution figures first calculated were modified to reflect the net cost to the taxpayer after allowing for the tax offsets. In most instances current data or recent state studies and reports were obtainable and were used; in some places rather old information had to be relied upon. Based on previous patterns in a given area, the data were then projected to give an indication of what the picture would be in 1972-73 if recent trends and practices continue. The detailed analysis and the specific assumptions and coinputations appear in section B of this part of the Article.

The results of the inquiry into the burden of the local property tax on homeowner families, described in detail in section B, are summarized in Table III-A-1, ${ }^{121}$ which shows by AGI class, estimated for 197273 , both gross and net-after tax offset-contributions made to elementary and secondary schools through local property taxes by hoineowner families. Because of their lack of coinparability and their unreliability, and because they were not used specifically in setting the article 16 rates, the data as to renters ${ }^{122}$ are not reported here.

\section{Table III-A-1}

California homeowner families: gross and net contribution to elementary and secondary education through the property tax projected to $1972-73$

\begin{tabular}{|c|c|c|c|c|c|}
\hline \multirow[t]{2}{*}{ AGI } & \multirow{2}{*}{\multicolumn{2}{|c|}{$\begin{array}{l}\text { Gross property tax } \\
\text { contribution to } \\
\text { schools }\end{array}$}} & \multirow{2}{*}{$\begin{array}{c}\text { Total tax } \\
\text { deduction } \\
\text { offset per cent }\end{array}$} & \multicolumn{2}{|c|}{ Net property tax contribution } \\
\hline & & $\%$ of $\mathrm{AGI}$ & & Amt. & $\%$ of $A G I$ \\
\hline 3,500 & $\$ 177$ & $5.06 \%$ & $14 \%$ & $\$ 152$ & $4.34 \%$ \\
\hline 5,000 & 204 & 4.08 & 16 & 172 & 3.44 \\
\hline 6,000 & 220 & 3.67 & 16 & 185 & 3.08 \\
\hline 7,000 & 236 & 3.37 & 17 & 196 & 2.80 \\
\hline 8,000 & 252 & 3.15 & 19 & 204 & 2.55 \\
\hline 9,000 & 274 & 3.04 & 20.60 & 218 & 2.42 \\
\hline 10,000 & 296 & 2.96 & 21.43 & 233 & 2.33 \\
\hline 12,000 & 349 & 2.91 & 21.40 & 274 & 2.28 \\
\hline 15,000 & 408 & 2.72 & 25.10 & 306 & 2.04 \\
\hline 20,000 & 516 & 2.58 & 26.7 & 378 & 1.89 \\
\hline 30,000 & 725 & 2.42 & 28.2 & 521 & 1.74 \\
\hline 35,000 & 816 & 2.33 & 38.8 & 499 & 1.43 \\
\hline 50,000 & 1,074 & 2.15 & 38.8 & 657 & 1.31 \\
\hline 75,000 & 1,354 & 1.81 & 57.7 & 573 & .76 \\
\hline 100,000 & 1,993 & 1.99 & 57.7 & 843 & .84 \\
\hline
\end{tabular}

of the property taxes charged to the landlord being shifted to the renter in the form of higher rent-and the effects of personal income tax deductions require this distinction. See notes 157-61 infra and accompanying text.

121. Taken from Table III-B-6 infra.

122. These data are shown in Table III-B-3 infra. 
From Table III-A-1 a number of important relations become evident. On a net basis on the average, the richer homeowner family can be expected to contribute a smaller portion of its income to elementary and secondary schools than the poorer. To continue to rely on a system of local school financing that operates in this manner is unjust. Moreover, on a net basis user families are not, in general, paying through local property taxes anywhere near the amonnt spent on the education of their children. This seems quite appropriate. The benefits of elementary and secondary education are not limited to the pupil; they spill over to the general comnnunity in reduced-crime rates, reduction in dependency, increased rates of economic growth, a supply of community and national leaders, and an educated electorate. ${ }^{123}$ Focussing upon the "typical user family," it is apparent also from Table III-A-1 that the $\$ 12,000$ AGI homeowner family would make a net contribution of $\$ 274$ through property taxes to elementary and secondary schools im 1972-73; the estimated gross contribution of the same family would be $\$ 349$.

(ii) Relating the predicted property tax burden to the article 16 tax rates. The article 16 self-tax selected for $B$ and $F$ schools for families with $\$ 12,000$ AGI is $\$ 310$. It is assumed that the article 16 tax will be tax deductible at the federal level ${ }^{124}$ but not at the state level. ${ }^{125}$ The value of the federal offset for the $\$ 12,000$ AGI family is estimated to be $19 \% .{ }^{120}$ Therefore, the article 16 tax net contribution for the $\$ 12,000$ AGI family will be $\$ 251$. Note that this is deliberately lower than the $\$ 274$ net contribution that was estimated to be the $\$ 12,000$ AGI homeowner family's $1972-73$ property tax contribution under the present system. There are a nuniber of reasons for selecting a gross tax of $\$ 310$ which yields an estimated net of $\$ 251$ rather than a higher

123. See C. Benson, The Economics of Public Education 30-62 (1968). Conceptually, setting aside separate problems of family wealth differences, an accurate division of the costs between the class of users (and their families) and the general public (taxpayers as a whole) would require the measure of private versus public benefits.

124. See INT. REv. CODE of 1954 , § 164. One potential problem is whether or not the article 16 tax is a "tax"; it could be argued by some to be a form of tuition. However, it is surely in the pattern of a use tax. In any event, it is essential that it be deductible, for otherwise Californians would receive unequal treatment as compared with citizens of other states by opting for what is simply a different form of school fimance.

125. In general, for state income tax purposes, other state taxes are not deductible. There seems no reason to make the article 16 tax an exception. If the net burden is reasonable, further adjustments taking such deduction into account would be unnecessarily complicated.

126. See Table II-B-4 infra. It is assumed that the federal incoune tax rates will remain constant. Note that the marginal federal tax rate is used in estimating the benefit of the deduction, as discussed in section B infra. Note further that the $19 \%$ figure assumes that the family will itemize deductions rather than take the "standard" deduction. 
gross that would yield an estimated net of $\$ 274$. It is expected that the typical family's total contribution to education will go up because of anticipated increases in state taxes under the Act. ${ }^{127}$ The authors also have some concern about renters. Thirty-eight percent of California families are renters ${ }^{128}$ and the percentage of these families with school age children is not known. While the renter data may not be flawless, there are indications that renters of the same AGI class currently make a lesser contribution to education through property taxes, paid indirectly through their rent, than do homeowners. ${ }^{129}$ To some this may indicate that homeowners are paying "too inucl," but the authors' concern for the present is merely to make the burden under the Act similar to that which it is replacing. In one sense, of course, this task is impossible. If the present tax differs in its effects upon owners and renters, a tax with a uniform effect on user families can scarcely provide a precise substitute.

The objective of imposing a similar burden also raises another problem regarding renters. Since renters pay indirectly, it is not clear that they would receive the benefit, at least immediately, of the elimination of local school property taxes that would occur under the Act. ${ }^{130}$ On the other hand, once the influence of wealth differences has been minimized or eliminated, substantially greater burdens on users as opposed to nonusers may be justified by the private benefits they enjoy. Balancing these factors, the article 16 tax was pegged so that it would result in a net contribution at the $\$ 12,000$ AGI level about $10 \%$ lower than the estimated net contribution for sucl families in 1972-73 under the present system.

\section{c. Setting the article 16 tax for $B$ and $F$ schools for all other levels of $A G I$}

The next task was to determine the article 16 tax for $B$ through $F$ schools for families at AGI levels other than $\$ 12,000$. For various reasons the tax tables have been simplified to include only three income classes: below $\$ 3,500 ; \$ 3,500-\$ 12,000$; and, above $\$ 12,000$. While

127. See text accompanying notes 181-86 infra.

128. See Cal. Legislative Analyst, The Distribution of California's Population by Income Categories, June 10, 1970 [hereinafter cited as Analyst's Population Distribution Report].

129. See section B. Compare Table III-B-3 infra with Table IV-2-F infra. While the authors' figures are suspect since they are comparing homeowner families with all renters, note that the most widely cited study of the problem, D. NETZER, Economics OF THE PROPERTY TAX 45-55 (1966), concluded that at incoine levels above the $\$ 2,000$ AGI, homeowners do pay somewhat more than renters in property taxes.

130. Any effort to effect an instant adjustment for the renter through direct subsidy or rent control would do more harm than good. The most promising course is an acceleration of market adjustment through disclosure to renters of the tax reduction in favor of their landlord. 
this causes some policy problems it makes the presentation easier to follow. Thie rates selected for $B$ and $F$ schools are:

\begin{tabular}{ll}
\multicolumn{1}{c}{ AGI } & \multicolumn{1}{c}{ Tax } \\
Under $\$ 3,500$ & $\$ 10$ \\
$\$ 3,500$-less than $\$ 12,000$ & $\$ 10+3.5 \%$ of AGI above $\$ 3,500$ \\
$\$ 12,000$ and above & $\$ 310+4.2 \%$ of AGI above $\$ 12,000$
\end{tabular}

Table III-A-2 illustrates at selected AGI levels the resulting gross tax and the net contribution (in amount and percent).

Table III-A-2

Article 16 tax contributions for $B$ and $F$ schools at various AGI levels

\begin{tabular}{|c|c|c|c|c|c|}
\hline \multirow[t]{2}{*}{ AGI } & \multicolumn{2}{|c|}{$\begin{array}{l}\text { Gross article } 16 \text { tax } \\
\text { contribution }\end{array}$} & \multirow{2}{*}{$\begin{array}{c}\text { Federal } \\
\text { tax } \\
\text { offset }\end{array}$} & \multicolumn{2}{|c|}{$\begin{array}{l}\text { Net article } 16 \text { tax } \\
\text { contribution }\end{array}$} \\
\hline & Amt. & $\%$ of $A G I$ & & Amt. & $\%$ of $\mathrm{AGI}$ \\
\hline$\$ 1,000$ & 10 & 1.0 & 一 & 10 & 1.0 \\
\hline 2,500 & 10 & .4 & - & 10 & .4 \\
\hline 3,500 & 10 & .28 & $14 \%$ & 9 & .26 \\
\hline 4,000 & 27.5 & .69 & 15 & 23 & .57 \\
\hline 5,000 & 62.5 & 1.25 & 16 & 52 & 1.02 \\
\hline 6,000 & 97.5 & 1.63 & 16 & 82 & 1.36 \\
\hline 7,000 & 132.5 & 1.89 & 17 & 110 & 1.57 \\
\hline 8,000 & 167.5 & 2.09 & 19 & 136 & 1.70 \\
\hline 9,000 & 202.5 & 2.25 & 19 & 164 & 1.82 \\
\hline 10,000 & 237.5 & 2.38 & 19 & 192 & 1.92 \\
\hline 12,000 & 210 & 2.58 & 19 & 521 & 2.09 \\
\hline 15,000 & 436 & 2.91 & 22 & 340 & 2.27 \\
\hline 20,000 & 646 & 3.23 & 22 & 504 & 2.52 \\
\hline 25,000 & 856 & 3.42 & 22 & 668 & 2.67 \\
\hline 30,000 & 1,066 & 3.55 & 22 & 831 & 2.77 \\
\hline 35,000 & 1,276 & 3.64 & 32 & 868 & 2.48 \\
\hline 50,000 & 1,906 & 3.81 & 32 & 1,296 & 2.6 \\
\hline 75,000 & 2,956 & 3.94 & 53 & 1,389 & 1.85 \\
\hline 100,000 & 4,006 & 4.01 & 53 & 1,883 & 1.88 \\
\hline
\end{tabular}

The article 16 tax rates above $\$ 12,000$ AGI are here assumed to apply uniformly to all income levels. The need for tax ceilings at higher AGI levels is discussed in a later section of this part of the Article. ${ }^{131}$

The $\mathrm{B}$ and $\mathrm{F}$ school rate structure can be further illustrated by converting the numbers in Table III-B-1 into graphs. Graph III-A-1 shows the gross and net dollar contributions at various AGI levels. Graph III-A-2 shows the gross and net percentage contributions at various AGI levels.

131. See section A-4 infra. 
Graph III-A-1

Gross and net dollar contributions through article 16 tax for $B$ and $F$ schools by AGI ${ }^{132}$

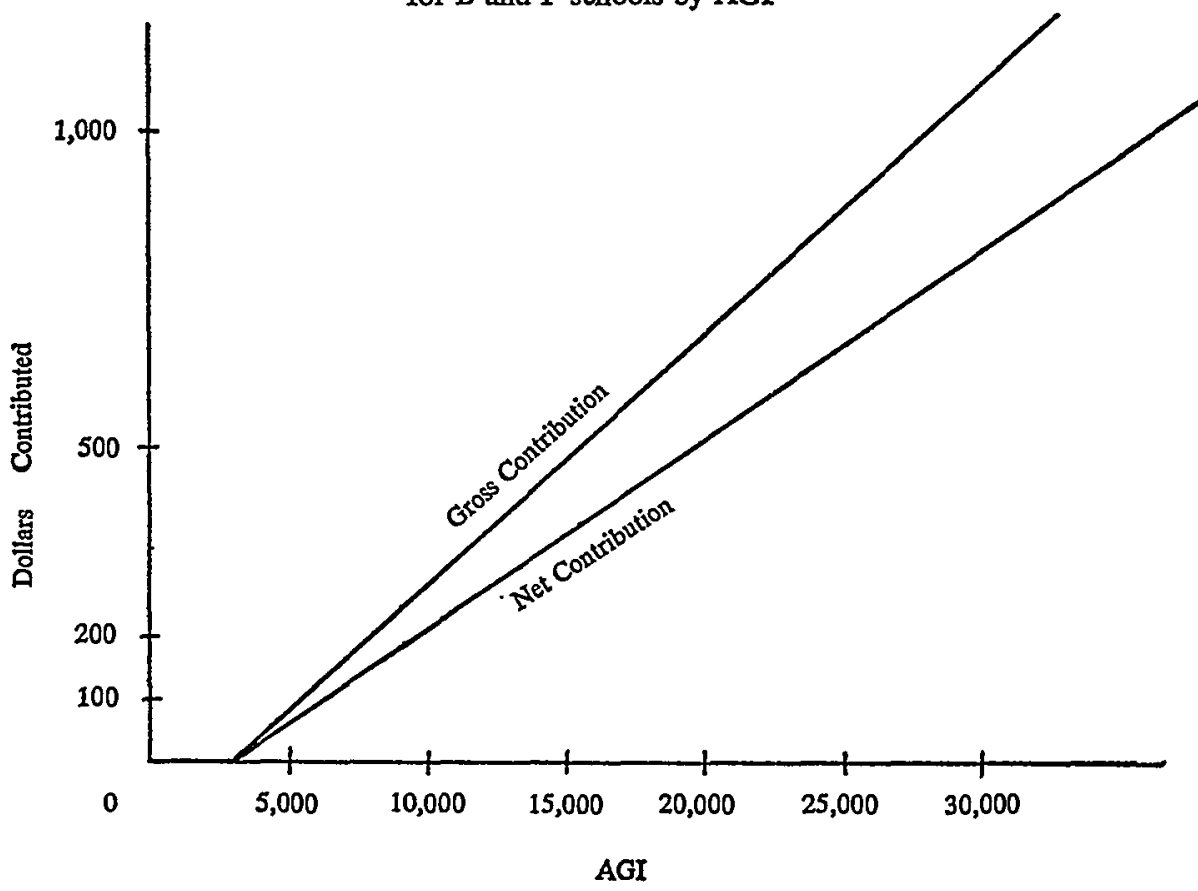

Graph III-A-2

Gross and net percentage contributions to B and F schools, through article $16 \operatorname{tax}^{133}$

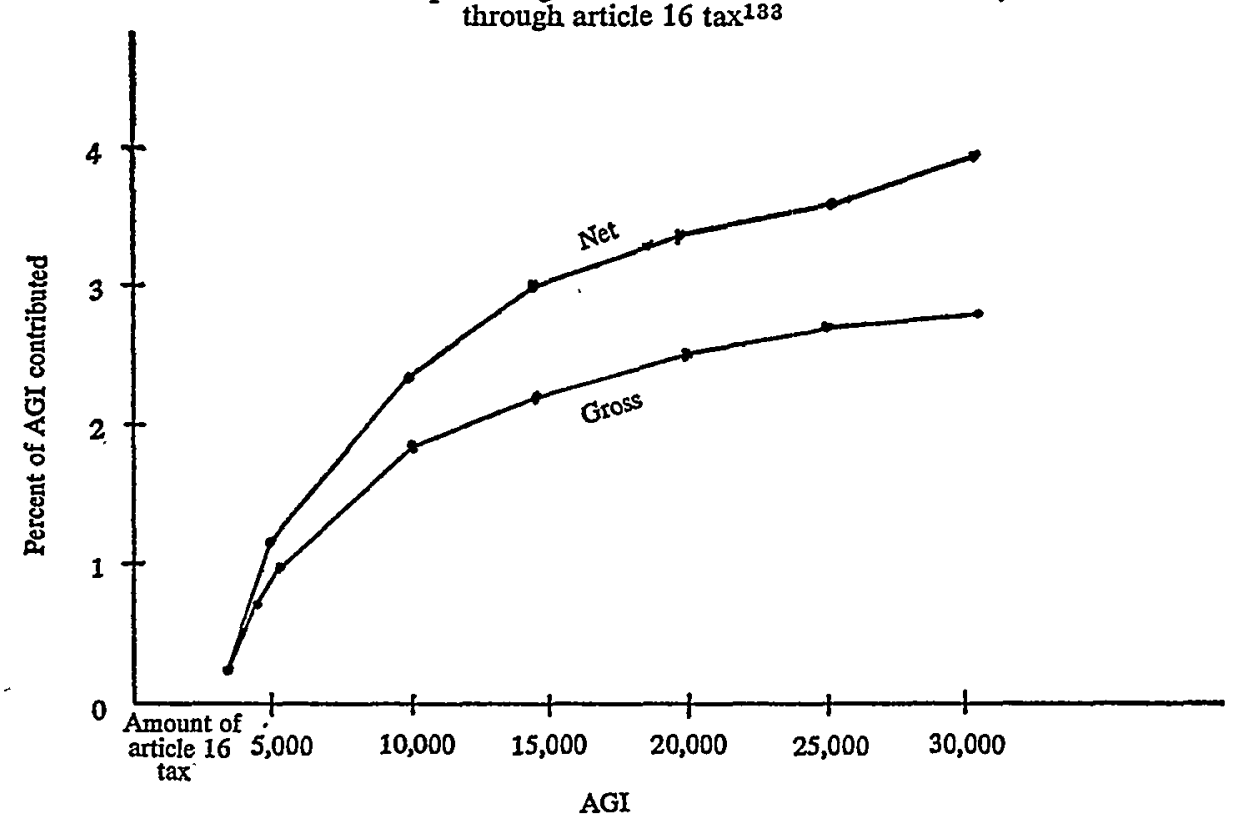

132. Derived from Table III-A-2, cols. $2 \& 5$.

133. Derived from Table III-A-2, cols. $3 \& 6$. 
From Table III-A-2 and Graphs III-A-1 and III-A-2, it will be observed that in three senses as one becoines richer, one pays more: In total dollars; in the percentage of AGI represented by the gross article 16 tax; and, in the percent of AGI represented by the net tax contribution. Because of the fundamental objective of the Act to eliminate the influence of wealth on the spending level of the school chosen by the family for its children-and assuming that the authors' approach to calculating the federal tax deduction benefit is acceptable - the reasons for having the rich pay more in the first and second senses need no further explanation.

The primary basis for the decision to have richer faunilies pay a greater proportion of income on a net basis is the murky concept of marginal utility. ${ }^{134}$ A reasonable economic assumption is that the loss of a dollar of income implies a greater loss of satisfaction for a poor family than a wealthy one. Thus, a dollar taxed from a poor family reduces its level of utihty by more than a dollar taxed from a high imcoine family. This reduction in utility resulting from a loss of a dollar of income is the marginal utility of income. In order to eliminate the influence of wealth, families of different incomes must be taxed im a manner that requires each family to contribute the same proportion of its total utility. Therefore, a net progressive tax rate structure-one where the ratio of net tax contribution to income rises with income-is called for. Requiring a net contribution of $1.02 \%$ of the $\$ 5,000$ AGI family's income may imply that this family is sacrificing the same proportion of its total utility as is a $\$ 20,000$ AGI family which must make a net contribution of $2.52 \%$. Since there are no means of measuring the "true" marginal utility schedules of typical families, it is only possible to provide rates which are illustrative and seem reasonable.

The extremes of Table III-A-2 sliould be noted. Since a $\$ 3,500$ AGI is a standard "poverty" line, it offers a convenient boundary for the lowest rate class. The rates for this class are cheap compared to the education they purchase, but the sacrifice for a poverty family is still significant. Some would, no doubt, prefer not to charge the poor at all. Nevertheless, the authors would prefer to treat the poor as others are treated by requiring them to sacrifice something for their children's education and to sacrifice different amounts to send their children to different categories of schools. Ten dollars has been selected as the

134. Additionally, while all families may itemize tax deductions and hence specifically deduct the article 16 tax for federal income tax purposes, experience shows that for a variety of reasons the poorer the family, the less likely it will file a federal tax return other than on the basis of the standard deduction. This behavior will be further stimulated as the standard declaration is increased. Recent legislation increases this deduction by increments until it reaches $\$ 2,000$ in 1972. INT. REV. CODE of 1954, $\S 141(\mathrm{~b})$. 
minimum required tax for $\mathrm{B}$ and $\mathrm{F}$ schools, if for no other reason than to be able to use $\$ 5, \$ 15$ and $\$ 20$ for the other categories.

Since only one tax bracket has been employed for AGI levels above $\$ 12,000$, the percentage of AGI represented by the family's net contribution eventually begins to fall off above $\$ 30,000$. This could be easily prevented by another tax bracket, but, if it is desirable to kcep the wealthy in the system, this effect must be tolerated. Indeed it must be accentuated by a tax ceiling. ${ }^{135}$

\section{Setting the Tuition Credit Amounts for $A$ and $E, C$ and $G$, and $D$ and $H$ Schools}

The tuition credit amounts for the four classes of schools have been set at $\$ 300$ intervals; thus the entire chart for use in articles 11 and 13 is as follows:

\begin{tabular}{lcccc} 
& A and E & \multicolumn{2}{c}{$\begin{array}{c}\text { Category of school } \\
\text { B and F }\end{array}$ C and G } & D and H \\
$\begin{array}{l}\text { Elementary tuition } \\
\text { Credit level }\end{array}$ & $\$ 600$ & $\$ 900$ & $\$ 1,200$ & $\$ 1,500$ \\
$\begin{array}{l}\text { High school tuition } \\
\text { credit level }\end{array}$ & $\$ 900$ & $\$ 1,200$ & $\$ 1,500$ & $\$ 1,800$
\end{tabular}

The $\$ 300$ intervals represent an increase from one level to the next significant enough that parents will feel that there is a likelihood of increased quality at the higher level. For a class of 30 pupils, the difference amounts to $\$ 9,000$, or more than the classroom teacher earns per year in much of California today. The school should be able to purchase substantial educational benefits for that amount, whether they be im the form of a lower pupil-teacher ratio, higher paid teachers, or new materials and personnel.

The tuition credit levels also represent roughly the range of spending that is predicted for California schools for 1972-73 based upon projections from today's high-and low-spending districts. Three examples illustrate the range of spending im elementary, high school, and unified districts. Consider first Wheatland Elementary District in Yuba County and Hillsborough Elementary District in San Mateo County. In 1968-69 Wheatland was one of the lower spending and poorer elementary districts in California with current expenditures per pupil in ADA of $\$ 499$, whereas Hillsborough was one of the higher spending and richer with current expenditures of $\$ 1,071$ per pupil. If $5 \%$ is added to these amounts to convert to an estimated total expenditure per pupi ${ }^{136}$ and then they are boostcd $41 \%$ based upon an estimate of

135. See text accounpanying notes 131 supra and 144 infra.

136. State Board of Education figures show noncurrent expenditures as only 
the growth in elementary district spending, ${ }^{137}$ the result is a $1972-73$ estimated total spending per pupil of $\$ 738$ in Wheatland and $\$ 1,585$ in Hillsborough. This range pretty well fits with the tuition credit range of $\$ 600$ to $\$ 1,500$ for elementary grades.

Similarly, consider Taft Union High School District in Kern County with current expenditures of $\$ 1,263$ per pupil in 1968-69 and Grant Joint Union High School in Sacramento County with current expenditures of $\$ 725$ per pupil in 1968-69. Adjusting 5\% for noncurrent spending and $36 \%$ for estimated spending growth, ${ }^{138}$ the result is a 1972-73 estinated total spending per pupil of $\$ 1,806$ per pupil in Taft and $\$ 1,037$ per pupil in Grant. This range also fairly well reflects the tuition credit range for high school grades of $\$ 900$ to $\$ 1,800$.

Finally, consider Beverly Hills Unified District in Los Angeles County with current expenditures per pupil in 1968-69 of $\$ 1,232$ and Parher Unified District in Fresno County with current expenditures per pupil in 1968-69 of $\$ 563$. First current expenditures in these districts for elementary and high school pupils were estimated separately, ${ }^{139}$ then a 5\% adjustment for noncurrent expenditures was inade and then the totals were boosted as before, $41 \%$ in the case of elementary pupils and $36 \%$ in the case of high school pupils. This process yielded estimated 1972-73 total spending per pupil in Beverly Hills of $\$ 1,578$ for elementary pupils and $\$ 2,098$ for high school pupils and in Parher of $\$ 833$ and $\$ 1,028$ respectively. ${ }^{140}$ Again these figures are generally representative of the range of spending available under the Model Act.

While uniform dollar intervals between the categories have been selected, increasing or decreasing intervals might have been employed. One rationale for such a policy might be that from one category to the next, equal increases in "true" quality are sought, and this might require accelerating or decelerating the dollar amount between categories.

$2.8 \%$ of total expenditures, although they then additionally show approximately $1.0 \%$ for certain debt service. SELECTEd StaTrSTICS, supra note 112, at 76.

137. The $41 \%$ is based upon the $\$ 900$ tuition credit amount set for B through $F$ elementary schools as compared with present spending of $\$ 640$. See text accompanying notes 111-12 supra.

138. The $36 \%$ is analogous to the elementary school adjustments and is based on the $\$ 1,200$ versus $\$ 880$ figures discussed in the text accompanying notes 111-12 supra.

139. The Beverly Hills calculations were based on the fact that there were 1.41 times as many elementary school pupils as high school and junior college pupils in the district in 1968-69, and the assumption, as before, of $37.5 \%$ more spending on high school as compared with eleinentary school pupils. The Parlier calculations were based on the saine spending assumption, and the enrollment of 3.31 times as many elementary school pupils as high school and junior college pupils in the district in 1968-69. Selected Statistics 84, 90.

140. Because of the problems of the inclusion of junior college students with the high school students, the estimates may be somewhat high as to spending estimates for high school pupils and, in turn, slightly low for elementary school pupils. 
Another might be that higher tuition credit level choices are to be stimulated or discouraged. Note, however, that it is difficult to think about any such policy by concentrating on the tuition credit levels alone; the corresponding tax rates are equally relevant.

\section{Setting the Tax Rates for $A$ and $E, C$ and $G$, and $D$ and $H$ Schools}

The article 16 tax rates for the $A$ and $E, C$ and $G$, and $D$ and $H$ categories of schools were established in two main steps. The appropriate tax rates for $\$ 12,000$ AGI user fannilies were set and these rates then formed a benchmark for fixing the rates for each of the other categories of AGI groups. The final comprehensive tax table for insertion in article 16 is presented in Table III-A-3.

Table III-A-3

Article 16 tax rates

\begin{tabular}{lllll}
\multicolumn{1}{c}{ AGI } & \multicolumn{1}{c}{ A and $\mathrm{E}$} & \multicolumn{1}{c}{ Bax rate by category of school } & \\
$0-\$ 3,500$ & $\$ 5$ & $\$ 10$ & C and & D and $H$ \\
$\$ 3,500-\$ 12,000$ & $\$ 5+2.3 \%$ & $\$ 10+3.5 \%$ & $\$ 15$ & $\$ 20$ \\
& above $\$ 3,500$ & above $\$ 3,500$ & above $\$ 3,500$ & above $\$ 3,500$ \\
$\$ 12,000$ and up & $\$ 200+3.0 \%$ & $\$ 310+4.2 \%$ & $\$ 450+5.8 \%$ & $\$ 610+7.6 \%$ \\
& above $\$ 12,000$ & above $\$ 12,000$ & above $\$ 12,000$ & above $\$ 12,000$
\end{tabular}

A number of other considerations went into this final phase, few of which can be accounted for in a precise inathematical way but, nevertheless, deserve some explanation. Focusing first on the $\$ 12,000$ AGI family, it was important that the change in the tax be steep enough among the different spending categories of schools so that most families of $\$ 12,000$ AGI would not automatically choose the most costly school simply because it represented no significantly increased sacrifice on their part. In short, families should be made to face real economic choices. By the same token the rates should not be so steep as to discourage most from opting for anything but the lower spending levels. The following chart shows the gross tax and net contribution-assuming a $19 \%$ federal tax offset benefit-for the $\$ 12,000$ AGI family for the different categories of schools.

$\begin{array}{lcccc} & \mathrm{A} \text { and } \mathrm{E} & \mathrm{B} \text { and } \mathrm{F} & \mathrm{C} \text { and } \mathrm{G} & \mathrm{D} \text { and } \mathrm{H} \\ \text { Gross tax } & \$ 200 & \$ 310 & \$ 450 & \$ 610 \\ \text { Net contribution } & \$ 162 & \$ 251 & \$ 365 & \$ 494\end{array}$

Note that to shift to a higher tuition credit level school the faunily must each time, on a net basis, further increase its commitment. For example, to go from $A$ and $E$ to $B$ and $F$ means an increased net contribution of $\$ 89$, while to go from $B$ and $F$ to $C$ and $G$ means an increase of $\$ 114$.

After the tax rates for the $\$ 12,000$ AGI family had been established, the rates for other families were determined. This process in- 
volved keeping two principles in mind. First, looking at each tuition credit level separately, the proportion of utility sacrificed by a family should be the same regardless of its income. This was the principle employed in setting the $B$ and $F$ rates for AGI levels other than $\$ 12,000 .^{141}$ Second, the increased burden required to move from one tuition credit level to another must be such that substantially the same economic choice is made by families regardless of AGI. In theory, this might be said to be accomplished if the same utility represented by those added $\$ 89$ given up by the $\$ 12,000$ family in going from $A$ and $E$ to $B$ and $F$ schools was given up by all families in going from $A$ and $E$ to $B$ and $F$ schools, and likewise for each other change. Superimposed on these principles is the need for reasonable balance between the increased net dollars contributed and the increased amount of the tuition credit obtained for those dollars. If the rate increases are not correlated to some degree with the increase in spending, the structure could stimulate some families to select a lower tuition credit level than they might otherwise select and to seek private supplemental education instead of paying an increased article 16 self-tax.

Tables III-A-4, $-5,-6$ present gross tax, federal offset and net contribution data for $A$ and $E, C$ and $G$, and $D$ and $H$ schools in the same format that was used in Table III-A-2 for B and F schools assuming no ceiling on the rates at the upper income bracket. Table III-A-7 presents selected inforination based upon various Tables in this part.

Table III-A-4

Article 16 tax contributions for $A$ and $E$ schools at various AGI levels

\begin{tabular}{|c|c|c|c|c|}
\hline AGI & Gross tax & Fed. tax offset & Net tax & $\begin{array}{l}\text { Net tax as } \\
\% \text { of AGI }\end{array}$ \\
\hline$\$ 1,000$ & $\$ 5$ & - & $\$ 5$ & .5 \\
\hline 2,500 & 5 & - & 5 & .2 \\
\hline 3,500 & 5 & $14 \%$ & 4 & .11 \\
\hline 4,000 & 16.5 & 15 & 14 & .35 \\
\hline 5,000 & 32.5 & 16 & 33 & .66 \\
\hline 6,000 & 62.5 & 16 & 52 & .87 \\
\hline 7,000 & 85.5 & 17 & 71 & 1.01 \\
\hline 8,000 & 108.5 & 19 & 88 & 1.1 \\
\hline 9,000 & 131.5 & 19 & 107 & 1.19 \\
\hline 10,000 & 154.5 & 19 & 125 & 1.25 \\
\hline 12,000 & 200 & 19 & 162 & 1.35 \\
\hline 15,000 & 290 & 22 & 226 & 1.51 \\
\hline 20,000 & 440 & 22 & 343 & 1.71 \\
\hline 25,000 & 590 & 22 & 460 & 1.84 \\
\hline
\end{tabular}

141. See text accompanying note 134 supra. 
[Vol. 59:321

$\begin{array}{rrrrr}30,000 & 740 & 22 & 577 & 1.92 \\ 35,000 & 890 & 32 & 605 & 1.73 \\ 50,000 & 1340 & 32 & 911 & 1.82 \\ 75,000 & 2,090 & 53 & 1,013 & 1.35 \\ 100,000 & 2,840 & 53 & 1,335 & 1.34\end{array}$

Table III-A-5

Contributions for $C$ and $G$ schools at various AGI levels

$\begin{array}{rcccc}\text { AGI } & \text { Gross tax } & \text { Fed. tax offset } & \text { Net tax } & \text { Net tax as } \\ \$ 1,000 & \$ 15 & - & \$ 15 & 1.5 \\ 2,500 & 15 & - & 15 & .6 \\ 3,500 & 15 & 14 \% & 13 & .37 \\ 4,000 & 42.5 & 15 & 33 & .83 \\ 5,000 & 91.5 & 16 & 77 & 1.54 \\ 6,000 & 142.5 & 16 & 113 & 1.97 \\ 7,000 & 193.5 & 17 & 161 & 2.30 \\ 8,000 & 244.5 & 19 & 198 & 2.48 \\ 9,000 & 295.5 & 19 & 239 & 2.63 \\ 10,000 & 346.5 & 19 & 281 & 2.81 \\ 12,000 & 450 & 19 & 365 & 3.04 \\ 15,000 & 624 & 22 & 487 & 3.25 \\ 20,000 & 914 & 22 & 713 & 3.57 \\ 25,000 & 1,205 & 22 & 940 & 3.76 \\ 30,000 & 1,494 & 22 & 1,165 & 3.88 \\ 35,000 & 1,784 & 32 & 1,213 & 3.47 \\ 50,000 & 2,654 & 32 & 1,805 & 3.61 \\ 75,000 & 4,104 & 53 & 1,929 & 2.57 \\ 100,000 & 5,554 & 53 & 2,610 & 2.61\end{array}$

Table III-A-6

Contributions for $\mathrm{D}$ and $\mathrm{H}$ Schools at various $A G I$ levels

$\begin{array}{rccrc}\text { AGI } & \text { Gross tax } & \text { Fed. tax offset } & \text { Net tax } & \text { \% of AGI } \\ 1,000 & \$ 20 & - & \$ 20 & 2.0 \\ 2,500 & 20 & - & 20 & .8 \\ 3,500 & 20 & 14 \% & 17 & .49 \\ 4,000 & 54.5 & 15 & 46 & 1.15 \\ 5,000 & 123.5 & 16 & 104 & 2.08 \\ 6,000 & 192.5 & 16 & 162 & 2.70 \\ 7,000 & 261.5 & 17 & 217 & 3.10 \\ 8,000 & 330.5 & 19 & 263 & 3.35 \\ 9,000 & 399.5 & 19 & 324 & 3.60 \\ 10,000 & 468.5 & 19 & 379 & 3.71 \\ 12,000 & 610 & 19 & 494 & 4.42 \\ 15,000 & 836 & 22 & 652 & 4.35\end{array}$




$\begin{array}{rrcrc}\text { AGI } & \text { Gross tax } & \text { Fed. tax offset } & \text { Net tax } & \begin{array}{c}\text { Net tax as } \\ \text { of AGI }\end{array} \\ \$ 20,000 & \$ 1,218 & 22 \% & \$ 950 & 4.70 \% \\ 25,000 & 1,598 & 22 & 1,246 & 4.98 \\ 30,000 & 1,976 & 22 & 1,543 & 5.14 \\ 35,000 & 2,358 & 32 & 1,603 & 4.58 \\ 50,000 & 3,498 & 32 & 2,379 & 4.76 \\ 75,000 & 5,398 & 53 & 2,537 & 3.38 \\ 100,000 & 7,298 & 53 & 3,430 & 3.43\end{array}$

Table III-A-7

Selected tax data for specific AGI levels based upon article 16 tax rates

Net contribution as $\%$ of

AGI for A and $\mathrm{E}$ schools

Net contribution as \% of AGI for D and $\mathrm{H}$ schools

$\begin{array}{rrrr}\$ 5,000 & \$ 12,000 & \$ 20,000 & \$ 50,000 \\ .66 \% & 1.35 \% & 1.71 \% & 1.82 \% \\ 2.08 \% & 4.12 \% & 4.75 \% & 4.76 \% \\ & & & \\ \$ 19 & \$ 89 & \$ 161 & \$ 385 \\ & & & \\ \$ 27 & \$ 129 & \$ 237 & \$ 574\end{array}$

Increased net dollars to shift from $\mathrm{A}$ and $\mathrm{E}$ to $B$ and $F$

Increased net dollars to shift from $C$ and $G$ $\begin{array}{lllll}\text { to } \mathrm{D} \text { and } \mathrm{H} & \$ 27 & \$ 129 & \$ 237 & \$ 574\end{array}$

Regarding Table III-A-7, observe first that, for both $\mathrm{A}$ and $\mathrm{E}$ and $\mathrm{D}$ and $\mathrm{H}$ schools, families with greater AGI will make a net contribution on a percentage basis greater than will families with less AGI, just as was true for the B through $\mathrm{F}$ schools. This, again, is in recognition of the marginal utility factor. ${ }^{142}$ Note also that in shifting from $A$ and $E$ to $B$ and $F$ and $i m$ shifting from $C$ and $G$ to $D$ and $H$, the greater the AGI, the greater the dollar increase in net contribution required to choose the more expensive school. These greater dollar increases, again, are designed to require families of varying AGI to face a similar choice based upon the extra utility given up by each in moving from one category to another. ${ }^{143}$

Note finally that at all levels the $\$ 50,000$ AGI family must make

142. See text accompanying note 134 supra.

143. Regarding this problem generally, empirical evidence suggests that low income families are more sensitive or responsive to price changes than high income families. Price elasticity of enrollment demand-the percentage change in enrollments resulting from a $1 \%$ change in price-is considered the appropriate measure of responsiveness to price. For example, in a study of higher education in California, a $1 \%$ increase in price reduced enrollments in the lowest income bracket $(\$ 0-\$ 7,599$ in $1967-68)$ by $1.12 \%$; while the drop for the highest imcome bracket $(\$ 19,500$ and over) was only $0.71 \%$ for a $1 \%$ change in price. See Hoenack, Private Demand for Higher Education in California, Dec. 1967, at 52 (unpublished thesis in Umiversity Library, University of California). 
a net contribution of more than $\$ 300$ to get a $\$ 300$ increase in tuition credit; of course if the family has two children in schools under the Act, it buys $\$ 600$ increased tuition credit with less than $\$ 600$. This phenoinenon again poses the question of whether there should be ceilings under the Act both to get the rich into the system and to keep them from having to inake net imcreased contributions in shifting from one spending category to the next which are significantly greater than the total dollars of increased tuition credit they attract by so shifting. Article 16 , section 2 of the FCEA sets out one approach that inight be employed. Because of adıninistrative considerations, it is geared to the gross amount of the article 16 tax paid by the family rather than its net contribution. A more sophisticated device could be employed if the problem were considered serious enough.

The various balancing mechanisms imbedded in these rates and spending levels must be tested in operation. Without experience it cannot be known whether the proper relations have been chosen; in truth, the question of "success" can never be answered with apodictic certainty. Throughout the drafting of the Act we have struggled to remove the influences of family wealtl variations; the concept of equality of sacrifice has dominated the shaping of the chosen rate and spending structure. Assume, lowever, that in practice this structure produces a random distribution of incoine classes among the spending categories. Would this parental beliavior demonstrate that wealth influence is gone and that the required tax sacrifice had been perfectly equalized? By no means, for there would remain the competing hypothesis that inequalities of sacrifice had been offset by reciprocal inequalities of family interest. The poor (or the rich) in fact may care less about education, but may liave been induced to effect a randorn distribution by adequate tax or spending preferences.

Nevertheless, if a random distribution of rich and poor among spending levels is not a logical criterion of equality, it strikes us as a fair objective. The alternative is the egregious presumption that, in some absolute sense, one income class cares more than another. Of this we know no demonstration, nor can we imagine even what phenomena would serve as evidence for such a proposition, especially in a world in which the poor have had no choice. Given such an absence of persuasions in favor of any income class, it seems to us just to aim as nearly as can be for a random distribution of rich and poor.

How nearly such a distribution could be approached is quite unanswerable without experimentation. In all probability it would be necessary to carefully modify rates and/or spending over a series of years to bring the distribution into satisfactory balance. It is most unlikely that the relationships we have developed here in an abstract fashion would provide the optimal behavioral response. 


\section{B. The Gross and Net Burden of the Property Tax for Schools on California Families Projected to 1972-73}

1. Estimating the Average Percentage of Local Property Tax Used to Finance Elementary and Secondary Public Education

Because the property tax is not used solely for school purposes and since it was necessary to start with statewide data, the authors first determined the average proportion of a family's property tax allocable to public elementary and secondary schools. ${ }^{144}$ It should, of course, be remembered that this proportion varies from district to district. This point aside, the calculation is straightforward, and the answer appears reasonably easy to gauge within acceptable ranges.

The California State Board of Equalization reports that the total local property tax levies in the state anounted to $\$ 4,688,986,000$ in 1968-69.145 In an attempt to isolate how much of this total was spent on elementary and secondary education, levies allocable to junior collcge ${ }^{146}$ were subtracted froin the Board's figure labled "school purpose levies." This left $\$ 2,180,480,000$ which includes property levies used for current as well as capital expenditures such as bond principal and interest payments. Hence, an estimated $47 \%$ of the total property tax levies in California is spent for the support of public elementary and secondary schools. It was assuined that the portion of local property taxes used to finance public education would remain substantially unchanged through 1972-73.

\section{Estimating the Amount of School Property Taxes Paid Per Ad- justed Gross Income Group}

In order to estimate school property taxes paid by income group, it was necessary to separate homeowners and renters. The homeowner pays his taxes directly. He is entitled to deduct them on his state ${ }^{147}$ and federal ${ }^{148}$ income tax returns for the year in which the taxes were paid. The computation of the homeowner's average property tax is

144. All the calculations are on a statewide basis even though the Model Act by its terms would apply only to certain counties.

145. Cal. Bd. of Equalization, ANn. Rep. 1968-69, at A-25. The total includes $\$ 119,000,000$ "special assessments"-which include assessments for such purposes as flood control and mosquito abatement.

146. The state publishes an annual report concerning fimancial transactions of all the school districts, including the junior college districts. Cal. ConTroller, ANnual Report of Financial Transactions of Califormi School Districts, 1968-69. The report indicates the amount of local property taxes allocable to separate junior college districts and by independent investigation the amount allocable to junior colleges operated by unified districts in 1968-69 was approximated.

147. Cal. Rev. \& TaX. CODE $\$ 17204$ (West 1970).

148. INT. REv. CODE of $1954, \S 164$. 
simple and rehable. On the other hand, whatever burden the property tax places on the renter is indirect and subtle-requiring complex and contingent assumptions and inferences. Moreover, the statistical data regarding renters is sketchy at best. Finally, the renter is not allowed a deduction for the indirect tax paid in the form of higher rent on either his state or federal return.

For some perspective on the social significance of the owners' and renters' relative contributions to schools, it should be noted that owneroccupied single family dwellings account for $28.60 \%$ of the total assessed valuation in the state. ${ }^{140}$ Rented residential property accounts for $1.9 .65 \%$. Nonresidential property, therefore, accounts for more than half of California's assessed valuation.

\section{a. The homeowner}

Recent studies by the California Legislative Analyst have produced information regarding the average market value of homes by AGI level ${ }^{150}$ and the property tax burden borne by single family owner-occupied homes. ${ }^{151}$ These data allow projection of the homeowner's property tax payments to $1972-73$. Note that $62 \%$ of California families are homeowner families. ${ }^{152}$

In order to estimate the homeowner's property tax for schools in 1972-73, the 1970 average market value of lomes per AGI was first obtained..$^{153}$ These figures were reduced to $22.5 \%$ of market value which represents the effective equalized assessment rate predicted by the California Legslative Analyst. ${ }^{154}$ The resulting values were then increased by $7 \%$ annually to account for appreciation. ${ }^{155}$ The estimated statewide average property tax rate per $\$ 100 \mathrm{~m}$ assessed valuation for 1972-73 is $\$ 11.43 .{ }^{156}$ Based upon this rate a total tax per AGI group was calculated. Based upon the previous calculation of the proportion allocable to education, $47 \%$ of the resulting total figures was

149. Cal. Legislative Analyst, Preliminary Analysis of Gonsalves Initiative, Dec. 5, 1969, Table 1, pt. 2 [hereinafter cited as Analyst's Report on Gonsalves Initiative].

150. Cal. Legislative Analyst, Data Used for 1970 Impact Comparisons, Jan. 16, 1970 [hereinafter cited as Analyst's 1970 Impact Comparisons]. The information was obtained from a study of property tax deductions on income tax returns and a comparison with Bureau of Census data combined with empirical spot checks for accuracy.

151. Analyst's Report on Gonsalves Initiative.

152. Analyst's Population Distribution Report, supra note 128.

153. Analyst's 1970 Impact Comparisons.

154. CaL. Rev. \& TAX. Code $\$ 401$ (West 1970) requires the assessinent ratio to stabilize at 25\% by 1971-72. The Office of the California Legislative Analyst has indicated that the actual assessed value as it works out in practice will always be lower, suggesting that the more accurate figure for our present computations would be $22.5 \%$.

155. Analyst's Report on Gonsalves Initiative 4 . The $7 \%$ increase was compounded annually.

156. Id. 
taken. The resulting numbers represent the estimated gross property tax allocable to schools for 1972-73.157

\section{Table III-B-1}

California homeowner families: calculation of gross contribution to public elementary and secondary schools through the property tax, projected to $1972-73$.

$\begin{array}{rrrrrrr}\text { AGI } & \begin{array}{c}\text { Home market } \\ \text { value 1969-70 }\end{array} & \begin{array}{c}\text { Home assessed } \\ \text { value 1969-70 }\end{array} & \begin{array}{c}\text { Projected } \\ \text { home as- } \\ \text { sessed value } \\ 1972-73\end{array} & \begin{array}{c}\text { Estimated } \\ \text { gross } \\ \text { tostimated property } \\ \text { tax 1972-73 } \\ \text { toperty tax } \\ \text { allocable } \\ \text { to schools } \\ 1972-73\end{array} \\ 3,500 & \$ 12,000 & \$ 2,700 & \$ 3,300 & \$ 377 & \$ 177 \\ 5,000 & 13,800 & 3,105 & 3,800 & 434 & 204 \\ 6,000 & 14,800 & 3,330 & 4,100 & 469 & 220 \\ 7,000 & 15,800 & 3,555 & 4,400 & 503 & 236 \\ 8,000 & 17,000 & 3,825 & 4,700 & 537 & 252 \\ 9,000 & 18,400 & 4,140 & 5,100 & 583 & 274 \\ 10,000 & 19,900 & 4,478 & 5,500 & 629 & 296 . \\ 12,000 & 23,500 & 5,288 & 6,500 & 743 & 349 \\ 15,000 & 27,400 & 6,165 & 7,600 & 869 & 408 \\ 20,000 & 34,800 & 7,830 & 9,600 & 1,097 & 516 \\ 30,000 & 49,100 & 11,048 & 13,500 & 1,543 & 725 \\ 35,000 & 55,000 & 12,375 & 15,200 & 1,737 & 816 \\ 50,000 & 72,500 & 16,313 & 20,000 & 2,286 & 1,074 \\ 75,000 & 91,600 & 20,610 & 25,200 & 2,880 & 1,354 \\ 100,000 & 134,600 & 30,285 & 37,100 & 4,241 & 1,993\end{array}$

\section{b. The renter}

The problems of determining the amount of property tax paid per AGI class are multiplied in dealing with the $38 \%$ of California famihes who are renters. ${ }^{158}$ There is much dispute concerning what each

157. The available data omits married homeowners with AGIs below $\$ 5,000$. However, some estimates in that category may be risked. It seems reasonable to assume that average home values do not continue to drop proportionally as AGI drops below $\$ 5,000$. This is suggested by data showing that single homeowners with a $\$ 3,500$ AGI have homes averaging $\$ 11,900$ in value. Analyst's 1970 . Impact Comparisons. By determining the trend of the relationship between AGI and home value above $\$ 5,000$ AGI one can, perhaps, obtain a general idea of what happens below $\$ 5,000$ of AGI. On this basis, it was estimated that inarried owners with $\$ 3,500$ of AGI owned a hoine with a market value of $\$ 12,000$.

At this AGI level the homeowners group is difficult to analyze with complete confidence. While homeowning families constitute $31 \%$ of the total number of families in the $\$ 0-\$ 5,000$ AGI range, it is probable that these families tend to cluster near the $\$ 5,000$ AGI levels-for which there are separate estimates- giving a skew to our conclusions. Moreover, many low incoine owners are likely to be elderly couples without school age children. Finally, all homeowners in the $\$ 0-\$ 5,000$ range constitute only $6.4 \%$ of the total homeowning families. See Analyst's Population Distribution Report.

158. Id. 
dollar of rent pays for, and no doubt there is variation from community to community in the relative influence of the various rent-affecting factors. Hence, while there is wide agreement that the average renter pays some property tax indirectly through his rent, specification of the actual incidence is extremely difficult.

As far as could be ascertained, there has been no statewide study examining the property tax burden on the California renter. It was therefore necessary to adapt an earlier national study by Netzer, ${ }^{160}$ to California. This study developed a table depicting for each of eight income levels the average percentage of a renter's AGI allocable to the property tax in 1959-60, the results of which are summarized in Table III-B-2, column (1). There were two initial problems in adapting this information to California. First, Netzer's figures represent the national averages, and California unay depart from those averages. Second, the figures are rather old considering the present objective of measuring the impact of the property tax upon the average California renter in 197273. Moreover, and most disconcerting from the standpoint of adaptive accuracy, Netzer's data do not single out families, but include all renters. Therefore, it is quite likely that the figures developed by the authors for renters understate the renting family's property tax burden by a significant degree.

With respect to the uniqueness of California, other data may be einployed in an attempt to make a reasonable correction. Netzer compared total residential property taxes nationally as they related to total national incoine. Data concerning California's total income and total residential property taxes were obtained. A comparison of the two ratios revealed that, on the average, Cahfornia taxes exceeded the national average by $24 \% .^{180}$ This relation seems to be a rcasonable tool

159. D. Netzer, supra note 129.

160. The relationship was expressed in the following way:

Calif. residential prop. tax.

Calif. total individual AGI

U.S. residential prop. tax

U.S. total

Individual AGI

The sources of the California residential property tax were CAL. BD. of EQUnLIzATion, supra note 145, at 7 , and an estimation of distribution of assessed valuation in California by type of property. Cal. Legislative Analyst, Property Tax Relief, 1967 Tax Digest, Fourth Quarter, 20, 23 (1967). California total AGI was obtained from Bureau of CENSUS, U.S. DePT. of COMMERCE, Statistical ABstract of THE UNITED STATES 1963, at 398. The U.S. residential property tax was supplied by D. NeTZER, supra note 129, at 245. The total U.S. AGI appears in BuREAU OF THE CENSUS, supra at 398. 
for measuring California's difference from the naticnal norn at each income level; however, this conclusion assumes that the proportion is uniform at each income level and that it holds for renters even though it was based upon all individuals. In any event, Netzer's percentage figures in column (1) of Table III-B-2 were increased by $24 \%$.

To adjust for the second problem-the obsolescence of data-it was necessary to assess the changes in the average California property tax rates from 1959-60 to 1969-70, then, based on the trend, to project the average rate for 1972-73. The State Board of Equalization in its annual report of 1968-69 estimates the average effective property tax rate for each year from 1958-59 through 1969-70.161 The amount of increase in the average effective property tax rate per $\$ 100$ of value in California between 1959-60 (\$1.82) and 1969-70 (\$2.37) was $30.2 \%$. Therefore, Netzer's rates for renters previously adjusted for California differences were further increased by $30.2 \%$ so as to generate percentages for 1969-70. Over the past five years, the average effective rate has increased by approximately $10 \not$ per year, with the largest increase (14 $\varnothing$ ) coming in 1969-70. The average increase over the past ten years has been $5.5 \not$ per year. The $10 \not$ per year figure seems the more likely trend. Assuming a $10 \varnothing$ per year increase on the $1969-70$ average effective rate of $\$ 2.37$, this would inean an increase of $12.7 \%$ by $1972-73$. Therefore, the previously calculated $1969-70$ rates for each specific income class of renters were increased by another $12.7 \%$ to reflect the estimated average property tax rate per income class in 1972-73. The results appear in column (2) of Table III-B-2.

\section{Table III-B-2}

California renters: estimated renter-paid property taxes projected to $1972-73$

Netzer's national effective

Income class rate of real estate tax paid by renters in 1959-60

$\begin{array}{clc}\text { Less than } \$ 2,000 & 8.49 \% & 15.5 \% \\ \$ 2,000-\$ 3,000 & 3.92 & 7.1 \\ 3,000-4,000 & 2.95 & 5.4 \\ 4,000-5,000 & 2.47 & 4.5 \\ 5,000-7,000 & 2.06 & 3.8 \\ 7,000-10,000 & 1.75 & 3.2 \\ 10,000-15,000 & 1.62 & 3.0 \\ \text { Over } \$ 15,000 & 1.35 & 2.5\end{array}$

161. Cal. Bd. of EQualization, supra note 145, at 7, Table A. The effective rate is based on the property's full market value whereas the assessed rate is based on the assessed valuation which, in California, averages about $22.5 \%$ of the market value. 
In order to make the data consistent with the format used to present homeowner data, rates based upon income ranges had to be converted to rates for specific AGI levels by linear interpolation. ${ }^{102}$ Applying these rates to various AGI levels yields total estimated 1972-73 property tax. As before, $47 \%$ of the total property tax figures was taken to obtain estimates of the average amount which renters would contribute in 1972-73 to public education on the elementary and secondary levels via the property tax, and the results appear in the fourth column of Table III-B-3. The percentage of AGI represented by this contribution has also been calculated, and this is slown in the fifth column of Table III-B-3.

\section{Table III-B-3}

California renters: contribution to elementary and secondary education through the property tax (indirectly paid in rent) projected to $1972-73$

\begin{tabular}{rcccc} 
AGI & \multicolumn{2}{c}{ Gross property tax } & \multicolumn{2}{c}{ Contribution to schools } \\
\% & Amt. & \% of AGI & Amt. & \% of AGI \\
$\$ 1,000$ & $\$ 155$ & $15.5 \%$ & $\$ 73$ & $7.3 \%$ \\
2,500 & 178 & 7.1 & 84 & 3.36 \\
3,500 & 189 & 5.4 & 89 & 2.54 \\
4,000 & 200 & 5.0 & 94 & 2.35 \\
5,000 & 215 & 4.3 & 101 & 2.02 \\
6,000 & 228 & 3.8 & 108 & 1.8 \\
7,000 & 245 & 3.5 & 115 & 1.64 \\
8,000 & 264 & 3.3 & 124 & 1.55 \\
9,000 & 288 & 3.2 & 135 & 1.5 \\
10,000 & 310 & 3.1 & 146 & 1.46 \\
12,000 & 360 & 3.0 & 169 & 1.41 \\
15,000 & 435 & 2.9 & 204 & 1.36 \\
20,000 & 540 & 2.7 & 254 & 1.27 \\
25,000 & 650 & 2.6 & 306 & 1.22 \\
28,000 & 700 & 2.5 & 329 & 1.18
\end{tabular}

162. Note that Netzer's tables deal with averages over a range of income while this study seeks estimates at a particular point of AGI. The salient problem in making this conversion is the existence of differences within income classes that vary among income classes. The problem has not been satisfactorily solved. Moreover, the need to interpolate presents the general problem of range versus points; this is encountered throughout part III. It is dealt with here by assuming that the mid-point of the income range is the specific AGI to which the particular information given for the range corresponds. Information for the specific AGr's appearing in the authors' tables was then calculated using linear interpolation. For example, if the AGI ranges are $\$ 4,000$ to $\$ 5,000$ and $\$ 5,000$ to $\$ 6,000$, then the mid-points are assumed to be $\$ 4,500$ and $\$ 5,500$. If the information for $\$ 5,000$ of AGI is desired, it is calculated as the mean of the information given for each range. A similar approach is used elsewhere throughout part III. 
It should be reemphasized that the renter and homeowner data, while now in the same form, are not comparable-tax offsets asidebecause the data include all renters, single and family, but only family homeowners. As a rough clieck on compatibility, the ratio of Netzer's all-homeowners' burden to his all-renters' burden was compared at various income levels with the ratio of the author's family-lomeowner burden to their updated-Netzer-all-renter burden. Simplifying, the results pointed sliarply to a relative under-estimation of the renter burden. This problem of unreliability plus others forbade any rehance on renter data.

\section{State and Federal Tax Offsets Considered}

If the homeowner itemizes lis tax deductions rather than taking the standard deduction, his net cost of education througl property taxes is generally smaller than his gross contribution because of the tax offsets. This effect becomes particularly significant for homeowners in the upper brackets.

In order to determine the extent of the federal tax offset available to the homeowner through the property tax deduction, it was first necessary to determine the applicable inarginal federal tax rates at various AGI levels. Since the federal tax rate is applied to taxable income, it was necessary to determine the average taxable income for a given AGI. The marginal rate needed is the rate applied to the last increment of taxable income of a given AGI family. Assuming that the property tax is the only variable, it is the last deduction. After determining the narginal rate it is possible to estimate how much a deduction is "worth," in terms of reduced taxes, to a family in a specific AGI class. ${ }^{163}$

Data is available on the total number of joint returns-being most indicative of a family-for a given AGI category and on the total taxable income generated by those same returns. ${ }^{164}$ By dividing one into the other the result will be an estimate of the average taxable income for that AGI. The marginal tax rate on that amount of taxable income can then be easily determined using the 1970 federal tax rate schedule for joint returns. The available federal income tax statistics do not indicate separately for California taxpayers the amount of taxable income generated by joint returns. Although there is reason to suppose that the average taxable income per AGI for all joint returns for California dif-

163. The estimate is probably quite accurate. The federal and state income tax rates themselves do not change rapidly, but by slow progression-in the case of the federal law by $\$ 4,000$ intervals above $\$ 4,000$ of taxable income. Thus, the marginal tax rate will remain the saine over a large spectruin of taxable income.

164. See Internal Revenue Service, U.S. Dep't. Of The Treasury, Statistics OF INCOME-1967, INDIVIDUAL INCOME TAX RETURNS 117 (1970). 
fers somewhat from national data, ${ }^{165}$ the two are measured equal for present purposes.

IRS statistics mdicate that, below $\$ 5,000$ of AGI, joimt returns using the standard deduction outnumbered joint returns itemizing deductions by 4 to 1 ; between $\$ 5,000$ and $\$ 15,000$ of AGI, a little more than half of the joint returns itemized deductions. Above $\$ 15,000$ of AGI, few joint returns used the standard deduction. ${ }^{168}$ Since there is no specific deduction allowed for property taxes if the standard deduction is used, ${ }^{107}$ in such cases there can be no offset. This should be borne in mind in considering the results, since for purposes of determining the federal offset for those deducting property taxes, average taxable income was necessarily calculated exclusively from joint returns itemizing deductions.

The average taxable income per AGI category for those itemizing deductions and the consequent marginal rates appear in Table III-B-4.

\section{Table III-B-4}

Calculations of federal income tax marginal tax rates by AGI class for joint returns.

$\begin{array}{lrrr}\begin{array}{c}\text { AGI class } \\ \text { under } \$ 1,000\end{array} & \begin{array}{c}\text { Average taxable } \\ \text { income }\end{array} & \begin{array}{c}\text { Applicable } \\ \text { marginal rate }\end{array} \\ \$ 1,000 \text { under } \$ 2,000 & \$ & 0 & - \\ \$ 2,000 \text { under } \$ 3,000 & 13 & 14 \% \\ \$ 3,000 \text { under } \$ 4,000 & 207 & 14 \\ \$ 4,000 \text { under } \$ 5,000 & 680 & 14 \\ \$ 5,000 \text { under } \$ 6,000 & 1,373 & 15 \\ \$ \quad 6,000 \text { under } \$ 7,000 & 2,205 & 16 \\ \$ 7,000 \text { under } \$ 8,000 & 3,928 & 16 \\ \$ 8,000 \text { under } \$ 9,000 & 4,434 & 17 \\ \$ 9,000 \text { under } \$ 10,000 & 5,220 & 19 \\ \$ 10,000 \text { under } \$ 15,000 & 7,568 & 19 \\ \$ 15,000 \text { under } \$ 20,000 & 11,930 & 22 \\ \$ 20,000 \text { under } \$ 50,000 & 21,778 & 32 \\ \$ 50,000 \text { under } \$ 100,000 & 54,379 & 53 \\ \$ 100,000 \text { under } \$ 200,000 & 107,105 & 62\end{array}$

165. It is likely, for example, that average medical costs are higher in California.

166. INTERNAL ReVENUE SeRVice, supra note 164 , at 49, Tables $2,3$.

167. INT. REv. CODE of 1954, $\$ \$ 4,141$. The standard deduction is optional and may be taken in lieu of personal deduction. The present standard deduction is the lesser of $\$ 1,000$ or $10 \%$ of AGI. In 1971 it will begin to increase. By 1973 it will rise to a maximum of the lesser of $15 \%$ of AGI or $\$ 2,000$. Undoubtedly this will cause an increasing number of taxpayers, especially those in the lower brackets, to opt for the standard deduction eliminating more deductions for property taxes, and reducing the nunber of offsets. However, for those that continue to itemize the offset these calculations will be substantially accurate. 
The same general procedure was followed in determining the applicable marginal state income tax rates for homeowner families at various AGI levels. Table III-B-5 illustrates those marginal tax rates.

Table III-B-5

Calculation of California income tax marginal rates by AGI level for homeowners filing joimt returns ${ }^{168}$

$\begin{array}{rrrc}\text { AGI } & \text { Taxable income } & \begin{array}{c}\text { Tax after } \\ \text { tax credits }\end{array} & \begin{array}{c}\text { Marginal } \\ \text { rate }\end{array} \\ \$ 1,000 & \$ \quad 0 & \$ \quad 0 & - \\ 2,500 & 0 & 0 & - \\ 3,500 & 1,000 & 0 & - \\ 4,000 & 2,000 & 0 & - \\ 5,000 & 3,000 & 0 & - \\ 6,000 & 4,000 & 0 & - \\ 7,000 & 5,000 & 0 & - \\ 8,000 & 5,510 & 7 & 2 \% \\ 9,000 & 6,360 & 23 & 3 \\ 10,000 & 7,224 & 43 & 3 \\ 12,000 & 9,025 & 97 & 6 \\ 15,000 & 11,644 & 192 & 8 \\ 20,000 & 16,371 & 418 & 10 \\ 30,000 & 22,829 & 852 & 10 \\ 35,000 & 29,145 & 1,411 & 10 \\ 50,000 & 42,759 & 2,771 & 10 \\ 75,000 & 64,693 & 4,964 & 6,581\end{array}$

Since the state deduction for property taxes lowers the state income tax which in turn makes the deduction on the federal return for state income taxes smaller, to add the marginal state and federal rates applicable to a given income class would overstate the combined worth of the offsets. Instead, to calculate the amount of the combined state and federal income tax offset per dollar of property tax, the procedure is to add the relevant federal and state marginal income tax rates and to subtract their product. In other words, if the federal and state marginal tax rates are $t_{s}$ and $t_{s}$, respectively, the offset per dollar of property tax will be: $t_{f}+t_{s}-\left(t_{t} \times t_{8}\right)$. For example, for a $\$ 100,000$ AGI family, the apphicable federal and state marginal rates are $53 \%$ and $10 \%$ respectively. The offset per dollar of local property tax will be $53 \%+10 \%, 5 \%$ or $58 \%$.

Table III-B-6 shows the combined "worth" of the state and federal offsets for various AGI levels based upon the above-described for-

168. Derived from CAL. FRANChise TAX BD., supra note 119, at 43, and Analyst's Population Distribution Report. 
mula and the marginal rates of Tables III-B-4 (after interpolation) and III-B-5. This combined offset rate was applied to the gross contribution amounts from Table III-B-1 yielding the net contribution-in amount and percent-by AGI level through local property taxes to elementary and secondary schools, projected to 1972-73. The conclusions appear in the last two colums of Table III-B-6. No attempt was made to divine what the federal and state legislature might do with the income tax rate structure by 1972-73. It was assuned that the present tax rates would remain applicable.

Note that Table III-B-6 shows the benefit of the offsets even for the lowest income levels. As already noted, many people with less than $\$ 15,000$ of AGI filed a return using the standard deduction, and would therefore not obtain an offset even if they were homeowners. ${ }^{100}$ However, it is reasonable to assume that a large number of those itemizing their deductions had some compelling reason to do so, such as the fact they were homeowners and wanted to deduct property taxes. Therefore, it seems fair for purposes of estimating the net burden to assume that homeowners do deduct property taxes. Moreover, at the $\$ 12,000$ AGI level, whicl is the crucial AGI used in part I, section A, it seems likely that more school-user-homeowner families do specifically deduct property taxes than do not.

Table III-B-6

California homeowner families: gross and net contribution to elementary and secondary education through the property tax projected to $1972-73$

\begin{tabular}{rrrrrr} 
AGI & \multicolumn{2}{c}{$\begin{array}{c}\text { Gross property tax } \\
\text { contribution to } \\
\text { schools } \\
\text { Amt. }\end{array}$} & $\begin{array}{c}\text { Total tax } \\
\text { deduction } \\
\text { offset percent }\end{array}$ & \multicolumn{2}{c}{$\begin{array}{c}\text { Net property tax } \\
\text { contribution }\end{array}$} \\
\$. 3,500 & $\$ 177$ & $5.06 \%$ & 14 & $\$ 152$ & Amt. \\
$5,000$. & 204 & 4.08 & 16 & 172 & $3.44 \%$ \\
6,000 & 220 & 3.67 & 16 & 185 & 3.08 \\
7,000 & 236 & 3.37 & 17 & 196 & 2.80 \\
8,000 & 252 & 3.15 & 19 & 204 & 2.55 \\
9,000 & 274 & 3.04 & 20.6 & 218 & 2.42 \\
10,000 & 296 & 2.96 & 21.4 & 233 & 2.33 \\
12,000 & 349 & 2.91 & 21.4 & 274 & 2.28 \\
15,000 & 408 & 2.72 & 25.1 & 306 & 2.04 \\
20,000 & 516 & 2.58 & 26.7 & 378 & 1.89 \\
30,000 & 725 & 2.42 & 28.2 & 521 & 1.74 \\
35,000 & 816 & 2.33 & 38.8 & 499 & 1.43 \\
50,000 & 1,074 & 2.15 & 38.8 & 657 & 1.31 \\
75,000 & 1,354 & 1.81 & 57.7 & 573 & .76 \\
100,000 & 1,993 & 1.99 & 57.7 & 843 & .84 \\
\hline
\end{tabular}

169. See text accoinpanying note 167 supra. 


\section{The Cost and Revenue Dimensions}

\section{Cost Evaluation}

Because the choices available to families would affect the amount of government moneys spent for their benefit, the prospective total cost of education would involve a prediction-probably based upon experiinentation - of the behavior patterns of families of different incomes. Two factors subject to family choice would affect the cost: The total number of children that will attend schools under the Act, and the portion of such number that will be sent to each of the four tuition credit categories.

Since tuition for $\mathrm{B}$ and $\mathrm{F}$ schools was aimed at the statewide spending average, if the average family chooses B and F schools, and if there is no important change in enrollment in state funded schools, then the state could expect its education budget to remain generally what it would otherwise have been. However, this may not be the enrollment pattern. The Model Act might draw increased numbers of students into schools receiving state money. The most obvious and probably the most important source of a potential increase is the $8 \%$ of California pupils now attending nonpublic schools. ${ }^{170}$ This percentage would be considerably higher in the urban areas most appropriate for experimentation. A major question is whether all or many Catholic schools would elect to become private providers under the Act. Moreover, the Act could stimulate imcreased immigration to California, provide the kinds of choices that would keep more high school students froin becoming "dropouts" (either day-by-day or permanently), cause more widespread participation in kindergarten, and conceivably increase the birth rate in certain kinds of families.

On the other hand, if tax and spending levels are not carefully set, the Act could stimulate a decrease in enrollment in publicly fimanced schools. With local school property taxes removed, some families desiring private education outside the Act for their children might decide that they could for the first time afford to pay private school tuition. Rich families currently using the public schools might find an increased financial burden under the Act such that they would opt for private schools outside the system. Recall, however, that the article 16 tax will be deductible in calculating the federal income tax; tuition will not be. ${ }^{171}$

170. Bureau of Census, U.S. Dep't of Commerce, Statistical Abstract of THE UNITED States 1970.

171. Gifts to wholly private schools which qualify under INT. REv. CODE of 1954, \& 501(c)(3) are deductible. It is possible that such schools could have lower than full cost tuition and put strong pressure for gifts on families whose children attend, thereby in a sense making tuition deductible. Indeed, this form of federal aid to private schools may be said to be occurring today througl Sunday giving-in the case of parochial scliools-and alumni campaigns-in the case of private schools. 
As for the distribution of pupils among spending categories, it is not expected that a disproportionate number of families will choose $D$ and $\mathrm{H}$ schools. There are forces that might push families in that direction. These include the growth of educational consumerism and its influence upon ideology about the importance of school, the fear of later reprisals from one's children, keeping up with the Joneses, and the novelty for the poor of being able to buy government services. Nonetheless, the varying needs of children, the steepness of the rates, thriftiness, and other factors should counterbalance such stimuli to some imponderable extent.

Similarly, a preponderance of families will probably not choose to send their children to $\mathrm{A}$ or $\mathrm{E}$ schools. The mass of individual family decisions is not likely to commit relatively fewer resources to education than are committed presently by the choices of school districts. Families hiving in what are presently poor districts may very well choose to upgrade spending at a rate which exceeds any diminution of the high spending in formerly rich districts. The enrollment patterns the authors would prefer have been described, ${ }^{172}$ but prediction is difficult. It is expected that the tax rates and spending levels established in the Act would be adjusted if the enrollment pattern produced significant separation by income class.

The basis for cost estimates are two separate and inconsistent sets of figures. The first is a prediction of 1972-73 public school enrollment from the California Department of Finance which, of course, assumes the continuance of the present public school systein. It estimates a 1972-73 enrollment in grades kindergarten through eight of $3,181,700$ and in grades $9-12$ of $1,359,600$ for a total of $4,541,300$ pupils. ${ }^{173}$ Note the anticipated decrease in public school attendance as compared with 1968-69 when California ADA was 4,580,000 kindergarten through twelfth grade-3,190,000 ADA in grades kindergarten through eight and $1,390,000 \mathrm{ADA}$ in grades nine through twelve. ${ }^{174}$ The second estimate is not specifically an enrollment prediction but a forecast of the number of school age children in California in 1972-73 from the Population Research Unit of the State Department of Finance. ${ }^{175}$ This is possibly a more useful set of fignres since it includes children who would, in the present scheme of things, be attending private schools. This approach yields one estimate of inaximum attendance in schools under the Act: 3,595,000 children ages 5-13, assigned here to grades kindergarten through eight, and 1,974,000 children ages

172. See text accompanying note 143 supra.

173. Population Research Unit, Cal. Dep't of Finance, California populaTION, 1969, at 10 (1970).

174. See Selected Statistics, supra note 112 , at 7, Table I-3 \& 75, Table IV-5.

175. See note 172 supra. 
14-18, assigned here to grades nine through twelve, for a total of $5,569,000$ pupils. Note that these two estimates vary by more than one million pupils, more than half of whom are in the upper grade age group. Tables III-C- 1 and -2 are based respectively upon these two enrollment projections. They set out estimated costs of elementary and secondary schools given various polarized-and highly unrealistic-school choice behavior patterns; namely, that all children attend alternatively each of the four tuition credit level schools. They also assume that the system is imposed statewide which is radically contrary to both expectation and recommendation. ${ }^{178}$

Table III-C-1

Family Choice in Education Act

Estimated cost range 1972-73

(Attendance based on projected present public school attendance)

Cost (in millions) assuming all pupils attend each category of schools $A$ and $E \quad B$ and $F$ and $G \quad D$ and $H$

Elementary pupils

High school pupils

\begin{tabular}{|c|c|c|c|}
\hline $\begin{array}{r}\$ 1,909 \\
1,224\end{array}$ & $\begin{array}{r}\$ 2,864 \\
1,632\end{array}$ & $\begin{array}{r}\$ 3,818 \\
2,039\end{array}$ & $\begin{array}{r}\$ 4,773 \\
2,447\end{array}$ \\
\hline $\begin{array}{c}3,133 \\
\text { minimum) }\end{array}$ & 4,496 & 5,857 & $\begin{array}{c}7,220 \\
\text { (inaximum) }\end{array}$ \\
\hline
\end{tabular}

Table III-C-2

Family Choice in Education Act

Estimated cost range 1972-73

(Attendance: based on estimated

5-18 year-old population)

Cost (in millions) assuming all pupils attend each category of schools
$A$ and $E$
$B$ and $F$
$\mathrm{C}$ and $\mathrm{G}$
$D$ and $H$

Ages $5-13$

Ages $14-18$

Total cost

\begin{tabular}{|c|}
\hline $\begin{array}{r}\$ 2,157 \\
1,777\end{array}$ \\
\hline $\begin{array}{c}3,934 \\
\text { minimum }\end{array}$ \\
\hline
\end{tabular}

\begin{tabular}{rr}
$\$ 4,314$ & $\begin{array}{r}\$ 5,393 \\
2,961\end{array}$ \\
& $\begin{array}{c}8,553 \\
\text { (maximum }\end{array}$ \\
\hline
\end{tabular}

The theoretical budget range for a statewide system, then, is from $\$ 3$ to $\$ 9$ billion. The practical range seems roughly froin $\$ 4.5$ to $\$ 7$ billion. The actual range must take into consideration the add-ons permitted under the Model Act which might add another 3 or $4 \%$ to the total. ${ }^{177}$ Also not considered are the costs of the state administra-

176. See FCEA art. 3.

177. See id. art. 7, § 4 . 
tive apparatus. The dramatic amount attending even the practical range-perhaps $\$ 2.5$ billion-makes the revenue side of the problem impressive, reinforcing the argument for large scale and long term experimentation. Even in advance of experimentation a serious effort should be made to poll parents on the course they would expect to follow if given such an opportunty.

So as to have a target figure to work with in speaking about revenues, the assuinption is made that the cost of elementary and secondary education under the Act in 1972-73 would be $\$ 5$ billion. This in fact would be the cost-even under a statewide FCEA-if families on the average were to choose schools with $\$ 900$ and $\$ 1,200$ tuition levels for elementary and high school pupils, respectively-B and F schoolsand the differing cost estimates shown in Tables III-C-1 and -2 arising from the conflicting enrollment estimates were arbitrarily split. Five billion dollars assumes an increase in attendance im publicly funded scliools which would cost $\$ 500$ milhon more than the $\$ 4.5$ billion that would be estimated if the State Finance Department's attendance predictions were used. ${ }^{178}$

\section{Revenue Evaluation}

The potential sources of the $\$ 5$ billion must be considered. Generally, the sources are the article 16 tax and general state revenues. State revenues might include federal funds either from general federal revenue sharing programs or specific federal aid to education programs. However, for purposes of this section the role of the federal government is ignored and only the tax effort Cahfornia would have to make to raise all the funds itself is considered. Moreover, it is possible that the federal government might elect either to bypass the state and provide supplemental compensatory vouchers to educationally needy pupils or to direct the flow of its money to specific schools.

The proceeds of the article 16 tax are difficult to predict. Using one recent study of the distribution of families by AGI class combined with estimates of the number of families with school age children-and assuming no leakage to schools outside the system-a primitive forecast of article 16 revenues can be made under varying behavior patterns. ${ }^{170}$ This approach yields estimates of $\$ 600$ milhon assuming all families choose A and E schools, $\$ 900$ inillion if all choose $B$ and $F$ scliools, $\$ 1.3$ billion if all choose $\mathrm{C}$ and $\mathrm{G}$ schools and $\$ 1.7$ billion if all choose $\mathrm{D}$ and $\mathrm{H}$ schools. These figures should be reduced to the

178. It is assumed that the State Finance Department has not allowed for the potential dramatic impact of widespread closing of private schools and, conversely, that it has not allowed for the possibly dramatic impact of substantial aid to private schools.

179. See Analyst's Population Distribution Report. 
extent that pupils enroll in wholly private schools. Note that the higher the tuition credit category, the greater the gap between the amount raised by the article 16 tax and the cost of the program. The more that individual non-rich families spend for education, the more society is committed to spend for education.

Notice also that the article 16 tax will generate less revenue than the present local property tax. In 1967-68 the local property tax brought in more than $\$ 2$ billion for elementary and secondary schools. ${ }^{180}$ Given the $\$ 5$ billion revenue need and the $\$ 900$ million in revenue accruing from the article 16 tax-under the $\mathrm{B}$ and $\mathrm{F}$ mean choice assumption-more than $\$ 4$ billion in general state revenues would be needed under the Act. This exceeds the amount that would be needed from state sources under the present system.

Where would this $\$ 4$ billion plus in state revenues come from? In 1967-68 the state revenue for elementary and secondary education was just short of $\$ 1-1 / 2$ billion. ${ }^{181}$ More revenue from the same tax rates would be expected in 1972-73. The state general fund gets most of its revenue from sales and use taxes, personal income taxes and corporate and financial franchise and imcome taxes. As personal and corporate income rise, revenue will rise. If education continues to obtain the same percentage of the general fund as it does today, then probably more than $\$ 1-1 / 2$ billion would be available from the same state sources in 197273. Moreover, there will be a natural increase in personal income and corporate tax collections by virtue of the end of local property taxes for schools and the consequent loss of the deduction for such payments. This rise, however, we would expect to amount to less than $\$ 100$ million. ${ }^{182}$

Clearly new state level taxes or increases in the rates of existing state taxes-or federal funds-will be needed. One regressive possibility is a statewide property tax. The Statewide Council on LongRange School Finance Planning estimates that a uniform statewide property tax of $\$ 3.75$ on all property would generate $\$ 2,2$ billion

180. Selected Statistics, supra note 112, at 19.

181. Id.

182. "Residential property" for purposes of the property tax consists of roughly $60 \%$ owner-occupied homes and $40 \%$ rented dwellings. The increase in taxes paid by owners of rental units is imponderable; there is no available estimate of their marginal tax rates since some are corporations and some individuals. For the $60 \%$ the Analyst's Report on Gonsalves Initiative has estimated $\$ 2,006$ million from the property tax in 1972-73. Id. Table II. The portion of this amount spent on schools is about $\$ 943$ million (47\%). Average AGI for all California taxpayers in 1968 was $\$ 10,676$. CAL. FrANCHISE TAX BD., supra note 119, at 8 . A $6 \%$ yearly increase yields a $\$ 13,500$ average AGI in 1972. The present marginal income tax rate for this AGI is $4 \%$. Applied to the school property tax figure it yields about $\$ 38$ million. The margmal rates on the incomes of the owners of the $40 \%$ rental units should tend to be higher. 
in 1971-72. ${ }^{183}$ If a school property tax were retained, at least it should be limited to nonresidential property. Such property accounts for over half the assessed valuation in the state. ${ }^{184}$ Exemption of residential property would cut the estimate of revenues raised to something over $\$ 1$ billion, perhaps $\$ 1.25$ billion in 1972-73. Assuming such a modification, perhaps the $\$ 3.75$ rate is too low. In unified districts in 1968-69 nearly half the districts had total school tax rates of between $\$ 4$ and $\$ 5.50 . .^{185}$ In Los Angeles, by far the largest school district in the state, the tax rate-setting aside junior college levies-was $\$ 4.24$ in 1968-69.188 A statewide property tax on nonresidential property of at least $\$ 4.50$ could be considered.

Ultimately, increases in the rates of other state taxes will probably be required unless there is an increase in the proportion of state revenue committed to elementary and secondary education. This is unlikely to occur to any substantial degree unless the federal government takes over a large portion of existing state costs in the health or welfare fields for example. Assuming that state taxes are to be increased, they should not be regressive.

\section{EPILOGUE}

The haggard reader may doubt the net benefit of the effort represented in this Article. Ultimately the apology is that complex policy changes should not be debated as abstractions. It is proper that society be flogged for its prejudice against the unfauniliar, but only as the unfamiliar becomes specific. Those who would debate heresy should first try their hand at drafting the Heretic's Internal Revenue Code (West, St. Paul, 1984). Thereafter, if the critic still inquires why the author created such a thing, at least he can respond: because it was not there.

183. See memo from Wayne M. Burnette, Chairman Statewide Council on LongRange School Finance Planning to State Board of Education, Feb. 11, 1971.

184. Analyst's Report on Gonsalves Initiative.

185. Selected Statistics, supra note 112, at 29, Table III-14.

186. Id. at 43, Table III-16. See also id. at 91, Table IV-11. 